ФЕДЕРАЛЬНОЕ ГОСУДАРСТВЕННОЕ БЮДЖЕТНОЕ ОБРАЗОВАТЕЛЬНОЕ УЧРЕЖДЕНИЕ ВЫСШЕГО ОБРАЗОВАНИЯ «КУРСКИЙ ГОСУДАРСТВЕННЫЙ МЕДИЦИНСКИЙ УНИВЕРСИТЕТ МИНИСТЕРСТВА ЗДРАВООХРАНЕНИЯ РОССИЙСКОЙ ФЕДЕРАЦИИ

НИИ Экспериметнальной медицины

НИИ Физиологии

\title{
ХИРУРГИЯ И ОНКОЛОГИЯ: ЭКСПЕРИМЕНТ И КЛИНИКА
}

Сборник научных трудов

и материалов Научно-практической конференции с международным участием «Эксперимент в хирургии и онкологии»

Курск, КГМУ, 23 сентября 2019 г. 
ФЕДЕРАЛЬНОЕ ГОСУДАРСТВЕННОЕ БЮДЖЕТНОЕ ОБРАЗОВАТЕЛЬНОЕ УЧРЕЖДЕНИЕ

ВЫСШЕГО ОБРАЗОВАНИЯ «КУРСКИЙ ГОСУДАРСТВЕННЫЙ МЕДИЦИНСКИЙ

УНИВЕРСИТЕТ» МИНИСТЕРСТВА ЗДРАВООХРАНЕНИЯ РОССИЙСКОЙ ФЕДЕРАЦИИ

НИИ Экспериментальной медицины

НИИ Физиологии

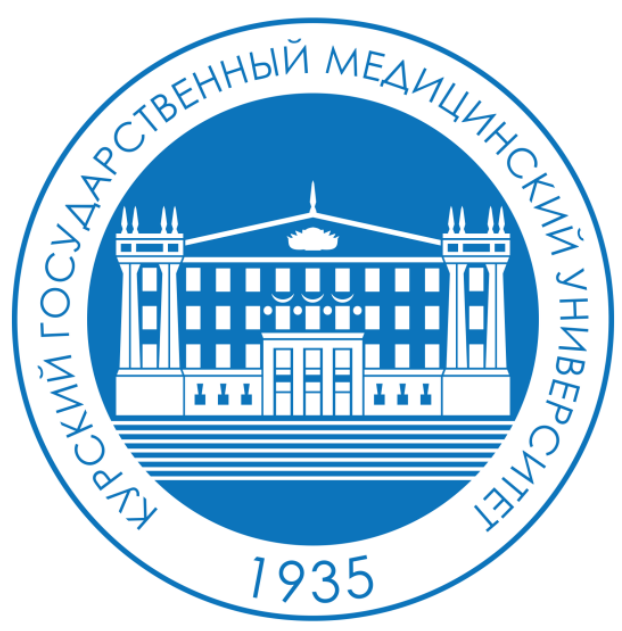

\section{ХИРУРГИЯ И ОНКОЛОГИЯ:}

\section{ЭКСПЕРИМЕНТ И КЛИНИКА}

Сборник научных трудов и материалов Научнопрактической конференции с международным участием «Эксперимент в хирургии и онкологии»
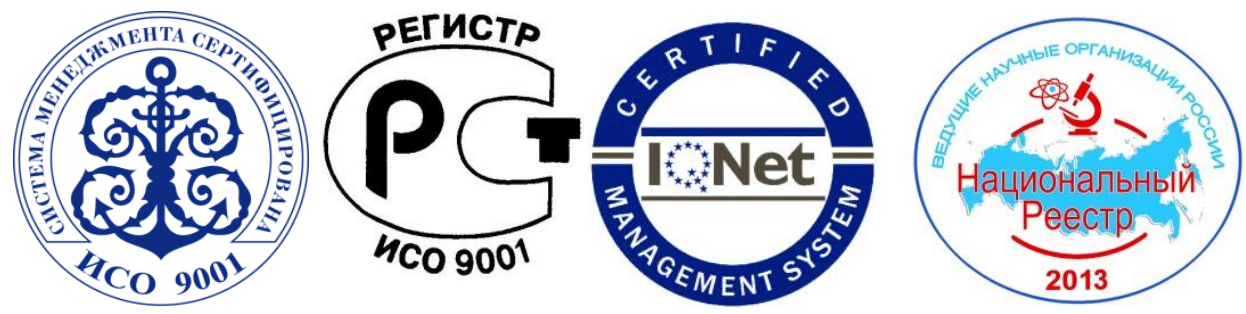
УДК 617:616-006-092.9(063)

ББК 54.5:55.6я43

$\mathrm{X} 50$

Хирургия и онкология: эксперимент и клиника : сборник научных трудов и материалов научно-практической конференции с международным участием «Эксперимент в хирургии и онкологии» (Курск, 23 сентября 2019 г.) / Курский гос. мед. ун-т, НИИ экспериментальной медицины, НИИ фризиологии. - Курск : КГМУ, 2019. $-75 \mathrm{c}$.

ISBN 978-5-9500165-0-9

DOI 10.21626/cb.19.surgeryexperiment

ФГБОУ ВАО КГМУ Минздрава России (

ООО «МедТестИнфро» (C)

Коллектив авторов (C) 


\section{Оглавление}

ПРОГРАММА КОНФЕРЕНЦИИ

АУТОВЕНОЗНЫЕ РЕКОНСТРУКЦИИ АОРТО-ПОДВЗДОШНОГО СЕГМЕНТА У ПАЦИЕНТОВ С ВЫСОКИМ РИСКОМ ИНФЕКЦИОННЫХ ОСЛОЖНЕНИЙ ЛЫЗИКОВ А.А.

ВИРУСНЫЙ ГЕПАТИТ А И ПРОБЛЕМЫ ВАКЦИНОПРОФИЛАКТИКИ ЮСУПОВ Ш.Ш., МатНаЗарОва Г.С., Рахманова Ж.А., Жумамуродов С.Т.

ВЛИЯНИЕ ВОДОРОДНОГО ПОКАЗАТЕЛЯ НА РЕЗУЛЬТАТЫ ЛЕЧЕНИЯ ИНФИЦИРОВАННЫХ РАН НА ФОНЕ ХВН С ПРИМЕНЕНИЕМ БАКТЕРИАЛЬНОЙ ЦЕЛЛЮЛОЗЫ В ЭКСПЕРИМЕНТЕ И КЛИНИКЕ ВИННИК Ю.С. ${ }^{1}$, Шишацкая Е.И.3, Тюхтева Н.М. ${ }^{1}$, Захарченко А.А. ${ }^{1,2}$, Соловьева Н.С. ${ }^{1}$, Шидловский И.П. ${ }^{3}$........14 ГИСТЕРОСКОПИЧЕСКАЯ И МОРФОЛОГИЧЕСКАЯ ОЦЕНКА ВНУТРИМАТОЧНОЙ ПАТОЛОГИИ В ВОЗРАСТНОМ АСПЕКТЕ Колесникова И. О., Сулима А. Н., Давыдова А. А. .17

ЗНАЧЕНИЕ СОВРЕМЕННОГО КОМПЛЕКСНОГО УЛЬТРАЗВУКОВОГО ИССЛЕДОВАНИЯ В ДИАГНОСТИКЕ ОЧАГОВЫХ ОБРАЗОВАНИЙ ЩИТОВИДНОЙ ЖЕЛЕЗЫ ХУШНаЗарОВ Х. Х.

ИЗМЕРЕНИЕ ФИЗИКО-МЕХАНИЧЕСКИХ ХАРАКТЕРИСТИК МЕДИЦИНСКИХ ИЗДЕЛИЙ ДЛЯ ОЦЕНКИ ИХ МАНИПУЛЯЦИОННЫХ СВОЙСТВ Наимзада М.Д.З., Липатов В.А.

ИЗУЧЕНИЕ ВЛИЯНИЯ РАЗЛИЧНЫХ ОБРАЗЦОВ ГЕМОСТАТИЧЕСКИХ ИМПЛАНТОВ НА СВЕРТЫВАЕМОСТЬ КРОВИ В ЭКСПЕРИМЕНТЕ IN VITRO ЛИПатов В.А.(1,2), Сотников К.А.(3), Косоголов М.В.(1), Писковитина С.Г.(1), Гладнева С.Ю.(1), Пучкова Е.Л.(1), Шалаев М.А.(1)

ИЗУЧЕНИЕ ВЛИЯНИЯ РАЗЛИЧНЫХ ОБРАЗЦОВ ГЕМОСТАТИЧЕСКИХ ИМПЛАНТОВ НА ТКАНИ В ЭКСПЕРИМЕTE IN VIVO Гладнева С.Ю., Писковитина С.Г., Косоголов М.В., Драговоз И.С., Пучкова Е.Л., Шалаев М.А., Липатов В.А.

ИННОВАЦИОННЫЕ ТЕХНОЛОГИИ В ЛЕЧЕНИИ ОСТРОГО АППЕНДИЦИТА У БЕРЕМЕННЫХ ПРТРаШЕНКО И.И.

ИССЛЕДОВАНИЕ ВЛИЯНИЯ ГЕМОСТАТИЧЕСКИХ ИМПЛАНТОВ НА ПРОДОЛЖИТЕЛЬНОСТЬ КРОВОТЕЧЕНИЯ В ЭКСПЕРИМЕНТЕ IN VIVO ЛИПатов В.А., ПисковИтИна С.Г., КосогоЛов М.В., Гладнева С.Ю.

ИССЛЕДОВАНИЕ РЕАКЦИИ ТКАНЕЙ ПЕЧЕНИ НА НОВЫЕ ОБРАЗЦЫ ПОЛИМЕРНЫХ КРОВООСТАНАВЛИВАЮЩИХ МАТЕРИАЛОВ ЛИПатов В.А., Лазаренко С.В., Северинов Д.А. 34 КОРРЕКЦИЯ СИНДРОМА ЭНТЕРАЛЬНОЙ НЕДОСТАТОЧНОСТИ В КОМПЛЕКСНОМ ЛЕЧЕНИИ БОЛЬНЫХ С ПЕРИТОНИТОМ Ильченко Ф. Н., Гончарук В. А., Гривенко С. Г.

МЕДИЦИНСКАЯ ЭТИКА КАК ОСНОВА ВРАЧЕБНОЙ ПРАКТИКИ В.Ф.ВОЙНО-ЯСЕНЕЦКОГО ГУРЕЕВа А.

В., Авдеева Е. В.

МИНИИНВАЗИВНАЯ ХИРУРГИЯ В КОМПЛЕКСНОМ ЛЕЧЕНИИ АБСЦЕССОВ ПЕЧЕНИ ГРИГОРЬЕВ С.Н., Бондарев Г.А., Григорьев Н.Н., Бобровская Е.А., Кононенко К.В.

НАУЧНЫЕ ИССЛЕДОВАНИЯ В ОБЛАСТИ МЕДСЕСТРИНСКОГО ДЕЛА СаЛИХОДЖаеВа Р.К.

ОПТИМИЗАЦИЯ ВЕНТРАЛЬНОГО АУТОКОСТНОГО СПОНДИЛОДЕЗА В ХИРУРГИЧЕСКОМ ЛЕЧЕНИИ НЕСПЕЦИФИЧЕСКИХ СПОНДИЛОДИСЦИТОВ ГОНчарОВ М.Ю.1, ЛЕВчИК Е.Ю.2

ОПЫТ ПОЛУЧЕНИЯ ПРЕЦИПИТИРУЮЩИХ СЫВОРОТОК ДЛЯ ИСПОЛЬЗОВАНИЯ В СУДЕБНОМЕДИЦИНСКОЙ ПРАКТИКЕ ЧОрИЕВ Б.А., БахрИЕВ И.И.

ОСОБЕННОСТИ ЭПИДЕМИОЛОГИИ ЗЛОКАЧЕСТВЕННЫХ НОВООБРАЗОВАНИЙ ШУКЕЛаЙТЬ С.П. (1), Семынина Н.М. (2), Дрошнева Т.Н. (2), Панина О.А. (2), Матасова Ю.А. (2) 
ПРОГНОЗИРОВАНИЕ СКЛОННОСТИ К СПАЕЧНОМУ ПРОЦЕССУ У ДЕТЕЙ ПОСЛЕ ХИРУРГИЧЕСКИХ ВМЕШАТЕЛЬСТВ БердИев Э.А., Турабаева З.К.

ПРОФИЛАКТИКА ГНОЙО-СЕПТИЧЕСКИХ ОСЛОЖНЕНИЙ В ПОСЛЕРОДОВОМ ПЕРИОДЕ МУМИНОВО H.X.

РОЛЬ И ПРИМЕНЕНИЕ СОВРЕМЕННОЙ УЛЬТРАЗВУКОВОЙ ДИАГНОСТИКИ УЗЛОВЫХ ОБРАЗОВАНИЙ ЩИТОВИДНОЙ ЖЕЛЕЗЫ МамадалИева Я.М., ХУшназаров Х. Х. .59

СРАВНЕНИЕ КАЧЕСТВА ЖИЗНИ ПАЦИЕНТОВ ПОСЛЕ ГЕМОРРОИДЭКТОМИИ С ИСПОЛЬЗОВАНИЕМ КЛАССИЧЕСКОГО МЕТОДА МИЛЛИГАНА-МОРГАНА И ГЕМОРРОИДЭКТОМИИ АППАРАТОМ «LIGASURE» Гавриков А.К., Новиков Ф.В., Гаврикова Д.И., Старкова О.А.

СУДЬБА ВОЕННОГО ХИРУРГА ПРОФЕССОРА В.А.ЕМЕЛЬЯНОВА КАК ПРИМЕР СЛУЖЕНИЯ ЛЮДЯМ Теремов Д.Д., Нагорная С.В.

ТОПОГРАФО-АНАТОМИЧЕСКИЕ ПРЕДПОСЫЛКИ К РАЗРАБОТКЕ СПОСОБОВ ГЕМОСТАЗА НА СЕЛЕЗЁНКЕ РагИмов Г.С., РагИмова Р.И.

ТРУДНЫЕ ВОПРОСЫ МОДЕРНИЗАЦИИ НЕПРЕРЫВНОГО МЕДИЦИНСКОГО ОБРАЗОВАНИЯ ХИРУРГИЧЕСКИХ СПЕЦИАЛЬНОСТЕЙ Григорьев Н.Н., БондареВ Г.А., Бобровская Е.А., Кононенко К.В.

ЭКСПЕРИМЕНТАЛЬНОЕ ОБОСНОВАНИЕ ВЫБОРА ШОВНОГО МАТЕРИАЛА ДЛЯ ОПЕРАЦИЙ НА ПЕЧЕНИ С УЧЕТОМ ЕГО ФИЗИКО-МЕХАНИЧЕСКИХ СВОЙСТВ ЛИПаТОВ В.А., ДенИСОВ А.А., ТрОфИМОВ И.В.

ЭКСПРЕССИЯ PGRMC1 И GALECTIN-1 ПАРЕНХИМАТОЗНЫМ КОМПОНЕНТОМ ЭНДОМЕТРИОИДНОЙ АДЕНОКАРЦИНОМОЙ ЭНДОМЕТРИЯ ПРИ ВОЗДЕЙСТВИИ ПРЕДОПЕРАЦИОННОЙ ГАММА-ЛУЧЕВОЙ ТЕРАПИЕЙ ДМитрий Александрович Зиновкин .73 ФОТОМАТЕРИАЛЫ КУзНецОв Д.А 


\section{ПРОГРАММА КОНФЕРЕНЦИИ}

Приветственное слово руководителей научно-исследовательских институтов и лабораторий КГМУ, структурных подразделений университета, гостей.

Роль эксперимента в хирургии и онкологии: от идеи до инноваций Вячеслав Александрович Липатов

Д.м.Н., профессор, зав. лабораторией экспериментальной хирургии и онкологии НИИ ЭМ КГМУ

Технологические возможности Минского технопарка, проекты, перспективы развития и сотрудничества

Владимир Александрович Давидович

директор ООО «Минский городской технопарк»

Практика продвижения инновационных разработок в области медтех

Павел Михайлович Бычковский

директор УНП РУП «Унитехпром БГУ»

Возможности и перспективные проекты студенческой научной лаборатории КГМУ

Ирина Леонидовна Привалова

д.м.н., профрессор, руководитель студенческой научной лаборатории

Пути управления регенерацией в хирургии

М. Давид Зияуддин Наимзада

младший научный сотрудник лаборатории экспериментальной хирургии и онкологии НИИ ЭМ КГМУ 
Гемостатические порошки нового поколения

Сергей Анатольевич Николаев

студент 4 курса педиатрического фракультета КГМУ

Исследование широкополосного электромагнитного излучения и его воздействия на биологические объекты с целью определения возможности использования в медицинских целях

Андрей Сергеевич Руцкой

к.т.н., директор, руководитель отдела НИОКР ООО «Парамерус»

Виктор Петрович Зыков

инженер-разработчик ООО «ПАРАМЕРУС»

Модификация губчатых полимерных гемостатических имплантов

Константин Александрович Сотников

врач ГКБ им. С.П. Боткина, г. Москва

Методология сравнительного анализа гемостатической эффрективности и безопасности губчатых полимерных имплантов

Дмитрий Андреевич Северинов

Ассистент кафедры детской хирургии и педиатрии ФПО КГМУ

Перспективы применения имплантов в хирургии почек

Вячеслав Романович Ветров

врач КГК БСМП, Курск

Испытания прочностных характеристик шовных материалов в аспекте хирургических вмешательств на паренхиматозных органах

Артем Александрович Денисов

студент 6 курса лечебного фракультета КГМУ 


\section{АУТОВЕНОЗНЫЕ РЕКОНСТРУКЦИИ АОРТО-ПОДВЗДОШНОГО СЕГМЕНТА У ПАЦИЕНТОВ С ВЫСОКИМ РИСКОМ ИНФЕКЦИОННЫХ ОСЛОЖНЕНИЙ}

Лызиков А.А.

Гомельский государственный медицинский университет

Стенозирующие поражения терминальных ветвей брюшной аорты являются распространенной причиной перемежающейся хромоты и подлежат хирургическому лечению. Более сложной ситуация становится при наличии гнойно-некротических изменений различной выраженности - от ишемического некроза пальцев стопы до гангрены. Одним из наиболее эффективных альтернатив искусственному эксплантату является бедренная вена, предложенная для репротезирования по поводу нагноения аорто-бедренного искусственного протеза P.Clagett в 1991 году.

Проанализировав наш опыт лечения поздних осложнений со стороны искусственных протезов сосудов, мы пришли к выводу, что большинству пациентов (более 90\%), первично были выполнены аорто-бедренные реконструкции эксплантатом по поводу критической ишемии с трофическими изменениями разной степени выраженности, при этом у большинства пациентов при первичной госпитализации не было клинических и лабораторных признаков системного присутствия инфекции. Предположив причиной развития поздних осложнений со стороны искусственного протеза его инфицирование во время имплантации и определив спектр возможных возбудителей, мы провели ряд экспериментов с моделированием субклинической и субкультуральной бактериемии. В результате нами было установлено отсутствие непосредственной зависимости развития инфекционных осложнений от дозы инфицирующего агента. Это позволило нам считать, что применение искусственного протеза при наличии трофических нарушений кожных покровов любой степени выраженности сопровождается высоким риском развития инфекционных осложнений. Поэтому мы полагаем оправданным применение бедренной вены для первичной реконструкции аорто-бедренного сегмента при наличии у пациента гнойно-некротических изменений и для повторных операций по поводу осложнений со стороны ранее имплантированного протеза даже при отсутствии признаков его нагноения.

Материал и методы.

За период 2010-2019 гг. в отделении хирургии сосудов Гомельского областного клинического кардиологического диспансера мы выполнили 22 реконструкции аортоподвздошного сегмента с использованием бедренной аутовены. Все пациенты были мужчинами в возрасте $58,8 \pm 4,5$ года. Степень хронической артериальной недостаточности определяли по классификации Покровского-Фонтейна. 
Были выделены следующие группы пациентов. В первую группу вошли пациенты, обратившиеся по поводу поздних осложнений ранее выполненных аорто-бедренных реконструкций эксплантатом. Вторую группу составили пациенты с критической ишемией нижних конечностей с гнойно-некротическими изменениями (ХАН 4), которым было отказано в выполнении аорто-бедренных реконструкций с применением искусственного протеза и рекомендована ампутация на уровне бедра. Также эти пациенты не подходили для стентирования пораженного сегмента из-за распространенности поражения. В этой группе выполнялась первичная реконструкция бедренной веной. Один пациент был оперирован по поводу нагноения искусственного протеза, что соответствует классическим показанием для операции Clagett.

Перед операцией всем пациентам выполняли дуплексное ультразвуковое исследование с определением лодыжечно-плечевого индекса (ЛПИ) и ангиографию или мультиспиральную компьютерную томографию с контрастированием.

В группе первично оперированных по поводу критической ишемии нижних конечностей с гнойно-некротическими поражениями пациентов были выполнены следующие оперативные вмешательства: одностороннее аорто-бедренное шунтирование бедренной веной, одностороннее подвздошно-бедренное шунтирование бедренной веной и аортобедренное бифуркационное шунтирование комбинированным протезом, состоящим из политетрафторэтиленового (ПТФЭ) кондуита и бедренной вены.

83,3\% пациентов, входящих в группу повторно оперированных по поводу поздних осложнений, находились в стадии субкомпенсации кровоснабжения нижних конечностей (ХАН 2а) и жалоб на выраженную перемежающуюся хромоту не предъявляли. Им были выполнены следующие оперативные вмешательства: в 1 случае мы выполнили удаление инфицированного протеза, ликвидацию кишечно-парапротезного свища с дренированием абсцесса и аорто-подвздошное репротезирование бедренной веной; в 6 случаях мы резецировали инфицированную браншу протеза с репротезированием бедренной веной.

Результаты и обсуждение.

Во всех случаях нам удалось добиться адекватной реваскуляризации.

В группе вторично оперированных пациентов все раны зажили первичным натяжением.

В группе первично оперированных пациентов к 4-5 суткам во всех случаях мы отмечали развитие выраженной лимфореи из послеоперационной раны на бедре, которая во всех случаях длилась до 10 суток. У всех пациентов участок разреза на уровне паха на этой ноге заживал вторичным натяжением. Все остальные операционные раны зажили первично. Во всех случаях для реабилитации потребовалось значительное время (около 30 суток) с лечением в отделении хирургии сосудов с последующим переводом в отделение гнойной хирургии. Внимания хирургов преимущественно требовали трофические язвы и лимфорея из разреза на ноге со стороны забора вены. Все пациенты отмечали исчезновение болей в покое, увеличение дистанции ходьбы сразу после операции и у всех отмечалась 
существенная активизация процесса заживления трофических язв. В одном случае через 3 месяца после операции у пациента развился сепсис с последующим тромбозом артерий голени и гангреной конечности, потребовавшей ампутации, несмотря на функционирование аутовенозного шунта. Таким образом, минимальная выживаемость шунта составила 3 месяца.

Течение послеоперационного периода со стороны нижней конечности, из которой забирали глубокую вену для реконструкции, было более тяжелым, чем в группе вторично оперированных пациентов, несмотря на потребовавшуюся меньшую длину венозного трансплантата и, соответственно, меньшую длину разреза на бедре. Причем наблюдаемые клинические проявления были вызваны в большей степени нарушением лимфатического оттока, чем венозной недостаточностью. По всей вероятности, причиной этих нарушений явилось наличие некротического очага как источника инфекции, создающего функциональную перегрузку лимфатического дренажа конечности, и выраженная ишемия нижней конечности (ХАН 4) до операции.

Однако, несмотря на все вышеизложенное, у всех пациентов нам удалось устранить проявления критической ишемии и избавиться от болей в покое, выиграв время для заживления трофических поражений. Несмотря на осложненное течение послеоперационного периода, во всех случаях мы не наблюдали нарушения функционирования венозных кондуитов. Также в 100\% наблюдений нарушения венозного оттока не требовали дополнительных лечебных мероприятий и не являлись показаниями к фасциотомии.

Заключение

В результате проведенных исследований нами было установлено следующее:

Изъятие бедренной вены для реконструкции не приводит к выраженным нарушениям венозного оттока и развитию хронической венозной недостаточности.

Несмотря на необходимость в длительном лечении после операции, аутовенозная реконструкция аорто-подвздошного сегмента у пациентов с гнойно-некротическими нарушениями является менее рискованной с точки зрения поздних инфекционных осложнений, чем имплантация искусственного протеза и более выигрышной с точки зрения качества жизни, чем первичная высокая ампутация.

\section{Список литературы.}

1. Северинов Д.А., Кузьмина Н.М., Кузьмин А.В., Самарский И.С., Липатов В.А. Исследование физико-механических свойств брюшного отдела аорты в зависимости от возрастных изменений // Innova. - 2018. - №11 (2). - С. 28-30.

2. Суковатых Б.С., Великих М.В. Влияние стентирования коронарных артерий на качество жизни больных с ишемической болезнью сердца // Innova. - 2018. - №11 (2). - C. 34-36. 
3. Троицкий АВ, Лысенко ЕР, Хабазов РИ, Азарян АС, Грязнов ОГ, Соловьева ЕД и др. Аутовенозные реконструкции при инфекции аортобедренных синтетических протезов. Кардиол. и серд.-сосуд. хирургия. - 2008. - 8. -46-51.

4. Post ICJH, Vos CG Systematic Review and Meta-Analysis on the Management of Open Abdominal Aortic Graft Infections. Eur J Vasc Endovasc Surg. 2019 Aug;58(2):258-281.

5. Antonello RM, D'Oria M, Cavallaro M, Dore F, Cova MA, Ricciardi MC, Comar M, Campisciano G, Lepidi S, De Martino RR, Chiarandini S, Luzzati R, Di Bella S. Management of abdominal aortic prosthetic graft and endograft infections. A multidisciplinary update.J Infect Chemother. 2019 Sep;25(9):669-680.

6. Liu RH, Fraser CD 3rd, Zhou X, Beaulieu RJ, Reifsnyder T. Complete versus partial excision of infected arteriovenous grafts: Does remnant graft material impact outcomes?J Vasc Surg. 2019

7. Zamani N, Sharath SE, Barshes NR, Braun JD, Kougias P. Long-term outcomes of lower extremity graft preservation using antibiotic beads in patients with early deep wound infections after major arterial reconstructions. J Vasc Surg. 2019 Sep 10.

8. [Autogenous superficial femoral vein for replacement of an infected aorto-ilio-femoral prosthetic graft]. / Staffa R, [et al]//Rozhl Chir. - 2010. - №89(1). - pp.39-44.

\section{ВИРУСНЫЙ ГЕПАТИТ А И ПРОБЛЕМЫ ВАКЦИНОПРОФИЛАКТИКИ Юсупов Ш.Ш., Матназарова Г.С., Рахманова Ж.А., Жумамуродов С.Т.} Ташкентская Медицинская Академия

Вирусный гепатит A - острое, циклически протекающее заболевание, вызываемое РНКсодержащим вирусом; характеризуется кратковременными симптомами интоксикации, быстро проходящими нарушениями печёночных функций с доброкачественным течением. Вирусный гепатит А - распространённое инфекционное заболевание в детском возрасте. Заболеваемость бывает спорадической или в виде эпидемических вспышек Вирусный гепатит А - типичная антропонозная инфекция, Источником инфекции может быть только человек с явными или стёртыми формами болезни, а также вирусоноситель - здоровый или реконвалесцент [1,3].

Вирусный гепатит А относится к числу наиболее широко распространенных в мире кишечных инфекционных заболеваний. ВОЗ сообщает о приблизительно 1,4 млн. случаев гепатита A, регистрируемых ежегодно, наибольшая восприимчивость к ВГА характерна для детей от 2 до 7 лет, но может встречаться до 14 лет [1].

ВГА инфекционное заболевание с фекально-оральным механизмом передачи возбудителя, заболевание характеризуется циклическим течением, кратковременной 
интоксикацией, преимущественным поражением печени и благоприятными исходами в подавляющем большинстве случаев [1,3].

Михайлов М.И. с соавтор. указывает, что бороться с ВГА можно двумя путями. Первое это кардинально изменить в лучшую сторону санитарно-гигиеническую обеспеченность жизни россиян. Этот путь ясен, но его реализация в самое ближайшее время маловероятна. Второе - провести широкомасштабную вакцинацию, прежде всего лиц, составляющих группы повышенного риска инфицирования [4].

В России, например, зарегистрировано несколько вакцин, полученных по сходной технологии. G. laxo Smith Kline Хаврикс 1440 и 720. В качестве основы здесь применяется инактивированный штамм вируса, обозначенный HМ 175, выращенный на культуре клеток. Цифры 1440 и 720 обозначают количество частиц инактивированного ВГА в одной дозе вакцинного препарата. Наряду с вакциной Хаврикс зарегистрированы Вакта (фирма MSD CША); Аваксим (фирма Aventis, Франция) и “Геп-А-ин-Вак", разработанный в 19861993 годах в Институте полиомиелита и вирусных энцефалитов им М.П. Чумакова РАМН и промышленно выпускаемый НП “Вектор”.

Всеобщую вакцинацию предлагает проводить поэтапно, из-за финансовых проблем затрудняющих 100\%-ное обеспечение препаратом.

Первый этап - прививать организованные детские коллективы, где на протяжении многих лет регистрируется ВГА [1].

Второй этап - охват прививками всех организованных детей и неорганизованных дошкольников, призывников в армию, работников предприятий общественного питания.

Третий этап - (идеальный) - все дети до 15 лет него возраста и выборочно серонегативные взрослые.

На сегодняшний день зарегистрированы и разрешены к применению следующие вакцины:

- Вакцина против гепатита А очищенная концентрированная адсорбированная инактивированная жидкая ГЕП-А-ин-ВАК*, Россия;

- Вакцина против гепатита А с полиоксидонием ГЕП-А-ин-ВАК-пол*. Россия; -с- хаврикс* 1440 фирмы «ГлаксоСмитКляйн*. Англия; ф хаврикс* 720 фирмы «ГлаксоСмитКляйн», Англия;

- Аваксим* фирмы «Авентис Пастер», Франция:

- Вакта* 25 ЕД (50 ЕД) фирмы «Мерк Шарп и Доум*>, США;

- Твинрикс* - вакцина против гепатитов А и В фирмы «ГлаксоСмитКпяйн», Англия.

В Узбекистане, приказом № 542 от 27.08.2018г. «О совершенствовании диагностики, лечения и профилактики вирусных гепатитов В Республике Узбекистан» очень ясно 
описаны все профилактические мероприятия для предупреждения ВГА, также отражены вопросы вакцинации. [9]

Положительный эффект получен при использовании вакцины “Хаврикс"- при ликвидации крупных вспышек в Словакии на Аляске; в Монреале, в провинции Бари, Юго-Восточная Италия [6]. Охват 70-80 \% лиц, обеспечивает высокую эффективность данного мероприятия. Изучая эффективность вакцины Харвикс в национальном центре контроля инфекционных заболеваний в Атланте установлено было, что в опытной группе животных вакцинированных двухкратно против ВГА, даже после искусственного заражения не возникало заболеваний $[6,7]$.

Многочисленные исследования по оценке защитного уровня анти - ВГА показали что, через один месяц антитела в защитном титре вырабатываются у 94-98 \% привитых лиц. Повторное введение вакцины обеспечивает 99-100\%ное наличие анти - ВГА [7]. Данные о продолжительности поствакционального иммунитета свидетельствует о том, что он может сохраняться, по крайней мере, 10-20 лет.

При оценке иммуногеном активности вакцины против ГА типа "Хаврикс 720" анти - ВГА выявлены против в 97,3 и 93,5 \% случаев, и это только после однократной иммунизации $[4,8]$.

Проведенная в 2002 году вакцинация против ВГА более 35 тысяч населения из групп высокого риска в районах стихийных бедствий, в первую очередь на юге России позволила удержать под контролем санитарно-эпидемиологическую обстановку в этом регионе страны и не допустить развития вспышек ВГА. Далее автор отмечает, что не в полной мере используются вакцины российских технологий “НПК Комбиотех и НПО “Биомед" г. Пермь комбинированной вакцины против гепатитов А и В [3, 5].

В Узбекистане, рекомендовано детей до 6 лет вакцинировать от вирусного гепатита А, для профилактики распространения данного заболевания.

Таким образом, анализ литературных данных дает четкую информацию, о необходимости, дальнейшего внедрения вакцинации от вирусного гепатита А среди детей дошкольного возраста, как один из наиболее эффективных методов профилактики данного заболевания.

\section{Список литературы.}

1. Балаян М.С. Замятина Н.А. Вирусный гепатит: новые данные //Клинич. мед. -2001 -№6 -C. 14-17.

2. Брико Н.И. Клинико - эпидемиологическая характеристика и основные направления профилактики гепатита А // Леч.врач. - 2011-№5-6. С.54-57 
3. Каира А.Н., Ющенко Г.В. Опыт вакцино-профилактики гепатита А в Московской области. //Эпидемиология и инфекционные болезни - 2002 №4 С.61-62

4. Михайлов М.И., Шахгильдян И.В. Гепатит А - проблемы диагностики, эпидемиология и вакцинопрофилактика вирусного гепатита А в Ростовской области. //Лечещий врач - 2014 №8 C.50-53

5. Онищенко Г.Г. Официальная статистика заболеваемости гепатитом А в России. //Бюллетень Вакцинация №3(3) май-июнь 1999г

6. B. H. Robertson, B. Khanna, Harold S. Margolis "Genetic Variation of Wild-type hepatitis A Isolates ", //“ Viral hepatitis and Liver disease "2017y p-54-58

7. Takahashi Y, Shimizu M and the study Group of Fulminant Hepatitis. Aetiology and prognosis of Fulminant viral hepatitis in Japan:// A multicentre study. Journal Gastroenterol Hepatol 2011. №6 p 159-164

8. Jacobsen $\mathrm{KH}$, Wiersma ST. Hepatitis A virus seroprevalence by age and world region, 1990 and 2005. Vaccine 28 (2010) 6653-6657.

9. Приказ № 542 от 27.08.2018г. «О совершенствовании диагностики, лечения и профилактики вирусных гепатитов В Республике Узбекистан»

ВЛИЯНИЕ ВОДОРОДНОГО ПОКАЗАТЕЛЯ НА РЕЗУЛЬТАТЫ ЛЕЧЕНИЯ ИНФИЦИРОВАННЫХ РАН НА ФОНЕ ХВН С ПРИМЕНЕНИЕМ БАКТЕРИАЛЬНОЙ ЦЕЛЛЮЛОЗЫ В ЭКСПЕРИМЕНТЕ И КЛИНИКЕ Винник Ю.С. ${ }^{1}$, Шишацкая Е.И.3, Тюхтева Н.М. ${ }^{1}$, Захарченко А.А.1,2, Соловьева Н.С.", Шидловский И.П. ${ }^{3}$

Красноярский государственный медицинский университет им. проф. В.Ф. ВойноЯсенецкого ${ }^{1}$

\section{Дорожная клиническая больница²}

\section{Сибирский федеральный университет ${ }^{3}$}

Цель работы: изучить изменения водородного показателя инфицированных ран венозной этиологии на фоне применения покрытий биологического происхождения в эксперименте и клинике.

Материалы и методы: для оценки применения раневого покрытия биологического происхождения на процессы ранозаживления проведены экспериментальные исследования на 10 крысах 3-х месячного возраста обоего пола с массой тела от 250 до 
300 г. У лабораторных животных не имелось признаков сопутствующей патологии. Условия содержания животных в виварии были стандартными.

До проведения экспериментального исследования крыс взвешивали, тщательно осматривали на наличие видимой патологии и признаков болезней. Крысы, включенные в эксперимент, содержались в отдельном боксе в течение одной недели для адаптации к новым условиям.

Моделирование ран выполняли следующим образом: под общим обезболиванием (внутрибрюшинное введение 0,5-0,7 мл. 1\% раствора тиопентала натрия, экспозиция 1520 мин), затем животное фиксировали на спине, выбривали участок кожи в проекции бедренной вены размерами $20 \mathrm{~cm} 2$, перманентным маркером намечали контур будущей раны $[1,6]$. Поверхность кожи дважды обрабатывали антисептиком Хлоргексидин, наносили рану округлой формы примерно 2,5 cм. в диаметре, путем рассечения мягких тканей до фасции, далее тупым путем расслаивали ткани до бедренной вены. Далее на 2 минуты накладывали зажим на вену, создавая условия характерные для венозной недостаточности.

В качестве микробного агента в процессе моделирования гнойной раны использовали 3-х млрд. суточную культуру Staphylococcus aureus, штамм 209P, обладающий лецитиназной, гемолитической активностью и дающий положительную дерматонекротическую пробу. Микробную взвесь вводили инъекционно в мягкие ткани дна раны. После получения модели инфицированной раны проводилось наблюдение за состоянием раневых дефектов. Оценивали наличие признаков воспаления, характер и количество раневого отделяемого, а также размеры раневого дефекта. Сроки наблюдения за животными составили 6, 14, 21 и 28 сутки. Животных выводили из эксперимента на 28-е сутки наблюдения. Консервативная терапия включала: санацию растворами антисептиков, ежедневные перевязки.

Клинически раневые покрытия применены у 20 пациентов с трофическими язвами на фоне ПТФБ (посттробофлебитического синдрома) без признаков системного воспаления, находившихся на стационарном лечении в хирургическом отделении №2 ДКБ ОАО «РЖД на ст. Красноярск». Критерии включения в исследование: больные обоего пола, в возрасте от 33 до 81 года. Критерии исключения: сахарный диабет I и II типа с развитием синдрома диабетической стопы хроническая ишемия на фоне атеросклероза сосудов нижних конечностей, наличие беременности, онкологического заболевания, хронического соматического заболевания в стадии декомпенсации. Все пациенты получали базисную консервативную терапию, включающую санацию растворами антисептиков, ежедневные перевязки. Базисная консервативная терапия включала: санацию растворами антисептиков, ежедневные перевязки. Среди пациентов 55,45\% составили женщины и 44,55\% мужчины. Для лечения больные поступали в плановом порядке. Для улучшения микроциркуляции, тонуса венозной стенки, назначался препарат Детралекс в стандартных дозировках. С целью повышения трофики тканей применялись производные Пентоксифиллина в суточной дозе 1200 мг. При наличии признаков 
атопического дерматита или экземы в комплексное лечение включали блокаторы гистаминовых рецепторов (супрастин). Сроки наблюдения составили 6, 14, 21 и 28 сутки.

В исследуемых группах применяли оригинальные раневые покрытия на основе целлюлозы бактериального происхождения. В качестве продуцента целлюлозы использован штамм Komagataeibacter xylinus IBP/SFU-MG PV0, выделенный из природной ассоциации Medusomyces gisevii J. Lindau (чайный гриб) селекционным путем на стандартной среде Hestrin-Schramm (HS). Штамм Komagataeibacter xylinus IBP/SFU-MG PV0 депонирован во Всероссийской коллекции промышленных микроорганизмов (ВКПМ) (коллекционный номер ВКПМ В-12068) и запатентован [8].

Водородный показатель $\mathrm{pH}$ характеризует кислотно-основное равновесие, определяющееся концентрацией ионов водорода $\mathrm{H}+$. Норма показателя $\mathrm{pH}$ кожного покрова в среднем составляет 5,5. Свеженанесенная асептическая рана имеет щелочную реакцию среды, острая гнойная - кислую ( $\mathrm{pH}<7)$, при хронической ране отмечается сдвиг pH в сторону алкалоза (pH > 7) $[2,4,7]$.

Для определения показателя рН раневой поверхности использовали портативный контактный рН-метр Ні 99181 (Германия).

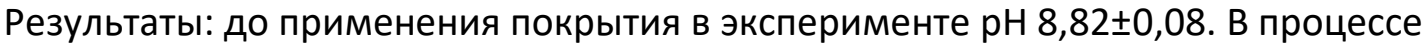
применения раневого покрытия на основе бактериальной целлюлозы показатель рН

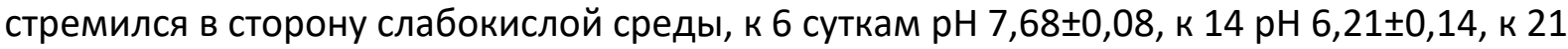

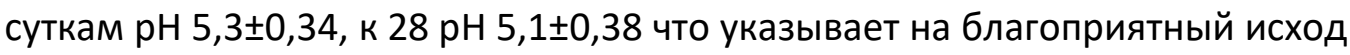
воспалительного процесса, при норме рН кожного покрова 5.5.

В клинике у пациентов с ПТФБ рН до лечения составляет в среднем 8,67 $\pm 0,09$. Благодаря методу лечения с применением раневого покрытия на основе бактериальной целлюлозы,

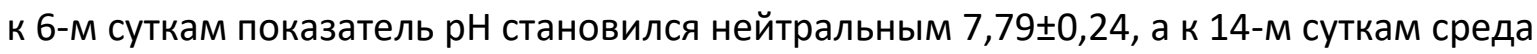

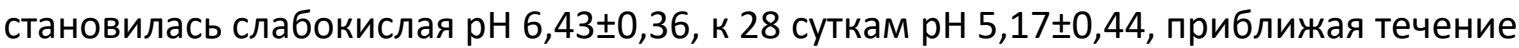
раневого процесса к наиболее оптимальным значениям.

Таким образом, применение раневых покрытий биологического происхождения создает оптимальный микроклимат в ране, приближая рН к естественным слабокислым показателям, нормализуя течение раневого процесса.

\section{Список литературы.}

1. Абаев, Ю. К. Заживление острых и хронических ран. Сообщение ІІ / Ю. К. Абаев // Военная медицина. - 2010. - № 2. - С. 106-110.

2. Аралова, М. В. Лечение трофических язв нижних конечностей гидроактивными раневыми покрытиями / М. В. Аралова // Вестн. новых мед. технологий. - 2013. - Т. 20, № 2. - С. 25-28. 
3. Бауэрзакс, Ж. Патофизиология хронической венозной недостаточности / Ж. Бауэрзакс, Ж. И. Флеминг, Р. Буссе // Флеболимфология. - 1998. - № 7. - С. 1-7.

4. Беликов, Д. В. Возможности оптимизации лечения больных трофическими язвами венозной этиологии / Д. В. Беликов, Е. А. Улаева, Е. В. Королёва // Междунар. журн. эксперим. образования. - 2015. - № 6. - С. 54.

5. Винник, Ю. С. Современные методы лечения гнойных ран / Ю. С. Винник, Н. М. Маркелова, В. С. Тюрюмин // Сиб. мед. обозрение. - 2013. - № 1. - С. 18-24.

6. Влияние кислотности на динамику репаративных процессов в мягких тканях / А. А. Андреев, А. А. Глухов, А. П. Остроушко [и др.] // Вестн. эксперим. и клин. хирургии. - 2017. - T. 10, № 1. - С. 64-71.

7. Глухов, А. А. Патофизиология длительно незаживающих ран и современные методы стимуляции раневого процесса / А. А. Глухов, М. В. Аралова // Новости хирургии. - 2015. Т. 23, № 6. - С. 673-679.

8. Production and properties of bacterial cellulose by the strain Komagataeibacter xylinus B12068/ T. G.Volova, S. V. Prudnicova, A. G. Sukovatyi, E. I. Shishatskaya / Applied microbiology and biotechnology//- 2018. - T.102. - №17. - P.7417- 7428.

\section{ГИСТЕРОСКОПИЧЕСКАЯ И МОРФОЛОГИЧЕСКАЯ ОЦЕНКА ВНУТРИМАТОЧНОЙ ПАТОЛОГИИ В ВОЗРАСТНОМ АСПЕКТЕ Колесникова И. О., Сулима А. Н., Давыдова А. А.}

Медицинская академия им. С. И. Георгиевского (структурное подразделение) «Крымского федерального университета им. В. И. Вернадского»

Цель. Провести гистероскопическую и морфологическую оценку внутриматочной патологии в возрастном аспекте.

Методы исследований. Проведен ретроспективный анализ 100 видеопротоколов гистероскопий и данных морфологических исследований, полученного во время операции материала, в ООО «Медицинская клиника «Ваш Доктор» (г. Симферополь) за 2018 год. Исследование завершалось диагностическим выскабливанием полости матки (ПМ) и цервикального канала (ЦК), с последующей контрольной гистероскопией.

Результаты. Гистероскопия проведена 100 пациенткам в возрасте от 20 до 55 лет. В ходе ретроспективного анализа гистероскопических картин $[1,2]$ и патоморфологических 
исследований [3] все пациентки были разделены на возрастные группы: I группа - 25-35 лет (35 женщин), II группа - 36-45 лет (35 женщин), III группа - 46-55 лет (30 женщин).

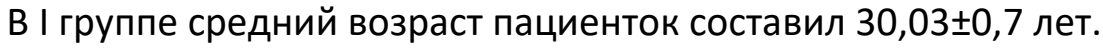

1. Гиперплазия эндометрия диагностирована у $45,7 \%$ пациенток, в основном с жалобами на аномальные маточные кровотечения (АМК), нарушения овариально-менструального цикла (ОМЦ) и бесплодие. При гистероскопической картине - эндометрий был утолщен, ярко-розовой окраски, визуализировались прозрачные точки - увеличенное количество протоков желёз. При оценке распространенности патологического процесса - диффузная гиперплазия диагностирована у $61,3 \%$ пациенток, очаговая - в 38,7\%. Согласно морфологическому исследованию, у большинства пациенток отмечалась гиперплазия без атипии $(87,67 \%)$.

2. Полипы тела матки диагностированы в 31,4\% случаев, основными клиническими проявлениями которых являлись аномальные маточные кровотечения (AMK) (74,2\%), у остальных пациенток $(25,8 \%)$ - бессимптомное течение. Гистероскопически определялись образования бледно-розового цвета на ножке, округлой формы с гладкой поверхностью. Размеры полипов по данным гистероскопии варьировали: мелкие - размером 0,3 - 0,5 см встречались у 44,0\% женщин, средние - до 1,0 см диагностированы в 66,0\% случаев. По данным гистологического исследования преобладали железистые полипы эндометрия $(81,8 \%)$.

3. Гистероскопическая картина хронического эндометрита (слизистая бледно-розовой окраски, неравномерной окраски и толщины, с чередованием неизмененных участков эндометрия с участками истонченного, выраженным сосудистым рисунком) выявлена в $22,8 \%$ случаев. Пациентки предъявляли жалобы на невынашивание беременности и/или бесплодие. У 8,6\% пациенток гистероскопически диагностированы внутриматочные синехии. По распространённости и степени облитерации полости матки: I степень - В 65,8\% случаев (спайки тонкие, устья маточных труб проходимы); II степень - в 34,2\% (бессосудистые тяжи, устья маточных труб на 2/4-3/4 непроходимы). Проведенное морфологическое исследование в 83,3\% случаев показало очаговую лимфоплазмоцитарную инфильтрацию эндометриальной стромы, фиброз и атрофию эндометрия различной степени выраженнности, в некоторых случаях нейтрофильные гранулоциты.

4. В 11,4\% случаев визуализировалась нормальная гистероскопическая картина эндометрия с соответствием его фазе ОМЦ, подтвержденная морфологическим исследованием.

Вo II группе возраст пациенток в среднем составил 41,4士0,6 года.

1. Гистероскопическая картина хронического эндометрита отмечалась в $37,1 \%$ случаев. У всех пациенток с данной патологией имелось в анамнезе указание на предыдущие внутриматочные вмешательства по поводу бесплодия или неполный аборт. Визуализировался светло-розовый эндометрий с неравномерным утолщением и 
обильной васкуляризацией. Морфологически преобладала лимфоидно-клеточная инфильтрация с плазматическими и гистиоцитарными элементами, фибробластической перестройкой стромы и сосудов. Среди них в 60,8\% отмечался склероз стенки сосудов; в 39,2\% - полнокровные расширенные сосуды с периваскулярным отеком и выходом форменных элементов крови за пределы микроциркуляторного русла.

2. В 34,2\% случаев диагностирована гиперплазия эндометрия, с преобладанием ее диффузной формы (66,7\%). Пациентки предъявляли жалобы на АМК. При гистероскопии визуализировались бахромчатые обрывки эндометрия в области дна матки и устьев маточных труб бледно-розовой окраски. Гистологическое исследование выявило наличие желез различной формы и размеров, распределенных неравномерно в строме с ростом железисто-стромального соотношения и увеличением числа эндометриальных желез 3:1.

3. При проведении исследования полипы тела матки диагностированы у 31,4\% пациенток, основными клиническими проявлениями которых были АМК. Гистероскопически визуализировались образования серо-розового цвета, продолговатой и округлой формы. Преобладали средние размеры полипов эндометрия - до 1,0 см $(83,8 \%)$, и крупные - до 2,0 - 3,0 cм (16,2\%). При гистологическом исследовании преобладали железистые $(71,9 \%)$ полипы эндометрия.

4. Эндометрий с признаками гипопластического типа выявлен у $11,4 \%$ женщин (тусклая белесоватая слизистая с преобладанием истонченного эндометрия). Пациентки предъявляли жалобы на бесплодие и привычное невынашивание беременности. На микропрепаратах визуализировались единичные слабо развитые железы, местами с кистозным расширением в плотной строме со щелевидными сосудами.

В III группе средний показатель возраста составил 50,9ะ2,3 лет.

1. В 43,3\% случаев у данной категории женщин диагностированы полипы тела матки. В структуре жалоб преобладали АМК. Гистероскопически визуализировались овальные образования бледно-розового цвета с гладкой поверхностью и незначительной васкуляризацией на ножке. Крупные полипы тела матки отмечались в 20,7\% (1,5 - 2,0 см), средние - в 78,5\% случаев (1,0см). По морфологии в структуре превалировали железистые полипы эндометрия (62,8\%).

2. В постменопаузальном периоде атрофия эндометрия была выявлена в 30,0\% случаев. Визуализировалась тонкая и бледная слизистая оболочка полости матки, с облитерированными устьями маточных труб. Микроскопически преобладали незрелые атрофичные железы с выраженной дистрофией эпителия.

3. Диффузная гиперплазия эндометрия при гистероскопическом исследовании выявлена у $20,0 \%$ обследованных в данной группе. Визуализировалось утолщение эндометрия, а в ряде случаев его полиповидные разрастания светлого цвета с пузырьками на поверхности. При морфологическом исследовании образцов эндометрия простая железистая гиперплазия без атипии встречалась в 85,0\% случаев, а в 15,0\% диагностирована атипическая гиперплазия. 
4. У 6,7\% пациенток III группы выявлена и морфологически подтверждена аденокарцинома эндометрия с жалобами на патологические выделения из половых путей в постменопаузе. При гистероскопическом исследовании ткань эндометрия крошилась и кровоточила вследствие изменения вводимой жидкости в полость матки. Патологический процесс имел вид папилломатозных разрастаний серого цвета, обильно васкуляризированный, с фрагментами некроза ткани. Морфологически визуализировались различного размера железы эндометрия с нарушенным порядком расположения относительно друг друга и полным отсутствием связующей стромы между ними. Отмечалась выраженная атипия опухолевых клеток с полиморфизмом ядер и множественными митозами.

Несоответствие количества случаев общему числу женщин в каждой группе связано с наличием одновременно нескольких патологий у одной пациентки.

Выводы. Гистероскопия с морфологическим исследованием эндометрия является «золотым» стандартом в диагностике внутриматочной патологии в возрастном аспекте. На основании проведенного исследования можно сделать вывод о различной структуре внутриматочной патологии у женщин в разные периоды жизни: преобладании диффузной гиперплазии эндометрия в раннем репродуктивном возрасте, хронического эндометрита в позднем репродуктивном возрасте и полипов тела матки в периоде менопаузального перехода и постменопаузы. Полученные данные помогут врачу-клиницисту своевременно поставить правильный диагноз и выработать оптимальную и индивидуальную тактику ведения пациентки.

\section{Список литературы.}

1. Савельева Г. М., Гистероскопия : атлас и руководство [Электронный ресурс] / Г. М. Савельева, В. Г. Бреусенко, Л. М. Каппушева -

М. : ГЭОТАР-Медиа, 2018. - 248 с. - Режим доступа:

http://www.rosmedlib.ru/book/ISBN9785970443811.html

2. Ключаров, И. В. Гистероскопия в комплексной диагностике патологии полости матки и эндометрия / И. В. Ключаров, Л. И. Трубникова,

А. А. Хасанов // Ульяновский медико-биологический журнал. - 2013. - № 1. - С. 155-158.

3. Кондриков, Н. И. Патология матки. Руководство для врачей /

Н. И. Кондриков, И. В. Баринова - 2-е изд. - М.: Практическая медицина, 2019. - 352с.:ил. 


\title{
ЗНАЧЕНИЕ СОВРЕМЕННОГО КОМПЛЕКСНОГО УЛЬТРАЗВУКОВОГО ИССЛЕДОВАНИЯ В ДИАГНОСТИКЕ ОЧАГОВЫХ ОБРАЗОВАНИЙ ЩИТОВИДНОЙ ЖЕЛЕЗЫ
}

\author{
Хушназаров X. X.
}

\section{Ташкентский институт усовершенствования врачей}

Актуальность. Согласно последним статическим данным, распространенность узловых образований щитовидной железы (ЩЖ) в течение последних 30 лет возросла с 4-9\% до 5$22 \%$, и за минувшее десятилетие рак щЖ, являющийся причиной летальности $1 \%$ онкобольных участился в 2 раза [4]. В связи с чем, в настоящее время важнейшими остаются проблемы ранней и дифференциальной диагностики узловых образований щЖ. Современная комплексная ультразвуковая диагностика, включающая эхографию и допплерографию, обогатилась принципиально новой технологией - эластографией, представляющей собой способ качественного и количественного анализа механических особенностей тканей посредством модуля упругости Юнга, определяющего способность мягких тканей оказывать сопративление растяжению/сжатию при упругой деформации $[2,5,6]$. Компрессионная эластография - общедоступный метод, предоставляющий качественную оценку дислокации упругости в тканях. Единственным условным количественным параметром компрессионной эластографии является коэффициент деформации SR (strain ratio), отражающий уровень компрессируемой ткани в интересуемой зоне по отношению к соотносимой ткани. Данная оценка жесткости тканей является индексом Юнга, который учитывает субъективные данные. Информация, полученная при использовании компрессионной эластографии, может быть продемонстрирована в виде графика или посредством цветового картирования [3,5]. Эластография «сдвиговой волны» - это метод, предоставялющий возможность дать количественную оценку упругости тканей и исключает вероятность субъективной трактовки данных $[2,3,5]$. Основой действия данной методики является генерация в тканях сдвиговой волны, вызванной ультразвуковым импульсом и последующим анализом скорости ее движения. При этом сам ультразвуковой датчик выполняет визуализацию прохождения сдвиговой волны. В соответствии с видом эластографии «сдвиговой волны», числовые значения показателя упругости выражаются в м/с или кПа. На основании этого, метод получил название «количественная ультразвуковая эластография или эластометрия».

Цель исследования. Улучшение дифференциальной и уточняющей диагностики очаговых образований щитовидной железы путем применения современного комплексного ультразвукового исследования.

Материалы и методы. Под наблюдением находились 60 пациентов, направленных на УзИ для уточнения характера узловых образований в щитовидной железе. Возраст пациентов варьировал от 22 до 68 лет. Среди обследованных пациентов мужчины и женщины 
составили 18 (33\%) и 42 (67\%) соответственно. УЗИ выполняли на современных ультразвуковых аппаратах «MINDRAY ДС-70»(Китай), и HI VISION Preirus Hitachi Medical Corporation, Япония), Logiq S8 XD clear GE Healthcare (США) с использованием линейных мультичастотных датчиков (диапазон частот 7,5-13 МГц) обеспечивающих визуализацию в реальном режиме серой шкалы, получение характеристик допплеровских исследований, эластографии. УЗИ выполняли по стандартной методике с проведением серошкального исследования, цветового и энергетического допплеровского картирования (ЦДК, ЭДК, спектральный допплер). В исследованиях также использовался режим эластографии (компрессионной и сдвиговой волны) с помощью которого оценивалась жесткость очаговых образований щитовидной железы.

Результаты исследования и их обсуждение. У 32 (52 \%) обследованных были выявлены единичные узлы щитовидной железы, у 28 (48 \%) выявлены множественные узловые образования. Поражение щитовидной железы преимущественно наблюдалось у 16 $(85,2 \%)$ женщин репродуктивного возраста. Наибольшую группу, из обследованных (n=39) 65\%, составили различные варианты диффузно-узлового зоба. Из 60 пациентов изменение размера, в сторону увеличения железы были у $41(68,3 \%)$, неровность контуров наблюдалось у $21(35,8 \%)$ пациентов, неравномерная эхогенность - у $27(47,5 \%)$, ободок «хало» - у 41(67,5\%), увеличение объема щитовидной железы у 44(78,3\%), кальцинаты у 21(34,2\%), гиперваскуляризация у 53(86\%) пациентов. Показатели эластичности ткани щитовидной железы были выше 163 кПа (норма 6,7-19,8 кПа.) у 52(86,6\%) больных. При проведении эластографии нормативный диапазон составил 16,7 19,8 кПа. При доброкачественных образованиях среднее арифметическая жесткость составила 47,5 \pm 10 кПа, что достоверно выше нормы: $(p<0,05)$. Гипоэхогенные очаговые образования размерами 6 - 15 мм характеризовались равномерным окрашиванием в синий цвет при эластографии. При выявлении очаговых образований смешанной эхогенности размерами превышающие 15 мм, а также изоэхогенных образований с гипоэхогенным ободком по периферии цитологические и гистологические заключения были фолликулярные аденомы без пролиферации. Образования имели мозаичную структуру окрашивания с преобладанием участков синего цвета и нескольких более жестких участков зеленого цвета.

Выводы. Таким образом, при современном комплексном ультразвуковом исследований очаговых образований щитовидной железы наиболее информативным ультразвуковым критерием явилось увеличение объема щитовидной железы, неровность контуров, наличие кальцинатов в структуре узлового образования, гиперваскуляризация и снижение эластичности пораженной ткани. Комплексное ультразвуковое исследование является доступным, высокоинформативным методом ранней и уточняющей диагностики рака ЩЖ и поражения лимфатических узлов шеи при наличии регионарного метастазирования. Чувствительность эхографии с использованием комплекса методики технологий в диагностике рака ЩЖ составила 89,6\%, специфичность - 81,5\%, диагностическая точность - 84,9\%. 


\section{Список литературы:}

1. Аденома - узловая форма заболевания щитовидной железы./Островский К.А., Шмейс

С.Н., Островский А.Г., и др.//Тенденции развития науки и образования. 2018. Т. 37. № -5. C. $39-44$.

2. Котова Е.В., Шитухина Е.В. Возможности ультразвукового исследования в дифференциальной диагностике очаговых образований щитовидной железы.//Бюллетень медицинских интернет-конференций.2018. Т. 8. № 3. С. 113.

3. Митьков В.В., Митькова М.Д. Ультразвуковая эластография сдвиговой волной.//Ультразвуковая и функциональна диагностика. 2015 № 2. С. 94-108.

4. Матвеев Г.А., Копина М.Н. Ультразвуковое исследование щитовидной железы как скрининговый метод диагностики ее изменений.//ченые записки Новгородского государственного университета. 2015№ 2 (2).С. 16.

5. Сенча А.Н., Могутов М.С., Беляев Д.В., Шмелев Д.М. Соноэластография в диагностике рака щитовидной железы // Ультразвуковая и функциональная диагностика. - 2009. - № 4. - C. 99.

6. Analysis of postoperative complications following total thyroidectomy / Atiq100. M.T. et al.. // Mymensingh Med. J. 2011. - Vol. 20 (2). - P. 238-244.

\section{ИЗМЕРЕНИЕ ФИЗИКО-МЕХАНИЧЕСКИХ ХАРАКТЕРИСТИК МЕДИЦИНСКИХ ИЗДЕЛИЙ ДЛЯ ОЦЕНКИ ИХ МАНИПУЛЯЦИОННЫХ СВОЙСТВ}

Наимзада М.Д.3., Липатов В.А.

Курский государственный медицинский университет (КГМУ)

Изучение манипуляционных свойств различных медицинских изделий имеет важное практическое значение в процессе оценки конкурентных и потребительских качеств продукта. для практического применения, так как. Соответствие потребительских свойств (эффективности, безопасности, удобства использования) изделий ожиданиям врачей в наибольшей степени влияет на конкурентоспособность и рыночный успех. Данные свойства обеспечивают В исследованиях гемостатических аппликационных материалов мы выбрали ряд преимуществ для данных изделий: важнейших характеристик для средств хирургического назначений:

- удобство использования медицинских изделия в практической медицине 
- универсальность (возможность применения изделий в различных областях медицины хирургии и при различных локализациях патологических процессов).

- соответствие современным и глобальным трендам (возможность использования изделий в условиях малоинвазивной малоинвазивных вмешательств и пр.).хирургии.

Манипуляционные свойства представляют собой не просто набор характеристикотдельных измеримых свойств изделий, но набор характеристик, индивидуальный для каждого определённого вида медицинских изделийсредств. Так, для изучения манипуляционных свойств хирургических нитей имеют значение такие их физико - механические характеристики как их растяжимость, прочность, коэффициенты трениякапиллярность, фитильность и некоторые другиепр. А для изучения манипуляционных свойств хирургических игл важными являются следующие их характеристики: способность упруго деформироваться, стойкость к износу, проникающая способностьострота режущих краев, качество изготовления соединения иглы с нитью и так далее.

Таким образом, исходя из предыдущего тезиса, можно сделать вывод о том, что целесообразной является разработка наборов тестов для определения физикомеханических свойств для каждого определённого вида медицинских изделий в зависимость зависимости от области их практического применения, требований, предъявляемых к данному виду изделий.

Важными для оценки манипуляционных характеристик губчатых гемостатических имплантов мы считаем следующие характеристики: остаточная деформация при полном сжатии (ОДС), остаточная деформация при сжатии на 50\% толщины (ОДС 50\%), сорбционная способность, влажность, полная пористость, кажущаяся плотность.

Важность этих характеристик определяется следующим:

- ОДС при полном сжатии позволяет определить скорость восстановления формы губки после механического воздействия на неё путем полного сжатия. Испытание позволяет характеризовать эластичность, способность восстанавливать форму.

- ОДС при сжатии на 50\% толщины даёт возможность определить скорость восстановления формы губки после механического воздействия на неё путем сжатия на $50 \%$ от ее толщины. Исследование аналогично ОДС, но не подразумевает возможного разрушения внутренней структуры изделия.

- сорбционная способность даёт возможность определить массу и объем воды, которую может поглотить гемостатическая губка после выдердивания её в воде и последующего центрифугирования

- влажность даёт представление о содержании воды в исходном, готовом к использованию, образце губки, а так же показывает, какое время необходимо для того, чтобы эта вода испарилась из губки под воздействием температуры 
- полная пористость позволяет определить, суммарную долю объема воздуха в губке. Это важная как с технологической, так и с органолептической стороны характеристика, определяющая текстуру поверхности и плотность образца. какой объёморто-ксилола может поглотить гемостатическая губка после экспозиции губки в орто-ксилола и последующего центрифугирования

- кажущаяся плотностью даёт представления представление о том, каково отношение массы губки ко всему занимаемому этой губкой объёму.

Таким образом, физико-механическое тестирование является важным этапом разработки технологии производства губчатых аппликационных гемостатических средств и позволяет характеризовать многие конкурентные и пользовательские качества будущего продукта.

\section{Список литературы.}

1. Жуковский, В.А. Особенности технологии получения полипропиленовой хирургической мононити [Текст] / В.А Жуковский, В.А. Хохлова, А.В. Гриднева, С.Ю. Коровичева // Пластмассы со специальными свойствами: межвуз. сб. научн. тр. - 2006. - С. 122-124.

2. Жуковский, В.А. Полимерные эндопротезы для герниопластики: монография [Текст] / В.А. Жуковский. - СПб.: Эскулап, 2011. - 104 с.

3. Липатов В.А. и др. Физико-механические и структурные свойства имплантатов, предназначенных для операций на магистральных сосудах // Фундамент. исслед. 2015. № 11. C. $92-98$.

4. Нетяга, А.А. Обоснование применения новых синтетических материалов для пластики брюшной стенки [Текст]: автореф. дис....канд. мед. наук / А.А. Нетяга. - Курск, 2002. - 22 с.

5. Тихонова, О.А. Сравнительный анализ применения сетчатых имплантатов в лечении грыж живота [Текст] : автореф. дис....канд. мед. наук / О.А. Тихонова. - Великий Новгород, 2004. - 20 C.

6. Майстренко А.Н., Бежин А.И., Липатов В.А., Чижиков Г.М. Определение объема кровопотери при моделировании травм паренхиматозных органов с аппликацией новых гемостатических средств в эксперименте // Innova. - 2018. - №11 (2). - C. 12-14. 
ИЗУЧЕНИЕ ВЛИЯНИЯ РАЗЛИЧНЫХ ОБРАЗЦОВ ГЕМОСТАТИЧЕСКИХ ИМПЛАНТОВ НА СВЕРТЫВАЕМОСТЬ КРОВИ В ЭКСПЕРИМЕНТЕ IN VITRO

\author{
Липатов В.А.(1,2), Сотников К.А.(3), Косоголов М.В.(1), Писковитина \\ С.Г.(1), Гладнева С.Ю.(1), Пучкова Е.Л.(1), Шалаев М.А.(1)
}

Курский государственный медицинский университет (КГМУ)

(1) Кафедра оперативной хирургии и топографической анатомии

(2) Лаборатория экспериментальной хирургии и онкологии Научно-исследовательского института экспериментальной медицины

(3) ГБУЗ г. Москвы ГКБ имени С.П. Боткина Департамента Здравоохранения г. Москвы

Повреждение паренхиматозных органов всегда сопровождается обильным кровотечением и поэтому является наиболее опасном среди травм брюшной полости. В абдоминальной хирургии для уменьшения числа осложнений, связанных с кровопотерей, активно внедряются гемостатические материалы местного действия [1]. Такая тенденция привела к разработке большого числа аппликационных гемостатических имплантов различного состава $[3,4]$. В связи с этим возникает необходимость в тестировании и апробации эффективности данных средств как в опытах in vivo, так и в лабораторных условиях.

Целью настоящего исследования является изучение гемостатической активности различных аппликационных кровоостанавливающих средств в опыте in vitro.

Материалы и методы. Оценку эффективности гемостатических имплантов проводили исследуя влияние образцов на образование сгустка согласно разработанной методике. В стерильных условиях кровь у 10 здоровых доноров-добровольцев с письменного согласия, соблюдая правила асептики и антисептики, для исследования забирали из локтевой вены в вакутайнер, содержащий 3,2\% раствор цитрата натрия. После чего произвели рекальцификацию стабилизированной цитратом крови, добавив к 0,5 мл цитратной крови 0,1 мл раствора тромбопластина и 0,1 мл 5\% раствора кальция хлорида. Далее кровь из пробирки дозировали микропипеткой в объеме 200 мкл в кювету коагулометра АПГ2-02-П, в которую после этого помещали стальной шарик и вносили тестируемые образцы различных хирургических материалов стандартного размера (цилиндрической формы с диаметром 0,5 см и высотой 0,2 см). Таймер коагулометра запускали вручную, после установки кювет в измерительные ячейки аппарата согласно инструкции, прилагаемой к АПГ2-02-П. Также учитывали время от начала рекальцификации крови [2]. Исследования проводили на образцах: №1 - губка на основе натриевой соли карбоксиметилцеллюлозы (КМЦ) без модификации; №2 губка на основе натриевой соли карбоксиметилцеллюлозы (КМЦ) термостабилизированная $\left(120^{\circ} \mathrm{C}, 10\right.$ минут в сухожаровом шкафу), а также на образцах обладающих, согласно данным 
производителя, гемостатическим эффектом: губка гемостатическая коллагеновая. С кровью каждого донора произвели по 4 опыта. Обработка результатов исследования производилась помощью электронных таблиц MicrosoftExcel 2010. Достоверность различий средних величин оценивалась с помощью критерия Манна-Уитни. В результате проведенного исследования полученные данные указывают на статистически достоверное сокращение времени свертывания при использовании различных образцов гемостатических губок, это свидетельствует о том, что данную методику целесообразно использовать для дальнейшей оценки гемостатических свойств аппликационных гемостатических средств.

\section{Список литературы.}

1. Лазаренко В.А., Липатов В.А., Нетяга А.А., Лазаренко С.В., Северинов Д.А., Сотников К.А. РАЗРАБОТКА СПОСОБА СРАВНИТЕЛЬНОГО ИЗУЧЕНИЯ ВЛИЯНИЯ ХИРУРГИЧЕСКИХ МАТЕРИАЛОВ НА ПРОЦЕСС ОБРАЗОВАНИЯ СГУСТКА КРОВИ IN VITRО // СОВРЕМЕННЫЕ ПРОБЛЕМЫ НАУКИ И ОБРАЗОВАНИЯ. 2019. №1

2. Липатов В.А., Лазаренко С.В., Сотников К.А., Северинов Д.А. Ершов М.П. К ВОПРОСУ О МЕТОДОЛОГИИ СРАВНИТЕЛЬНОГО ИЗУЧЕНИЯ СТЕПЕНИ ГЕМОСТАТИЧЕСКОЙ АКТИВНОСТИ АППЛИКАЦИОННЫХ КРОВООСТАНАВЛИВАЮЩИХ СРЕДСТВ // НовостИ ХирУргиИ. 2018. №1

3. Бледнов А.В. Перспективные направления в разработке новых перевязочных средств // Новости хирургии. 2006. Т. 14. №. 1. С. 9-19.

4. Бояринцев В.В., Юдин А.Б., Назаров В.Б., Самойлов А.С., Фрончек Э.В., Коваленко Р.А. Доклиническая оценка эффективности местных гемостатических препаратов (экспериментальное исследование) // Медицина катастроф. 2010. №. 3. С. 23-25.

5. Липатов В.А., Северинов Д.А., Саакян А.Р. Локальные гемостатики в хирургии XXI BEКА (обзор литературы)// Innova. 2019. №1 (14). С. 16-22.

\section{ИЗУЧЕНИЕ ВЛИЯНИЯ РАЗЛИЧНЫХ ОБРАЗЦОВ ГЕМОСТАТИЧЕСКИХ ИМПЛАНТОВ НА ТКАНИ В ЭКСПЕРИМЕТЕ IN VIVO \\ Гладнева С.Ю., Писковитина С.Г., Косоголов М.В., Драговоз И.С., Пучкова Е.Л., Шалаев М.А., Липатов В.А.}

Курский государственный медицинский университет 
В современной медицине существует множество способов остановки паренхиматозных кровотечений как системного, так и местного действия. Гемостатические губки и импланты все эффективнее внедряются в клиническую практику как средства местного действия. Создаются образцы с использованием химических или органических основ, к которым могут быть добавлены различные препараты. Такие вариации могут влиять не только на эффективность остановки паренхиматозного кровотечения, но и на изменение реакции окружающих тканей в положительную сторону или полное ее отсутствие.

Любой материал, попадающий в организм в ходе оперативного вмешательства, является чужеродным, а значит провоцирует реакцию тканей.

Целью данного исследования является изучение реакции тканей на подкожно имплантированные гемостатические губки.

Материалами для исследования были выбраны следующие образцы гемостатических имплантов:

образец №1 - губка на основе натриевой соли карбоксиметилцеллюлозы (КМЦ) без модификации;

образец №2 - термостабилизированная губка на основе натриевой соли карбоксиметилцеллюлозы (КМЦ). Термическая обработка проводилась в сухожаровом шкафу при $120^{\circ} \mathrm{C}, 10$ минут.

образец №3 - губка гемостатическая коллагеновая, обладающая, согласно данным производителя, гемостатическим эффектом.

Методы исследования. В опыте in vivo, проведенном на крысах линии Вистар, под ингаляционным наркозом (изофлуран) в условиях операционной с соблюдением правил асептики и антисептики проводился линейный срединный разрез по линии позвоночника. Тупым методом формировался карман в подкожной клетчатке, в который имплантировались образцы размером $1.5 \times 1.5 \mathrm{~cm}$. После этого раны ушивали с захватом мышечной ткани. Для получения достаточной выборки было проведено 36 опытов. Крыс выводили из эксперимента на 3, 7 и 14 сутки путем передозировки наркозом. Далее для приготовления гистологических препаратов выделяли кожу и подкожную клетчатку, которые находились в местах имплантации губок. Приготавливались 2 вида срезов с окрасками гематоксилином и эозином и по методу Ван Гизон. Полученные микропрепараты анализировали под электронным микроскопом ув. х200, х400. В ходе исследования удалось определить реакцию ткани на различные образцы гемостатических имплантов в сравнительном аспекте на разных сроках. Обработка результатов исследования производилась помощью электронных таблиц MicrosoftExcel 2010 с расчетом критерия Манна-Уитни, с допустимым показателем ошибки не более $5 \%$ $(p<0,05)$.

В результате проведенного исследования полученные данные указывают на то, что образец 2 имеет более плотную структуру, тем самым вызывая большее воспаление на 
начальных сроках, в отличие от других образцов. Так же он гораздо дольше резорбируется, что позволяет получить пролонгированное действие препарата. А это свойство достаточно актуально и перспективно для дальнейшего исследования.

\section{Список литературы.}

1. Лазаренко В.А., Липатов В.А., Нетяга А.А., Лазаренко С.В., Северинов Д.А., Сотников К.А. РАЗРАБОТКА СПОСОБА СРАВНИТЕЛЬНОГО ИЗУЧЕНИЯ ВЛИЯНИЯ ХИРУРГИЧЕСКИХ МАТЕРИАЛОВ НА ПРОЦЕСС ОБРАЗОВАНИЯ СГУСТКА КРОВИ IN VITRО // СОВРЕМЕННЫЕ ПРОБЛЕМЫ НАУКИ И ОБРАЗОВАНИЯ. 2019. №1

2. Липатов В.А.Лазаренко С.В.Сотников К.А. Северинов Д.А. Ершов М.П. К ВОПРОСУ О МЕТОДОЛОГИИ СРАВНИТЕЛЬНОГО ИЗУЧЕНИЯ СТЕПЕНИ ГЕМОСТАТИЧЕСКОЙ АКТИВНОСТИ АППЛИКАЦИОННЫХ КРОВООСТАНАВЛИВАЮЩИХ СРЕДСТВ // НовОстИ ХИрУргИИ. 2018. №1

3. Луцевич О. Э., Гринь А.А., Бичев А.А., Шепелев В.В. Особенности применения гемостатических материалов местного действия в хирургии// Московский хирургический журнал. 2016. №3(1). С.12-20.

4. Липатов В.А., Северинов Д.А., Саакян А.Р. Локальные гемостатики в хирургии XXI BEКА (обзор литературы)// Innova. 2019. №1 (14). С. 16-22.

5. Майстренко А.Н., Бежин А.И., Липатов В.А., Чижиков Г.М. Определение объема кровопотери при моделировании травм паренхиматозных органов с аппликацией новых гемостатических средств в эксперименте // Innova. 2018. №11 (2). С. 12-14.

\section{ИННОВАЦИОННЫЕ ТЕХНОЛОГИИ В ЛЕЧЕНИИ ОСТРОГО АППЕНДИЦИТА У БЕРЕМЕННЫХ}

Петрашенко И.И.

\section{ГУ «Днепропетровская медицинская академия МЗ Украины»}

Диагностика и лечение острого аппендицита во время беременности остаются одной из ключевых задач клинической медицины. Накопленный в последние годы навык плановых видеолапароскопических вмешательств и неплохие итоги лечения считаются посылами для постепенного внедрения свежих технологий в ургентную хирургию в различные сроки беременности. По сведениям многих литературных источников видеолапароскопия на различных сроках беременности неопасна и выполнима. Так на поздних сроках беременности идентично нередко применяются как игла Вереша, так и открытая техника (Hasson) $[3,4,5]$. Вместе с тем, при анализе осложнений видеолапароскопии показано, что частота осложнений при применении вышеуказанных способов схожа. Безопасность видеолапароскопии определена, в первую очередь, 
выбором точек и техникой введения инструментов $[5,6]$. Техническое выполнение лапароскопии во 2-ом и 3-ем триместре связано с неудобствами осмотра брюшной полости, с угрозой повреждения беременной матки иглой Вереша, угрозой острой гипоксии и гибели плода. В этом случае советуют открытую лапароскопию Hasson $[1,2,7]$. Но вероятный риск развития осложнений при видеолапароскопии, недостаток данных о воздействии карбоксиперитонеума на организм матери и плода, отсутствие современных протоколов и стереотипов использования оставляют внедрение видеолапароскопии при остром аппендиците у беременных актуальной задачей хирургии $[1,5,7]$.

Цель исследования. Определение технических критериев и оценка безопасного проведения видеолапароскопической аппендэктомии на фоне беременности.

Материал и методы исследованния. В период с 2015 по 2019 годы в хирургическую клинику были доставлены 75 беременных (в сроках от 4-5 до 35-36 недель) с острым

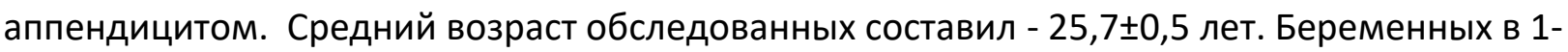
ом триместре было 26 (34,7 \%), во 2-ом триместре - 34 (45,3 \%) и в 3-ем триместре - 15 $(20,0 \%)$ человек.

Вмешательства производились с использованием эндовидеохирургического набора «Olympus» OTV-SC. Операции проведены под внутривенным обезболиванием с искусственной вентиляцией легких эндотрахеальным методом. Внутрибрюшное давление поддерживали на уровне 10-12 мм рт. ст. У всех беременных исследовали результаты антенатальной кардиотокографии, которую делали накануне и после оперативного вмешательства. Сердцебиение плода в антенатальном периоде регистрировали на фетальном мониторе «Corometrics 170 Series».

Результаты исследования и их обсуждение. Видеоапароскопическую аппендектомию выполняли из 3-х троакарных доступов. Постановка троакаров зависела от срока гестации. Впоследствии установления показаний к лапароскопической аппендэктомии вводились вспомогательные троакары. У пациенток в 1-ом триместре беременности расположение троакаров, как правило, было обычное: 2-й диаметром 5-10 мм - в левой подвздошной области, или же - на середине от пупка до лона, 3-й диаметром 5 мм - в проекции червеобразного отростка.

С увеличением срока гестации и, соответсвенно, объема матки начиная, примерно, со 2-го триместра использовали способ открытой лапароскопии Hasson и 1-ый троакар вводили в эпигастрии по срединной линии, или же ниже и правее от мечевидного отростка грудины. Троакар во всех случаях вводили перпендикулярно фронтальной брюшной стене дозированным надавливанием и вращением до ощущения прокола сквозь апоневроз, вслед за тем направление продвижения меняли параллельно дну матки в сторону правого подреберья. Чем более срок беременности, то поближе к правому подреберью помещали один из портов. Карбоксиперитонеум у пациенток доводили до величины 1012 мм. рт. ст. Считаем, что внедрение такового инсуффляционного давления считается больше щадящим и безвредным, в то же время необходимым для важного операционного обзора и выполнения видеолапароскопических манипуляций. Данная 
тактика не оказывала негативного воздействия на организм беременной и не вызывала явлений ацидоза у плода. Подобный объем газа разрешает минимизировать отрицательное воздействие массивного карбоксиперитонеума на организм и очень максимально приблизить функционирование актуально важных систем беременной к пределам физиологических общепризнанных норм.

Послеоперационный этап у всех беременных с острым аппендицитом характеризовался гладким течением. Осложнений со стороны брюшной полости не было, в одном случае наблюдалась серома в области послеоперационной раны. Явлений опасности прерывания беременности не отмечалось. Тест характеристик кардиотокографии, выполненной после видеолапароскопической аппендэктомии, не выявил патологии фетоплацентарной системы. Выписка беременных состоялась на 3-4 день после операции под наблюдение врача женской консультации. Лапароскопическая аппендэктомия у беременных неопасна для матери и плода по причине ее малой инвазивности. Доказательством вышесказанного считаются итоги родоразрешения беременных. У 70 (93,3\%) обследованных беременность завершилась физиологическими родами в сроки от 37 до 40 недели. Новорожденные появились с оценкой по шкале Апгар от 7 до 9 баллов, массой от 2700 до 3650 гр. Острого или же приобретенного респираторного дистресса плода не наблюдалось, не выявлена также задержка внутриутробного развития плода. По акушерским показаниям 2 (2,7\%) женщинам выполнено кесарево сечение, которое никоим образом не было связано с перенесенной лапароскопической аппендэктомией. У 3 (4,0\%) - беременность пролонгирует, при ультразвуковом исследовании патология плодов не установлена.

Выводы. Описанная нами схема выбора точек введения инстументов в зависимости от триместра беременности считается оптимальной, неопасной и дала возможность избежать травм органов брюшной полости и матки.

Внутрибрюшное давление до 10 - 12 мм рт. ст. при аппендэктомии у беременных считается щадящим, приводит к наименьшему травматизму клеточных структур, быстрому восстановлению нарушенных функций организма беременной, способствует благоприятной пролонгации беременности в послеоперационном периоде.

Эндовидеохирургический способ вмешательства разрешает понизить риск раннего прерывания беременности, сводит до минимума послеоперационные осложнения, связанные с заживлением ран, гарантирует невысокую травматичность, не способствует негативному воздействию на беременность, роды и новорожденных.

\section{Список использованной литературы.}

1. Диагностика и лечение острого аппендицита у беременных / И.А. Журавлев, А.Р. Нуриева, О.К. Мамедова, А.А. Фарахутдинов // Вестник Башкир. гос. ун-та. Приложение. 2015. - №2. - C.780-785. 
2. Диагностический алгоритм при остром аппендиците у беременных /С.В. Доброквашин, А.Г. Измайлов, Д.Е. Волков, С.Л. Демьянов// Вестник соврем. клинич. Медицины. - 2013. T.6, №5. - С.83-85.

3. Опыт лечения беременных пациенток с острой хирургической патологией / В.А. Бондаренко, М.В. Турбин, О.Л. Дегтярев, О.Г. Журавлев, А.А. Колесниченко // Эндоскопическая хирургия.-2013.-№1.-С. 143-144.

4. Acute appendicitis in pregnancy / S. Sushma S, J. Prashant, G. Linge, M.N. Shilpa [et al.] // IJBR. - 2014. - Vol.5, N1. - P.63-65.

5. Erkek A. Location of the appendix at the third trimester of pregnancy: A new approach to old dilemma/ A. Erkek, G. Anik Ilhan, B. Yildizhan// J. Obstet. Gynaecol. - 2015. - Vol.35.N 7. - P. 688-690.

6. Jayalall J.A. Role of Laparoscopy in the Management of Acute Abdomen in Pregnancy / J. A. Jayalal1, S.A. Sarasam // Int. J. Scientific Study. - 2015.- Vol 3, N 3. - P.48-54.

7. Kwon C. Y. Could laparoscopic appendectomy in pregnant women affect obstetric outcomes? A multicenter study / C. Y. Kwon, J. H. Park, K. H. Pak //Int. J. Colorectal Dis. - 2016. - Vol. 31(8) - P. 1475-81.

\section{ИССЛЕДОВАНИЕ ВЛИЯНИЯ ГЕМОСТАТИЧЕСКИХ ИМПЛАНТОВ НА ПРОДОЛЖИТЕЛЬНОСТЬ КРОВОТЕЧЕНИЯ В ЭКСПЕРИМЕНТЕ IN VIVO Липатов В.А., Писковитина С.Г., Косоголов М.В., Гладнева С.Ю.} Курский государственный медицинский университет

Среди травм органов брюшной полости, учитывая сложность диагностики и лечения, наиболее опасными являются повреждения печени и селезенки[1]. Тяжесть состояния определяется объемом кровопотери, поэтому обеспечение адекватного гемостаза является главной задачей при оказании помощи [3]. Наиболее перспективным методом осуществления местного гемостаза являются аппликационные гемостатические средства $[4,5]$. Эффективность данного метода определяется физическими свойствами и химическим составом.

Цель работы: изучить в условиях эксперимента изменение времени паренхиматозного кровотечения у крыс при имплантации образцов гемостатических губок. Материалы и методы. Сравнительному анализу гемостатической активности были подвергнуты следующие гемостатические материалы: губка гемостатическая губка из натрий карбоксиметилцеллюлозы «образец №1» и термостабилизированная губка из натрий 
карбоксиметилцеллюлозы «образец №2», гемостатическая коллагеновая губка (производитель: ОАО «Лужский завод «Белкозин», г. Луга, Россия) «образец №3». Эксперименты выполнены на 32 белых крысах-самцах линии Wistar, массой 180-200 гр. В эксперименте использовали животных без внешних признаков заболевания, содержавшихся в одинаковых условиях. Животным была выполнена срединная лапаротомия, после чего выполняли краевую резекцию паренхиматозного органа [6]. На область разреза накладывали исследуемое гемостатическое средство, соответствующих размеров с известной массой. Объем кровопотери оценивали по методу Е.М.Левитэ путем определения разницы стерильного материала до операции и после его пропитывания кровью в ходе операции [2]. Продолжительность кровотечения оценивали визуально, фиксировали секундомером. После проведения операции животные были выведены из эксперимента путем передозировки наркоза. Обработка результатов исследования проводилась с помощью электронных таблиц MicrosoftExcel 2010. Вычислялись средние величины количественных показателей и их средние ошибки. Достоверность различий средних величин оценивалась с помощью критерия МаннаУитни. Полученные данные определяли в виде $\mathrm{M} \pm$ м. Результаты считали статистически значимыми при $р \leq 0,05$.

В результате исследования было выявлено, что термостабилизированная гемостатическая губка («образец №2») действительно сокращает время свертывания крови при травме печени по сравнению с губкой гемостатической («образец №3») на 25\%, а при травме селезенки на 50\%. Это дает основание для дальнейших исследований лечебных свойств термостабилизированных имплантов в хирургии.

\section{Список литературы.}

1. Бежин А.И., Липатов В.А., Майстренко А.Н., Нетяга А.А., Рыжов А.С., Северинов Д.А. Разработка и апробация в эксперименте хирургических имплантов: одно из направлений научных исследований кафедры оперативной хирургии и топографической анатомии имени профессора А.Д. Мясникова Курского государственного медицинского университета. Современные проблемы науки и образования. 2019;2.

2. Лазаренко В.А., Липатов В.А., Нетяга А.А., Лазаренко С.В., Северинов Д.А., Сотников К.А. Разработка способа сравнительного изучения влияния хирургических материалов на процесс образования сгустка крови in vitro. Современные проблемы науки и образования. 2019;1.

3. Кобелевская НВ. Современные аспекты лекарственной гемостатической терапии. Вестн Последиплом Мед Образования.2014;(3):5-9.

4. Чередников ЕФ, Кашурникова МА, Романцов МН, Баранников СВ, Болховитинов АE, Гапоненков ДГ, Любимов ПЮ. Экспериментальное изучение новых средств местного гемостаза в лечении язвенных кровотечений. Науч-Мед Вестн Центрального Черноземья. 2016;(65):27-33. 
5. Луцевич О. Э., Гринь А.А., Бичев А.А., Шепелев В.В. Особенности применения гемостатических материалов местного действия в хирургии.Московскийхирургическийжурнал. 2016; 3(1):12-20

6. Майстренко А.Н., Бежин А.И., Липатов В.А., Чижиков Г.М. Определение объема кровопотери при моделировании травм паренхиматозных органов с аппликацией новых гемостатических средств в эксперименте // Innova. 2018. №11 (2). C. 12-14.

\section{ИССЛЕДОВАНИЕ РЕАКЦИИ ТКАНЕЙ ПЕЧЕНИ НА НОВЫЕ ОБРАЗЦЫ ПОЛИМЕРНЫХ КРОВООСТАНАВЛИВАЮЩИХ МАТЕРИАЛОВ Липатов В.А., Лазаренко С.В., Северинов Д.А.}

\section{Курский государственный медицинский университет, Курск, Россия}

В XXI веке состояние больного с травмой печени в 75\% случаев осложняется развитием шока. Диапазон методов остановки кровотечения из паренхиматозных органов продолжает расширяться и в настоящее время. Среди них выделяют недавно разработанные методики, такие как сдавление печеночно-дуоденальной связки кетгутовой сеткой, наложение гемостатических швов, применение кровоостанавливающих имплантов различного химического состава, фармакологические методы гемостаза, а также резекции участка печени. Цель исследования заключается в оценке гистологических особенностей печени при использовании новых образцов полимерных кровоостанавливающих материалов в эксперименте in vivo. Материалы и методы. В качестве материала исследования были использованы кровоостанавливающие губки на основе натрий-карбоксиметилцеллюлозы (Na-KMЦ), разработанные совместно с ООО «Линтекс», г. Санкт-Петербург, Россия, с добавлением различных лекарственных средств (таких как аминокапроновая - группа №4, ацетилсалициловая - группа №5 и аминоуксусная кислоты - группа №6) и гемостатические коллагеновые губки производства ОАО «Белкозин», г. Луга, Россия - группа №7. Также выделяли следующие группы: группа с моделированием травмы, но без использования материала (№2) и группа, в которой моделирование травмы не проводилось (№1 - контроль). Bсе процедуры на животных проводились под общей ингаляционной анестезией (наркозный аппарат R340 Isoflurane, RWD Life Science, производитель: Hi Tech North Rd, Nanshan Dist., Китайская Народная Республика), концентрация изофлюрана (производитель: AO «Бакстер», США) во вдыхаемой газовой смеси - 3\%, поток воздуха $-0,8$ л/мин) с соблюдением международных и отечественных норм гуманного обращения с лабораторными животными. Лабораторным животным под общим обезболиванием производили срединную лапаротомию, моделировали поверхностную травму печени. Паренхиматозное кровотечение останавливали наложением тестируемых материалов. Производили аутопсию травмированного участка печени вместе с имплантированным 
гемостатическим средством на 14 сутки после эксперимента. По стандартной методике изготавливали парафиновые блоки и гистологические микропрепараты, которые окрашивали гематоксилином и эозином. Производили микроскопирование (увеличение 40 крат) - медицинский микроскоп МИКМЕД-6 (производитель АО «ЛОМО», г. СанктПетербург, Россия) и фотографирование с помощью C-mount (резьбовое соединение типа C) камеры Е3CMOS12000KPA на основе сенсора Sony IMX226. На полученных микрофотографиях измеряли (в пикселях - px) толщину капсулы, размер центральных вен печени, площадь гепатоцитов и их ядер, а также количество двухъядерных гепатоцитов. Для определения достоверности отличий средних применяли критерий Даннета $(p \leq 0,05)$. Результаты исследования. Показатель площади гепатоцитов групп №4 и № 5 максимально приближены к показателям группы №1. Аналогично площади гепатоцитов, различие площади их ядер в группах №6, №7 статистически незначимы по сравнению с группой №1. В группах №6 и № 5 площадь ядер достоверно увеличена, но не достигает значений контрольной группы. Наибольшее статистически значимое увеличение толщины капсулы по сравнению с группой № 1, группой №2 и №3 наблюдалось в группе №4. Площадь центральной вены достоверно увеличена по сравнению с контрольной группой в группах №2, №3 и №6. Количество двуядерных гепатоцитов по сравнению с нормой, группой №4 и группой №1 достоверно выше в группах №6 и №7. Изменения морфологической структуры в местах травмы и имплантации тестируемых образцов менее выражены при использовании гемостатических имплантов экспериментальных групп №3-№6 (кровоостанавливающие локальные средства на основе Na-КМЦ с добавлением аминокапроновой, ацетилсалициловой и аминоуксусной кислот).

\section{Список литературы.}

1. Липатов В.А., Лазаренко С.В., Сотников К.А., Северинов Д.А., Ершов М.П. К вопросу о методологии сравнительного изучения степени гемостатической активности аппликационных кровоостанавливающих средств. Новости хирургии. 2018; №1(26): С. 8195. doi: 10.18484/2305-0047.2018.1.81

2. Biçer M., Bayram A.S., Gürbüz O. et al. Assessment of the efficacy of bio-absorbable oxidized regenerated cellulose for prevention of post-operative pericardial adhesion in the rabbit model. Journal of International Medical Research. 2008; № 36: P. 1311-1318. doi: 10.1177/147323000803600619.

3. Бежин А.И., Липатов В.А., Майстренко А.Н., Нетяга А.А., Рыжов А.С., Северинов Д.А. Разработка и апробация в эксперименте хирургических имплантов: одно из направлений научных исследований кафедры оперативной хирургии и топографической анатомии имени профессора А.Д. Мясникова Курского государственного медицинского университета. Современные проблемы науки и образования. 2019; 2.

\section{4. Липатов В.А., Северинов Д.А., Саакян А.Р. Локальные гемостатики в хирургии XXI BEКА} (обзор литературы)// Innova. 2019. №1 (14). С. 16-22 
5. url: http://www.science-education.ru/ru/article/view?id=28680 (дата обращения: 31.03.2019). https://doi.org/10.17513/spno.28680

6. Sampanis D., Siori M. Surgical use of fibrin glue-coated collagen patch for nonhemostatic indications. European surgery. 2016; Vol. 48: № 5: P. 262-268. doi: 10.1007/s10353016-0436-y.

7. Grimm C., Polterauer S., Helmy S., et al. A collagen-fibrin patch (Tachosil ${ }^{\circledR}$ ) for the prevention of symptomatic lymphoceles after pelvic lymphadenectomy in women with gynecologic malignancies: a randomized clinical trial. BMC Cancer. 2014; № 14: P. 635-642. doi:10.1186/1471-2407-14-635.

\section{КОРРЕКЦИЯ СИНДРОМА ЭНТЕРАЛЬНОЙ НЕДОСТАТОЧНОСТИ В КОМПЛЕКСНОМ ЛЕЧЕНИИ БОЛЬНЫХ С ПЕРИТОНИТОМ \\ Ильченко Ф. Н., Гончарук В. А., Гривенко С. Г.}

Медицинская академия им. С. И. Георгиевского ФГАОУ ВО «КФУ им. В.И. Вернадского»

Ведущая роль в развитии и прогрессировании перитонита принадлежит энтеральной недостаточности (ЭН), которая возникает в 90-100\% случаев и является ключевым фактором эндогенной интоксикации - основной причины неблагоприятных исходов [1]. При этом разрушается система эндотоксинового иммунитета, что означает не только избыток липополисахарида (ЛПС) в гемоциркуляторного русле, но и активацию участия кишечного энтеротоксина в физиологических процессах. В связи с этим в комплексной терапии перитонита важное место занимают различные способы детоксикации, в том числе сорбционной [2].

Цель работы - оценка эффективности применения энтеросорбции и антигипоксанта в коррекции ЭН по предложенному способу при комплексном лечении перитонита.

Материалы и методы. Все обследованные больные (74 пациента с перитонитом различной этиологии) были разделены на две группы. В первую группу были включены 43 пациента, которым применили предложенный способ коррекции ЕН [3], во вторую - 31 пациент, которым проводилась традиционная детоксикационная терапия. Группу сравнения составили 32 практически здоровых человека. Эффективность предложенного способа оценивали по мониторингу антиендотоксинових (АЭТ) антител, специфичных к лПC Escherichia coli K 30. Материалом для исследований служила сыворотка крови, которую получали общепризнанным методом, где определяли антитела классов $\mathrm{A}, \mathrm{M}$ и $\mathrm{G}$ (соответственно, анти-ЛПС-IgA, анти-ЛПС-IgМ, и анти-ЛПС-IgG) методом твердофазного иммуноферментного анализа [4]. Исследование проводили до операции, и в сроки: 1-3-и и 8-10-е сутки в послеоперационном периоде. 
Результаты. До операции уровень значений показателей анти-ЛПС-IgA и анти-ЛПС-IgG достоверно увеличивался по сравнению с нормой, а анти-ЛПС-IgM, напротив, снижался. На 1-3 сутки после операции в обеих группах происходило падение уровней АЭТ антител всех классов относительно значений до операции. При этом во второй группе пациентов, снижение значений показателей АЭТ иммунитета было выражено в большей степени. На 8-10 сутки после операции диагностирован рост содержания АЭТ антител классов A и G относительно показателей до операции и в сроки 1-3 сутки. Однако в большей степени это было характерно для больных второй группы, что свидетельствует о повышении напряженности АЭТ иммунитета вследствие повышенной антигенной стимуляции иммунной системы эндотоксинами на фоне пареза кишечника и бактериальной транслокации. К 1-3 суткам послеоперационного периода имеет место дефицит специфических антител вследствие их повышенного потребления после хирургического вмешательства. Однако он более выражен у больных второй группы. В сроки 8-10 сутки после операции в обеих группах, наоборот, тенденция к повышенной напряженности АЭТ иммунитета, в большей степени во второй группе, что указывает на сохранение в эти сроки синдрома ЭН.

Таким образом, предлагаемый способ является эффективным в предупреждении и коррекции ЭН в комплексном лечении больных с перитонитом и может найти применение в широкой хирургической практике.

\section{Список литературы.}

1. Косинец В. А. Синдром энтеральной недостаточности: патогенез, современные принципы диагностики и лечения / В. А. Косинец // Новости хирургии. - 2008. - Т.16, №2. - С. 130-138.

2. Ранняя энтеральная послеоперационная иммунокоррекция модифицированным пектинсодержащим препаратом при перитоните / Д. А. Демидов, М.В.Костюченко, М. В. Мешков, Л. А. Дуденко // Экспериментальная и клиническая гастроэнтерология. - 2009. №6. - С. 61-67.

3. Спосіб корекції ентеральної недостатності в комплексному лікуванні хворих 3 перитонітом : пат. 132398 Украина, МПК (2006) A61P 17/18 (2006.01) A61P 1/16 (2006.01) А/61К 31/00 А61B 17/00 / Ф. М. Ільченко, В. А. Гончарук, С. Г. Гривенко. - № u2019 09406 ; заявлено 17.09.18; опубл. 25.02.19, Бюл. №4. - 5с.

4. Уровни естественных антител к липополисахаридам энтеробактерий у постоянных доноров республики Крым / А. И.Гордиенко, А. А. Бакова, Н. В. Химич, В. А. Белоглазов // Імунологія та алергологія. - 2003. - №4. - С. 31-36. 


\section{МЕДИЦИНСКАЯ ЭТИКА КАК ОСНОВА ВРАЧЕБНОЙ ПРАКТИКИ В.Ф.ВОЙНО-ЯСЕНЕЦКОГО \\ Гуреева А.В., Авдеева Е.В.}

Курский государственный медицинский университет

Работа врача - это уникальный процесс, где очень многое определяет любовь к человеку и стремление облегчить его страдания. Перед врачом в силу профессиональной специфики открываются скрытые грани человеческой сущности, которые касаются не только анатомии и физиологии, но и психологии человека. Человек, ожидающий помощи, доверяет врачу, порой исповедуясь ему, словно священнику.

"В какой бы дом я ни вошел, я войду туда для пользы больного, будучи далек от всего намеренного, неправедного и пагубного", - писал Гиппократ. Отношение врача к человеку в практической деятельности, в своей основе ориентированное на помощь, заботу, поддержку является основой профессиональной врачебной этики. Наблюдательный, опытный доктор способен дать не только медицинские рекомендации, но и совет в плоскости общечеловеческих проблем, тем самым способствуя в ряде случаев формированию мировоззрения, как отдельного человека, так и общественного сознания в целом.

Лучшим представителям отечественной медицины всегда было присуще бескорыстие, глубокий демократизм, гуманное отношение к больным. Образцом данных качеств может служить жизненный путь врача и проповедника Валентина Феликсовича Войно-

Ясенецкого. Как теоретик и практик во врачебной сфере, он уделял большое внимание нравственному поведению врача. Система этических воззрений В.Ф. Войно-Ясенецкого может рассматриваться как возможный подход к построению, как теоретических оснований, так и самой практики медицинской этики [1].

Валентин Феликсович Войно-Ясенецкий родился в Керчи 27 апреля 1877 г. в семье провизора. О медицине будущий «святой хирург» никогда не мечтал. Окончив Киевскую художественную школу и проучившись, год живописи в Мюнхене, он решил: «что обязан заняться тем, что полезно для страдающих людей» и подает документы на медицинский факультет Киевского университета [5].

После выпускных экзаменов в 1903 году Валентин Феликсович заявил о намерении стать земским врачом. Товарищи по курсу недоумевали! А владыка Лука потом признается: «Я был обижен тем, что они меня совсем не понимают, ибо я изучал медицину с исключительной целью быть всю жизнь деревенским, мужицким врачом, помогать бедным людям» [3].

Учиться мастерству оперирования на глазах Валентин Феликсович стал сразу после выпускных экзаменов, зная, что в деревне с ее нищетой свирепствует трахома. Приема в больнице для него оказалось недостаточно, и он стал принимать больных у себя дома. 
Однажды после операции у него прозрел, слепой с раннего детства, молодой нищий. За два месяца к нему пришли слепые со всей округи, и все эти немощные люди пришли к хирургу Войно-Ясенецкому, ведя друг друга за палки [1].

Другим направлением врачебной деятельности Войно-Ясенецкого была разработка методов регионарной анестезии, так как в то время больные зачастую умирали от непереносимости наркоза. Поэтому многие земские врачи отказывались в своей практике или от использования наркоза при операциях, или от самих операций. В 1915 г. в Петрограде вышла книга «Региональная анестезия», в которой В.Ф. Войно-Ясенецкого обобщил и результаты своих исследований, и богатейший опыт хирургической практики [5].

В 1916 г. В.Ф. Войно-Ясенецкий получил степень доктора медицины за монографиюдиссертацию «Регионарная анестезия», и переехал с семьей в Туркестан. Это время было наиболее тяжёлым для советской власти в Туркестане, свирепствовали голод и эпидемии. Несмотря на тяжелую ситуацию, Валентин Феликсович способствовал основанию в конце лета 1919 г. Высшей медицинской школы, где преподавал нормальную анатомию, кроме общественной деятельности, он продолжал лечить людей, в качестве хирурга. В 1920 г. был образован Туркестанский государственный университет, где В. Ф. Войно-Ясенецкий стал возглавлять кафедру оперативной хирургии. Валентин Феликсович представлял пример для своих помощников «человеческой хирургии»: с каждым больным или раненым он общался как с личностью, помнил каждого в лицо, и по фамилию, держал в памяти все подробности не только операции, но и послеоперационного периода. «Тяжело переживаю смерть больных после операции, - писал он сыну. - Было три смерти в операционной, и они меня положительно подкосили... Переношу их все тяжелее и тяжелее...» [4].

В конце 1920 г. несмотря на яростную борьбу с православием, Валентин Феликсович стал священнослужителем. В тоже время, оставаясь главным хирургом Ташкентской городской больницы, по воскресеньям служил в соборе, после вечерни находил время и вел беседы с прихожанами и больными на богословские темы. 31 мая 1923 г. в г. В.Ф. Войно-

Ясенецкий после посвящения стал епископом Ташкентским и Туркестанским. Несмотря на высокую церковную должность Валентин Феликсович не перестал лечить людей, продолжая работать главным врачом больницы, оперируя, руководя кафедрой в медицинском институте и ещё выкраивая время для научных исследований [2].

Являясь священником Русской православной церкви, В.Ф. Войно-Ясенецкий, тем не менее, всю свою жизнь оставался профессором медицины, оперирующим хирургом и общественным деятелем. В 1934 г. несмотря на два ареста со ссылками, увольнение из городской больницы и университета, был опубликован его основной врачебный труд под названием «Очерки гнойной хирургии», явившийся необходимым и актуальным научно-практическим руководством для практикующих врачей в предвоенные и военные годы [4]. 
Во время Великой Отечественной войны профессор Войно-Ясенецкий занимал должность главного хирурга эвакогоспиталей. Вместе с врачебной деятельностью святитель Лука возглавлял духовные кафедры. В 1943 г. было опубликовано второе издание «Очерков гнойной хирургии». В 1946 г. за разработанные им новые хирургические методы лечения гнойных заболеваний В.Ф. Войно-Ясенецкий был удостоен Сталинской премии первой степени [5].

Святитель Лука в своих научных и религиозных трудах не раз поднимал вопрос о том, каким должен быть врач, как профессионал своего дела. Войно-Ясенецкий неустанно повторял, что выбравший профессию врача должен беззаветно любить своего пациента, только тогда, и только тогда возможно быстрое и эффективное его излечение. «Приступая к операции, надо иметь в виду не только брюшную полость, а всего больного человека, который, к сожалению, так часто у врачей именуется «случаем»... Для хирурга не должно быть «случая», а только живой страдающий человек» [2].

В. Ф. Войно-Ясенецкий был гениальным врачом и одаренным проповедником, порой метавшимся между этими двумя призваниями. Трудно дать ему однозначную характеристику. С одной стороны, врач, лечивший обычных людей, с другой - профессор, читавший лекции студентам, с третьей - политзаключенный, прошедший ссылки, тюрьмы и пытки, а впоследствии ставший лауреатом Сталинской премии. С четвертой хирург, избавивший от слепоты сотни людей, а в конце жизни сам потерявший зрение. И при всем при этом - христианин огромной силы воли, честности и безбоязненной веры. Важно отметить, что для хирурга Луки никогда не существовало «медицинского случая», а всегда он видел перед собой живого страдающего человека.

В течение 38 лет своего священнического и архиерейского служения святитель Лука произнёс около 1250 проповедей, из которых 750 записаны и составляют 12 толстых машинописных томов. 22 ноября 1995 г. архиепископ Симферопольский и Крымский Лука был причислен к лику святых православной церкви.

Жизненный путь, мировоззрение, созданные труды святителя Луки являются примером для поколений врачей, и выступают как общее достояние всего человечества.

\section{Список литературы.}

1. Бочкарева А. С., Веселова Д. В., Редько А. Н., Хотина Ю. В. Историко-культурное наследие России.: взаимосвязь работы врача и веры в контексте проблемы рассмотрения жизни и медицинской деятельности Е.С. Боткина и святителя Луки (В.Ф. ВойноЯсенецкого) / А.С. Бочкарева, Д.В. Веселова, А.Н. Редько, Ю.В. Хотина // Известия АлтГУ. Исторические науки и археология. - 2018. - №5. - С. 25-29.

2. Войно-Ясенецкий, В.Ф. Дух, душа и тело Текст. /В.Ф. Войно-Ясенецкий. - Киев, 2002. $152 \mathrm{c}$ 
3. Войно-Ясенецкий, В.Ф. Я полюбил страдание. Автобиография. Текст. /В.Ф. ВойноЯсенецкий. М.: Благодатный огонь, 2000. - 208 с.

4. Войно-Ясенецкий В. Ф. (Архиепископ Лука) Очерки гнойной хирургии. - М. - СПб.: ЗАО «Издательство БИНОМ», «Невский Диалект», 2000 - 704 с.

5. Филиппова М. В. Войно-Ясенецкий, археипископ Лука / М. В. Филиппова // Архивъ внутренней медицины.- 2014.- №6.- С. 68-73.

\section{МИНИИНВАЗИВНАЯ ХИРУРГИЯ В КОМПЛЕКСНОМ ЛЕЧЕНИИ АБСЦЕССОВ ПЕЧЕНИ \\ Григорьев С.Н., Бондарев Г.А., Григорьев Н.Н., Бобровская Е.А., Кононенко К.В.}

\section{Курский государственный медицинский университет, Курская областная клиническая больница}

За последние 10-20 лет отмечен существенный рост заболеваемости желчнокаменной болезнью и острым холециститом (2 - е место после острого аппендицита в структуре острой хирургической абдоминальной патологии), что привело), что привело к значительному увеличению пациентов с абсцессом печени [2].

С внедрением в клиническую практику современных методов интраскопии (ультразвуковые исследования - УзИ, компьютерная томография КТ) - открыли большие возможности для современной диагностики и лечения абсцессов печени $[1,3,4]$.

Цель работы: клинический анализ результатов лечения пациентов с абсцессами печени. Материалы и методы. Были подвергнуты клиническому и инструментальному обследованию 258 пациентов с абсцессами печени.

Среди всех больных мужчины составили 60,1\%, женщины - 39,9\%. Средний возраст пациентов $51,4 \pm 3,2$ года. В результате УЗИ и КТ одиночные абсцессы выявлены у $57,8 \%$ больных, множественные - у 42,2\%. Правая доля печени была поражена в 73,4\% случаев с наибольшей частотой локализации воспалительного процесса в VII сегменте - 32,8\%. Размеры гнойников варьировались от 0,4 до 15 см.

Частыми этиологическими факторами в генезе абсцессов печени наблюдались холангиогенные причины (43,5\%), пилефлебит (14,1\%), инфицированные гематомы 
(12,5\%), нагноившиеся кисты (9,4\%), идеопатические (20,5\%). Сопутствующая патология имелась у $82,8 \%$ больных.

Всем больным проводили антибактериальную и комплексную медикаментозную терапию по протоколам лечения абсцессов печени и абдоминального сепсиса. Перкутанное дренирование под сонографическим мониторингом выполнено у 89,1\% больных. Используемый диаметр дренажей напрямую не зависел от объема полости деструкции, а определялся критериями адекватного дренирования полости и безопасностью проведения хирургического вмешательства. Абсцессы печени, обычно не содержат тканевые секвестры, что позволяет эффективно использовать дренажи №8 Fr. Количество абсцессов печени не является ограничивающим фактором в использовании диапевтических технологий под контролем УзИ.

Санация контактных и холангиогенных абсцессов печени подразумевала следующие моменты: типичную санацию и наружное дренирование гнойной полости и воздействие на причинный фактор - устранение биллиарной обструкции.

Разноуровневая внутрипеченочная желчная гипертензия выявлена у $36,3 \%$ пациентов. Целесообразно не только дренировать холедох, а так же разгрузить сегментарные протоки в зоне формирования абсцессов. При этом считаем оптимальным способом декомпрессии - комбинированную магистральную и сегментарную чреспеченочную холангистомию. При абсцедирование на фоне механической желтухи опухолевого генеза, после санации абсцессов и купировании холангита, предпочтение отдавали использованию чрезкожных наружно - внутренних холедоходуоденальных стентов перед внутренними, учитывая достаточно быструю их окклюзию, трудности последующего извлечения, замены, либо восстановления проходимости внутренних стентов.

При холангиогенных абсцессах печени на фоне механической желтухи, обусловленных «трудными» конкрементами холедоха применяем методику чрескожных холедохо холангиолитолапаксий. При любой степени гипертензии, вне зависимости от уровня обструкции, его длительности и причины, использование чрескожного дренирования желчного дерева при холангиогенных абсцессах является приоритетным, позволяющий с минимальным риском добиться контролируемой билиарной декомпрессии, используя доступ для внутрипросветных вмешательств. После купирования гнойного холангита и санации полостей деструкции созданный малокалиберный доступ трансформировали в доступ большого диаметра с последующей холедохо - холангиолитоэкстракцией. Полноту санации биллиарного дерева контролировали визуально и рентгенологически.

Характер микрофлоры, полученной из полости абсцесса, включал кишечную палочку, стафилококк, синегнойную палочку, энтерококки. Во время дренирования эвакуировали от 10 до 700 мл гноя, при этом менее 50 мл - у 54,7\% больных, от 50 до 100 мл - у 20,3\%, более 100 мл - у 15,6\%. Время стояния дренажей составило 29,5ะ3,5 дня и определялось как характером полости абсцесса (размером, формой, наличием боковых карманов, перемычек и других факторов, затрудняющих санацию), так и исходной тяжестью состояния, наличием сопутствующих заболеваний и/или их осложнений. 
Средняя продолжительность пребывания в стационаре составила $23 \pm 2,3$ дня. В удовлетворительном состоянии были выписаны 28 больных с сохраненным в полости абсцесса дренажом под амбулаторное наблюдение. Дренажи удаляли при отсутствии гнойного отделяемого из полости абсцесса и затеков контраста при контрольной фистулографии, а так же при регенераторном типе цитограмм. Летальных случаев при использовании малоинвазивных технологий у пациентов не наблюдалось.

Таким образом, диапевтические технологии у пациентов с абсцессами печени являются методом выбора и обеспечивают эффективное лечение.

\section{Список литературы.}

1. Ахаладзе, Г.Г. Абсцессы печени / Г.Г. Ахаладзе, И.Ю. Церетелли // Анналы хирургической гепатологии. - 2006. - Т.11. - С.97-105.

2. Клиническая хирургия: учебное пособие для клинических ординаторов и врачей / В.А. Лазаренко, Г.А. Бондарев, Н.Н. Григорьев и др. - Курск, 2017. - 924 с.

3. Малоинвазивная хирургия абсцессов печени / В.А. Лазаренко, С.Н. Григорьев, О.И. Охотников и др. // Сборник трудов 72-й научной конференции КГМУ и сессии Центрально - Черноземного научного центра РАМН. - 2007. - II том. - С.127-129.

4. Пархисенко, Ю.А. Новые направления в лечении при абсцессах печени / Ю.А. Пархисенко, А.А. Глухов // Вестник Хирургии им. И.И. Грекова. - 2000. - Т. 159, №4. - С.5354.

\section{НАУЧНЫЕ ИССЛЕДОВАНИЯ В ОБЛАСТИ МЕДСЕСТРИНСКОГО ДЕЛА Салиходжаева Р.К.}

\section{Ташкентский институт усовершенствования врачей}

Важным звеном в системе здравоохранения является категория средних медицинских работников, от квалификации которых зависят профилактика ряда заболеваний и жизнь человека. Без участия квалифицированного, компетентного сестринского персонала вряд ли возможно выполнение большинства услуг, относящихся к системе первичной медикосанитарной помощи, специализированных помощи и оказание экстренной медицинской помощи. Доступность помощи в этой ситуации должна быть обеспечена для всех категорий населения. Именно медицинская сестра может устранить коммуникативные барьеры в процессе общения с пациентом. Сегодня существенно возрастает роль главных 
и старших медицинских сестер как организаторов деятельности специалистов среднего медицинского звена.

Основная цель подготовка медицинских сестер с высшем образованием - подготовка специалистов, обладающих современными научными знаниями, широким кругозором, организаторскими способностями которые могут проводить медсестринские исследования в области сестринского дела.

Научные исследования в области медсестринского дела подразумевает проведение систематического поиска и анализа, направленных на совершенствование знаний с целью их дальнейшего использования в области медсестринской практики, в образовании и управлении. Важность научных исследований в сестринском деле объясняется целым рядом причин. Наиболее актуальной из них является то, что данные исследования позволяют постоянно улучшать качество работы с пациентом - клиентом медсестринской службы.

Данные исследования также позволяют документально запечатлеть практическое выражение значимости медсестринской деятельности и довести эту информацию до сведения коллег, пациентов и руководителей.

В этом процессе имеет большое значение подготовка медицинских сестёр с высшим образованием в медицинских институтах, которая по 4 направлениям: менеджер; акушерка родильного блока; медсестра операционного блока; медсестра отделения анестезиологии-реанимации.

В Республике у медицинских сестер с высшим образованием, в степени бакалавра помимо работы в учреждениях здравоохранения - поликлиниках, стационарах, преподавания в ВУЗах, колледжах впервые появилась уникальная возможность заниматься научными исследованиями по своей специальности. Введение в сестринское дело научных исследований будет способствовать, во-первых, совершенствованию профессиональной деятельности; во-вторых, обеспечит более высокий уровень оказания сестринской помощи пациентам хирургического профиля. Результаты научных исследований позволят расширить возможность качественного ухода после операционных больных.

Медицинские сестры обязаны в своей практической деятельности руководствоваться выводами, полученными в ходе научных исследований (доказательной медицины) для того, чтобы их действия носили клинически оправданный характер, были экономически эффективными и обеспечивали наиболее качественное удовлетворение потребностей пациента и максимально положительный конечный результат.

Вкладом медицинских сестер, в развитии научно-исследовательской деятельности заключаться в следующем:

В зависимости от уровня профессиональной подготовки, медсестры со степенью бакалавра, могут, изучив теорию процесса научных исследований, регулярно знакомиться 
с результатами новых исследований и уметь критически оценивать возможность использования на практике их результатов. Медсестры со степенью магистра могут разрабатывать и проводить самостоятельные научные исследования. Объединенные усилия медсестер и среднего медицинского персонала хирургического отделений, занимающихся научной работой будут способствовать проведению высококачественных клинических исследований. Медсестры отделений хирургии играют важную роль в определении проблем, требующих научного анализа. Они также могут участвовать в проведении исследований, выполняя рекомендации составленные медсестрами, непосредственно проводящими исследования, организовать рабочие место врачахирурга, контролируя наличие необходимого медицинского инструментария, инвентаря, документации, проверяя исправность аппаратуры и средств оргтехники.

К современной медицинской сестры требует наличия не только профессиональных навыков, но и организаторских способностей и возможностей ведения аналитической деятельности, т.е. выполнения функций менеджера на своей функции. Увеличение объема работы требует проведении многих мероприятий, требующих довольно значительного изменения принципов организации труда медицинской сестры в зависимости от объема и качества оказания медицинской помощи.

В нашей стране сестрам, планирующим применение сестринского процесса в рамках Европейского регионального бюро ВОЗ, рекомендуется использовать модель, учитывающую физиологические, психологические и социальные потребности пациента и его семьи. Использование модели ВОЗ заключается в осуществлении переноса сестринской помощи с состояния болезни на состояние здоровья. Для оказания помощи сестры производят оценку здоровья человека и выясняют потребности его в самопомощи, помощи на дому, профессиональной помощи. В рамках реформы здравоохранения в Республики Узбекистан предстоит утвердить профессиональную идеологию сестринского дела - осуществления сестринского процесса.

Цель сестринского процесса у хирургического пациента заключается в том, чтобы предупредить, облегчить, уменьшить или свести к минимуму проблемы и трудности, возникающие у него.

Такими проблемами и трудностями у хирургических больных являются боль, стресс, диспептические нарушения, расстройства различных функций организма, дефицит самоухода и общения. Постоянное присутствие сестры и контакт с пациентом делают ее основным звеном между ним и внешним миром. Осуществляя уход за хирургическими больными, медицинская сестра видит те чувства, которые испытывают они и их семьи, и выражает сочувствие. Сестра должна облегчить состояние пациента, помочь в выздоровлении.

Способность самоухода у пациентов с хирургической патологией сильно ограничена, поэтому своевременная внимательная сестринская помощь по выполнению необходимых элементов лечения будет первым шагом к выздоровлению. Сестринский процесс дает 
возможность медицинской сестре квалифицированно и профессионально решить проблемы пациента, связанные с его выздоровлением.

Сестринский процесс - это метод организации и оказания сест-ринской помощи. Суть сестринского дела состоит в уходе за человеком и в том, каким образом сестра осуществляет этот уход. В основе этой работы должна лежать не интуиция, а продуманный и сформулированный подход, рассчитанный на удовлетворение потребностей и решение проблемы пациента.

В основе сестринского процесса находится пациент, как личность, требующая комплексного подхода. Одним из непременных условий осуществления сестринского процесса является участие пациента (членов его семьи) в принятии решений относительно целей ухода, плана и способов сестринского вмешательства. Оценка результата ухода также осуществляется совместно с пациентом (членами его семьи).

Научные исследования в области медсестринского дела хирургического профиля подразумевает проведение систематического поиска и анализа, необходимых мероприятий и навыков. Медицинская сестра играет важную роль при лечении пациентов хирургического профиля, в послеоперационный период медицинская сестра определяет план и стратегию, направленную на удовлетворение нужд пациента с учетом его хирургической патологии.

\section{Список литературы.}

1. О ходе реализации отраслевой программы развития сестринского дела в Сибирском федеральном округе Российской Федерации. Сборник научных работ Региональной научно-практической конференции с международным участием. Г. Томск. 15-16 мая 2003 г.

2. Banister, E. M. (1999). Women's midlife experience of their changing bodies. Qualitative Health Research, 9, 520-537.

3. Maguire, D. P. (1999). Skin protection and breakdown in the ELBW infant. Clinical Nursing Research, 8, 222-234.

4. Brooks-Brunn, J. A. (2000). Risk factors associated with postoperative pulmonary complications following total abdominal hysterectomy. Clinical Nursing Research, 9, 27-46.

5. Cohen, M H. (1999). The technology-dependent child and the socially marginalized family: A provisional framework. Qualitative Health Research, 9, 654-668.

6. Polit, D. F., Beck, C. T., й Hungler, B. P. (2001). Essentjals of nursing research: Methods, appraisal, and utilization. New York: Lippincott. 
ОПТИМИЗАЦИЯ ВЕНТРАЛЬНОГО АУТОКОСТНОГО СПОНДИЛОДЕЗА В ХИРУРГИЧЕСКОМ ЛЕЧЕНИИ НЕСПЕЦИФИЧЕСКИХ

СПОНдИЛодисцитов

Гончаров М.Ю.1, Левчик Е.Ю.2

1 Врач-нейрохирург, к.м.н., ГБУз СО «Свердловская областная клиническая больница №1», г. Екатеринбург, ул. Волгоградская 185.

2 Заведующий гнойным хирургическим отделением, дм.н., ГБУЗ СО «Свердловский областной клинический психо-неврологический госпиталь ветеранов войны», г. Екатеринбург, ул. Соболева 25.

Целью нашей работы было улучшение исходов аутокостного спондилодеза при неспецифических спондилодисцитах за счет оптимизации пространственной формы костного трансплантата.

За период с 2005 по 2015 годы на лечение находились 180 пациентов с

неспецифическими гнойными заболеваниями позвоночника. Больные были оперированы в объеме некрсеквестрэктомии тел позвонков и межпозвонковых дисков, с последующим стабилизирующим аутокостным спондилодезом. Все пациенты были разделены на две группы: 1 - контрольная, в которой межтеловой спондилодез выполнили по классической методике, в основном за счет прямоугольного би- или три-кортикального костного трансплантата взятого из гребня подвздошной кости; 2 - основная, пациентам которой стабилизирующий спондилодез проводили аутокостным трансплантатом, сформированным по оригинальной методике (патент № 2472461, от 20.01.2013 года).

В основной группе пациентов, где выполняли аутокостный спондилодез по оригинальной методике, количество осложнений со стороны аутотрансплантата в виде его миграции, отсутствии сращения, и воспаления - было достоверно меньше $(p<0,05)$. В случаях отсутствия сращения в оперированном позвоночно-двигательном сегменте, или формирования псевдоартроза с выраженным ортостатическим болевым вертебральным синдромом, в отдаленном периоде выполняли дополнительные хирургические вмешательства - инструментальная стабилизация посредством внеочаговой транспедикулярной фиксации оперированного позвоночно-двигательного сегмента.

Помимо наличия осложнений со стороны аутокостного трансплантата, и отсутствия его сращения со смежными телами позвонков, важным критерием оценки результатов лечения была продолжительность формирования костного блока между аутотрансплатом и смежными позвонками. Из представленных результатов стоит отметить, что изменение формы аутокостного трансплатата по предложенной методике, привело к снижению количества осложнений связанных с миграцией аутотрансплантата и сократило сроки формирования костных блоков между аутотрансплататом и смежными поверхностями тел позвонков $(p<0,05)$. 


\title{
Список литературы.
}

1. Гончаров М.Ю., Левчик Е.Ю. Результаты хирургического лечения неспецифических спондилодисцитов шейного отдела позвоночника // Хирургия позвоночника. 2015. Т. 12. №2. С. 51-55.

2. Проценко А.И., Германов В.Г., Сотиков К.В., Горина Л.Б. Стабилизация шейного отдела позвоночника без использования костной пластики. Костная пластика в современной травматологии и ортопедии. - М. - 2001. - с. 66-67.

3. Cauthen J.C., Kinard R.E., Vogler J.B. et al. Outcome analysis of noninstrumented anterior cervical discectomy and interbody fusion in 348 patients // Spine. - 1998. - Vol.23, №2. - P. 188-192.

4. Kaiser M.G., Haid R.W., Subach B.R., et al. Anterior cervical plating enhances arthrodesis following discectomy and fusion with cortical allograft. // Neurosurgery. - 2002. - 50. - P. 229236.

\section{ОПЫТ ПОЛУЧЕНИЯ ПРЕЦИПИТИРУЮЩИХ СЫВОРОТОК ДЛЯ ИСПОЛЬЗОВАНИЯ В СУДЕБНО-МЕДИЦИНСКОЙ ПРАКТИКЕ}

\author{
Чориев Б.А., Бахриев И.И.
}

\section{Ташкентская медицинская Академия}

Введение. Для постановки иммунологических реакций необходимы специфические преципитирующие сыворотки, которые должны обладать строгой специфичностью и высокой чувствительностью. Большинство серологических и иммунологических методов исследований предусматривают применение иммунных сывороток, которые получают из крови животных, иммунизированных различными антигенами, при этом их активность существенно влияет на результаты исследования. Для получения сывороток необходимо подобрать рациональную схему иммунизации животных $(1,3,4)$. Под этим подразумевают такие факторы, как физико-химическое состояние антигена, дозы, способы, интервалы и кратность введения антигена, общую продолжительность цикла иммунизации, применение адъювантов и иммуномодуляторов.

Поиском и разработкой эф-фективных схем иммунизации животных, для получения гипериммунных сывороток, задавағлись многие ученые, ведущие исследования в этом направлении $(2,5)$.

Цель исследования. Получение специфических иммунных преципитирующих сывороток высокого титра для использования в судебно-медицинской практике. 
Материал и методы исследования. В опытах использованы 48 кроликов обоего пола породы Шиншилла и Великан, массой 3-3,5 кг. Животные содержались в стандартных условиях в соответствие с требованиями методического пособия «Правила и методы работы с лабораторными животными при экспериментальных микробиологических и иммунологических исследованиях».

В качестве антигена для иммунизации кроликов использованы смесь сыворотки крови человека (1-я группа), рогатого скота (2-я группа), птицы (3-я группа), лошади (4-я группа) и 10\% раствор формалина в соотношении 1:1, которая сохранялась в холодильнике при температуре $4-6^{\circ} \mathrm{C}$ в течении 72 часов. В качестве контроля к каждой группе иммунизация кроликов по 2 штуки (всего 8 шт.) производилась сыворотками соответствующих видов и 0,9\% физиологического раствора (5-я группа). Иммунизация кроликов проводилась по схеме предложенной Л.И.Ломовицкой (1977) в модификации Д.Д.Джалалова и Р.А.Хасанова (1997). Антиген вводится в краевую вену уха кролика троекратно, интервалом 1 день в объеме 1 мл/кг веса кролика. Проба крови у иммунизированных животных берётся на 4-й, 7-й и 9-й день после последней инъекции. При наличии преципитинов в сыворотке кроликов титром 1:5000 и 1:10000 производится забор крови пункцией полости сердца и кровопусканием. После иммунизации, если титр преципитирующих сывороток не достигал рабочего титра, то проводилась реиммунизация через две недели после последней иммунизации, однократным введением антигена.

Результаты исследования и обсуждение. Введение сыворотки крови человека, а также животных и 10\% раствора формалина в соотношении 1:1 в объеме 1 мл/кг веса кролика приводила к им-мунному ответу лишь у 70\% иммунизируемых животных после первичной иммунизации, а при введении сыворотки крови птицы процент животных с иммунным ответом достигал 75-78. После реиммунизации положительный результат был достигнут соответственно в 90\% и 95\%. При этом длительность им-мунизации составляла 22 дня, титр полученных иммунных преципитирующих сывороток достигал 1:10000, смертельных случаев у кроликов не наблюдалось.

При такой схеме иммунизации были получены кроличьи гипериммунные сыворотки преципитирующие белок человека, рогатого скота, птицы и лошади с высокой специфической активностью в иммунологических реакциях. При этом иммуностимулирующий эффект при отсутствии токсического воздействия на животное, без возникновения адъювантной болезни, достигался у 90-95\% кроликов.

После первого введения антигенов внешний вид животных из опытных групп ничем не отличался от внешнего вида живот-ных из контрольной группы. После второго введения было замечено небольшое снижение аппетита и подвижности животных. После третьего введения антигенов на месте инъекции, у некоторых животных, отмечали появление гиперемии, учащение сердцебиения. После реиммунизации поведение опытных животных сохранялось таким же вялым по сравнению с контрольными животными, но серьезных изменений в поведении и внешнем виде не наблюдалось. 
После забора крови приступают к определению титра и специфичности полученных сывороток. Преципитирующая сыворотка считается годной для судебно-медицинских исследований, если она имеет титр 1:10000, т.е. когда при добавлении ее к гомологичной нормальной сыворотке, разведенной в 10000 раз, осадок выпадает в пределах 10 минут и она не дает осадков нормальными изосыворотками других видов, разведенными в 1000 раз в пределах одного часа.

Результаты показали, что титр антител в первой группе в 9 случаях соответствовал 1:5000 и в 7 случаях 1:10000. Во второй группе в 9 случаях соответствовал 1:5000 и в 8 случаях 1:10000, в третьей группе в 10 случаях соответствовал 1:5000 и в 9 случаях 1:10000, в четвертой группе в 9 случаях соответствовал 1:5000 и в 8 случаях 1:10000.

Установлено, что все полученные преципитирующие сыворотки были специфичными, т.е. в разведении 1:1000 в течение 1-го часа реакции преципитации, кроме соответствующего вида, с другими антигенами не происходило.

Благодаря применению иммуностимулирующего действия 10\% формалина значительно сокращены длительность процесса иммунизации (22 дня) и получение высокоспецифической сыворотки, при этом повышен выход целевого продукта за счет увеличения антителообразования у животных с одновременным уменьшением трудозатрат. Также нужно отметить, что однократной реиммунизацией удалось увеличить процент положительных результатов в 90-95\% случаях.

Таким образом, по результатам исследования разработаны эффективные схемы иммунизации для получения гетероиммунных сывороток, основанные на оптимальной комбинации белковых антигенов в комплексе с 10\% раствором формалина, обеспечивающим высокий иммунный ответ у 90-95\% животных, значительное сокращение сроков иммунизации, материальных и трудозатрат. Полученные гетероиммуннные сыворотки являются высокоспецифическими и считаются пригодными для применения в судебно-медицинской практике.

\section{Список литературы.}

1. Гамалея Н.Б., Берзина А.Г. Вакцины от наркотиков - новое перспективное направление профилактики злоупотребления ПАВ. //«Наркология». Биомедицина. 2011. - №2. - С. 7083.

2. Джалалов Д.Д., Айдаркулов А.Ш. Определение видовой специфичности белков крови методом радиальном иммунодиффузии в геле. //Судебно-медицинская экспертиза. 1982. - №2. - С. 36-37.

3. Сидиров В.Л., Ягмуров О.Д. Опыт использования иммуноферментного анализа при установлении видовой принадлежности крови на вещественных доказательствах. Ученые записки СПбГМУ им. Акад. И.П. Павлова. 2013. Том ХХ. №3. - С. 61-62. 
4. Aguilar J.C., Rodriguez E.G. Vaccine adjuvants revisited //Vaccine. - 2007. - № 25. - P. 37523762.

5. Byars N.E., Allison A.C. Immunologic adjuvants: general properties, advantages, and limitations. //Laboratory Methods in Immunology. - 1990. - P. 39-51.

\title{
ОСОБЕННОСТИ ЭПИДЕМИОЛОГИИ ЗЛОКАЧЕСТВЕННЫХ НОВООБРАЗОВАНИЙ
}

\author{
Шукелайть С.П. (1), Семынина Н.М. (2), Дрошнева Т.Н. (2), Панина \\ 0.A. (2), Матасова Ю.А. (2)
}

ФБУз «Центр гигиены и эпидемиологии в Воронежской области» (1)

ФГБОУ ВО «Воронежский государственный медицинский университет имени Н.Н.Бурденко» Минздрава России (2)

Последнее десятилетие характеризуется ухудшением демографических показателей, нарастающим негативным влиянием среды обитания на население РФ [1,2]. Факторы антропогенной природы приводят к изменениям иммунной системы [3]. Злокачественные новообразования являются своеобразным индикатором, отражающим реакцию на вредное воздействие окружающей среды. Согласно статистическим данным, Воронежская область входит в число неблагоприятных регионов страны по заболеваемости злокачественными новообразованиями. Экологических подход к профилактике является одним из наиболее действенных путей повышения оперативности управления заболеваемостью [4,5]. Установлена географическая обусловленность территорий повышенного онкологического риска для населения. Так, заболеваемость раком лёгкого и желудка достоверно выше в районах, где снижается мощность верхнего слоя четвертичных (современных) пород и ухудшается степень чистоты водоносных горизонтов, из которых вода используется для питьевых и хозяйственных нужд, а естественная способность накопления породами радиоактивных веществ наиболее высокая. Кроме того, заболеваемость, как правило, выше среднеобластного уровня в районах с максимальной высотностью (свыше 160 метров над уровнем моря), где преобладают эродированные водоразделы с дисбалансом микроэлементов в почве (недостаток молибдена и избыток бария, йода, титана), с развитием карстовых процессов в меловых подстилающих породах. Настораживающие прогнозные данные получены по некоторым факторам социально-экономической сферы. Заболеваемость раком кожи, молочной железы, прямой кишки, шейки матки имеет положительную корреляцию средней степени с объёмами атмосферных выбросов окиси углерода, углеводородов по районам области, причём наиболее существенна эта закономерность в отношении рака 
молочной железы, более характерного для городских районов с наиболее высоким уровнем загрязнения атмосферы. Этот факт противоречит общепринятым представлениям о взаимосвязи заболеваемости раком молочной железы с внешними факторами и требует уточнения. Чаще, чем у других контингентов области, новообразования отмечаются у работников агропромышленного комплекса в возрасте старше 50 лет. Негативная роль контактов сельского населения с химическими средствами обработки почв и защиты растений проявляется при анализе масштабов пестицидного загрязнения земель. Подсчитано, что увеличение на 10 процентов размера площадей, подвергающихся ежегодному авиахимопылению с целью уничтожения вредителей подсолнечника, вызовет ответное увеличение заболеваемости злокачественными новообразованиями и смертности от них соответственно на 3.1 и 3.5 случаев на 100 тысяч населения в год. Причём, такая зависимость начинает проявляться при обработке 3-х и более процентов площади районов. Наблюдается общий рост онкологических заболеваний в районах, где в течение ряда предшествующих лет регистрировался наиболее высокий процент неудовлетворительных проб мясо-молочной продукции по санитарно-химическим показателям (при увеличении на $10 \%$ количества неудовлетворительных проб пищевых продуктов ожидается рост заболеваемости раком среди лиц в возрасте 50 - 70 лет на 7.8 случаев на 100 тысяч населения этого возраста в год). Рак желудка и щитовидной железы достоверно чаще выявляется в районах максимальной плотности высоковольтных линий электропередач напряжением от 35 до 500 кВ, с высокой густотой общей автодорожной сети. Оценка онкоэкологической ситуации в районах области по указанным параметрам позволяет провести ранжирование районов по уровню онкоэкологического благополучия. Наиболее неблагоприятная онкоэкологическая ситуация наблюдается в Семилукском районе, где основными экологическими факторами риска являются: большие объемы атмосферных выбросов, радиационное загрязнение, избыток бария в почве, максимальная густота дорог и плотность электроподстанций 35 кВ, загрязнённые подземные водоносные горизонты; Нижнедевицкий и Хохольский районы, в которых в качестве основных экологических факторах риска выделяют: радиационное загрязнение (более 47\% площади), интенсивное авиахимопыление, избыток бария в почве, низкая комфортность природных условий. Наименьший уровень онкогенных факторов риска экологического характера выявлен в Верхнемамонском, Кантемировском, Новохопёрском, Павловском и Поворинском районных. Эти районы характеризуются высокой комфортность природных условий, умеренными химизацией и сельскохозяйственным освоением.

\section{Список литературы.}

1. Панина О.А. Роль экологического компонента профессиональной компетенции у студентов-медиков и пути его формирования // В сборнике: Медико-биологические и педагогические основы адаптации, спортивной деятельности и здорового образа жизни сборник научных статей IV Всероссийской заочной научно-практической конференции с международным участием. под редакцией Г.В. Бугаева, И.Е. Поповой. 2015: 568-573. 
2. Мамчик Н.П., Панина О.А. Видиопрактикум как инновационный метод обучения студентов в медицинском вузе. Научно-медицинский вестник Центрального Черноземья.2008. № 31:55-56.

3. Погорелова Е.И., Почивалов А.В., Панина О.А. Особенности иммунокоррегирующей терапии в детском возрасте. В сборнике: пути и формы совершенствования фармацевтического образования. актуальные вопросы разработки и исследования новых лекарственных средств Материалы 7-й Международной научно-методической конференции "Фармобразование-2018". Воронежский государственный университет; Под общей редакцией А.С. Беленовой, А.А. Гудковой. 2018: 554-557.

4. Панина О.А., Солунина М.А., Краснопольская А.М., Маховая Л.В., Исаева В.А. Роль инновационных образовательных технологий в обучении студентов медицинских вузов // Медицинское образование и профессиональное развитие. 2012. № 3 (9): 96-97.

5. Шевцов М.В., Шелякина П.А., Панина О.А., Шестоперстова Л.А., Хачикян Н.С., Хачикян А.С. Экологический компонент профессиональной компетенции, как фактор повышения качества обучения студентов в медицинском вузе. В сборнике: Гигиенические и экологические аспекты профилактики заболеваемости на региональном уровне Материалы III Межвузовской научно-практической конференции. 2018: 56-61.

\section{ПРОГНОЗИРОВАНИЕ СКЛОННОСТИ К СПАЕЧНОМУ ПРОЦЕССУ У ДЕТЕЙ ПОСЛЕ ХИРУРГИЧЕСКИХ ВМЕШАТЕЛЬСТВ}

Бердиев Э.А., Турабаева З.К.

\section{Термезский филиал Ташкентской медицинской академии}

Актуальность. Острая спаечная кишечная непроходимость (СКН) у детей - одно из самых распространенных в абдоминальной хирургии тяжелых заболеваний, требующих экстренного оперативного вмешательства. Частота патологии, по данным разных авторов, колеблется от 1,1 до 6\% у детей, перенесших оперативные вмешательства на органах брюшной полости. Актуальность и нерешённость вопросов СНК у детей обусловлены высокой частотой встречаемости патологии, склонностью к рецидивирующему течению (до 7-10\%), высоким уровнем осложнений и летальности (до 31,5-40\%). По имеющимся литературным данным, спайкообразование с непроходимостью наиболее часто в детском возрасте развивается после аппендэктомий (до 37,5\%), операций по устранению обтурационной непроходимости (до 22,9\%), колопроктологических операций (до 10\%) [25]. Любое оперативное вмешательство на органах брюшной полости сопровождается развитием спаечного процесса той или иной степени выраженности. 
Целью исследования явилось изучение индивидуальной склонности к спаечному процессу в брюшной полости у детей, которым выполнены оперативные вмешательства.

Материал и методы исследования. Нами проанализированы истории болезни 53 больных в возрасте от 5 до 17 лет, оперированных по поводу острой хирургической патологии брюшной полости с 2010 -по 2018 гг., которая осложнилась острой спаечной кишечной непроходимостью. Из них мальчиков было -34, девочек-19. Ранее в 42 случаях была выполнена аппендэктомия, по поводу перфорации язвы 12-перстной кишки - в 5 случаях, резекция желудка - в 3, и по поводу травмы органов брюшной полости были оперированы 3 детей. Известно, что одним из ключевых моментов в патогенезе формирования послеоперационных спаек является нарушение в системе тканевого фибринолиза $[1,2,3,6]$, поэтому нами было решено изучить состояние фибринолиза и концентрации фибриногена у этих детей, до операции, во время операции, и в послеоперационном периоде в течение 5 суток. У всех детей через 2 часа была взята венозная кровь для исследования концентрации фибриногена и фибринолитической активности крови.

Результаты исследования и их обсуждение. У 29 (54,7\%) больных до операции было выявлено повышение концентрации фибриногена, который составил 412 18,4 мг/\%, (в норме в среднем 338 26 мг\%). У 24 (45,2\%) выявлено резкое угнетение

фибринолитической активности крови, которая колебалась от 96 до 158 мг\%, в среднем составила 136 7,6 мг\%. Эти показатели свидетельствовали о том, что на фоне резкого угнетения фибринолитической активности крови создаются оптимальные условия для превращения фибриногена в фибрин, а фибрин переходит в коллаген, что является началом спаечного процесса. Полученные данные исследований свидетельствовали, о том, что больные, у которых резко нарастает концентрация фибриногена и угнетается фибринолиз, являются склонными к спаечному процессу. Естественно эти больные требуют соответствующей коррекции фибринолитической активности для раннего предотвращения спаек. С этой целью в конце операции всем больным в брюшную полость вводили фибринолитическую смесь, состоящую из гепарина 10000 ЕД+ фибринолизин 20000 ЕД+ гидрокортизон 125мг+ гентамицин 80мг+раствор и новокаина 0,25\%-200. Больные, которым был оставлен, микроирригатор в брюшной полости эту же смесь водили через каждые 6-8 часов. Через 6 часов после вливания вновь исследовали венозную кровь. При этом было отмечено снижение, концентрации фибриногена по

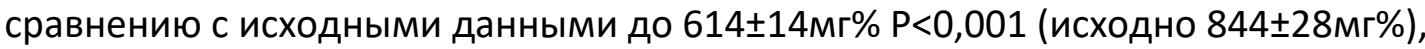

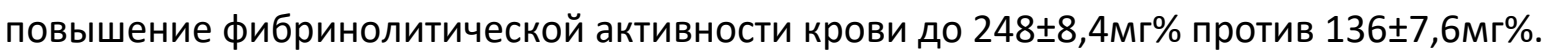
Известно, что при высокой концентрации фибриногена, естественно фибринолиз остается несколько угнетенным. Учитывая выше изложенное, мы продолжали внутрибрюшинное введение фибринолитической смеси 2-раза в день. В конце вторых и начале третьих суток было отмечено постепенное снижение концентрации фибриногена, но показатели были различны у всех больных. На третьи сутки, после операции у 38 (71,7\%) больных было выявлено снижение концентрации фибриногена в среднем до 402‡12 мг\%, а у 15 (28,3\%) детей фибриноген оставался высоким до 486 16 мг\%. Наряду с этим отмечалось

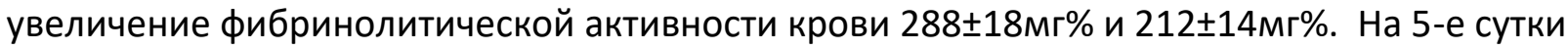


после операции все больные были активными, перистальтика кишечника хорошо выслушивалась и пассаж кишечника был восстановлен. Повторно взятые анализы

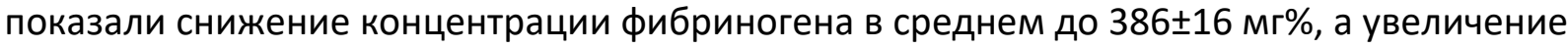
фибринолитической активности в среднем до 302ะ6,0мг\%. Эти показатели особо не отличались от нормальных величин.

Выводы. Таким образом, можно сделать заключение, что концентрация фибриногена и фибринолитическая активность крови имеют ключевое значение в патогенезе спаечного процесса. Во время оперативных вмешательств можно выявлять больных, имеющих склонность к спайкообразованию в зависимости от показателей концентрации фибриногена и фибринолитической активности крови. Склонными к спаечному процессу можно считать тех больных, у которых резко повышается концентрация фибриногена более 1 млн. мг\% и снижение фибринолитической активности до 60-80мг\%. Для ранней профилактики с момента оперативного вмешательства в комплексе лечения необходимо внутрибрюшное введение фибринолитической смеси через дренаж под контролем концентрации фибриногена и фибринолитической активности венозной крови.

\section{Список литературы.}

1. Аршинов, А. Исследование системы гемостаза в клинической практике / А. Аршинов // Журнал Врач. - 2000.- №9.- С. 30-31.

2. Гуляев, В. А. Нарушение гемостаза и его коррекция при операциях на печени / В.А. Гуляев // Анналы хирургической гепатологии. - 2005. - №1. - С. 122-130.

3. Минаев, С. В. Течение спаечного процесса брюшной полости в детском возрасте / С.В. Минаев // Медицинский вестник Северного Кавказа. - 2009. - Т. 13. №1. - С. 17-20.

4. Минаев, С. В. Полиферментная терапия в профилактике спаечного процесса в брюшной полости у детей / С.В. Минаев, Т.К. Немилова, Г.Ю. Кнорринг // Вестник хирургии. - 2006. Том 165, №1. -С. 49-54.

5. Эндовидеохирургические технологии в диагностике и лечении острой спаечной кишечной непроходимости / В.В. Стрижелецкий, В.М. Седов, С.А. Макаров // Мат-лы XI съезда хирургов Российской Федерации: тез. докл. XI съезда хирургов Российской Федерации - Волгоград, 2011. - С. 325.

6. Липатов В.А. К вопросу патофизиологии послеоперационного спаечного процесса брюшной полости // Innova. - 2017. - №8 (3). - С. 13-17. 


\section{ПРОФИЛАКТИКА ГНОЙО-СЕПТИЧЕСКИХ ОСЛОЖНЕНИЙ В ПОСЛЕРОДОВОМ ПЕРИОДЕ \\ Муминова H.X.}

\section{Ташкентский институт усовершенствование врачей}

В современном акушерстве дискутабельным остается вопрос о проведении рутинной антибиотикопрофилактики после операции кесарева сечения для снижения инфекционных послеоперационных осложнений.

Анализ литературных данных показал, что в акушерстве частота септических заболеваний (С3)возрастает в 8-10 раз при оперативных родах, в частности при кесарево сечение $(1,4,7)$.

Своевременное комплексное ведение таких осложнений может снизить ожидаемые С3, такие как эндометриты, перитониты и тромбофлебиты до 57\%. $(5,6)$.

Целью исследования явился анализ частоты инфекционных осложнений после проведения антибиотикопрофилактики при различных оперативных вмешательствах, в том числе и кесарево сечение.

Проведено ретроспективное исследование течения беременности, родов и послеродового периода у50 женщин, родоразрешенных путем операции кесарева сечения, которым интраоперационно п была введена профилактическая доза антибиотиков.Следует отметить, что у всех родильниц данной группы не было отмечено развития раневой инфекции, эндометрита либо тяжелых гнойно-септических осложнений. Большинство пациенток (38 \%) входили ввозрастную группу 31-35 лет, 34 \% - 26-30лет, 18 \% женщин были старше 36 лет и $10 \%$ - были в возрасте до 25 лет.

Соотношениепервородящих к повторнородящим составило 2:3,при этом повторное КС было выполнено в 44 \% случаев. Плановое кесарево сечение было проведено в 24 случаях (48 \%), экстренное - в 52 \%.Настоящая беременность наступила самопроизвольно у $90 \%$ женщин, в результате стимуляции овуляции клостильбегитом и заместительной гормональной терапией - у $10 \%$. Анализ ИМт ( индекс массы тела), что 64 \% женщин имели нормальный индекс массы тела, 20 \% -ожирение 1 степени,, у 16 \% отмечено ожирение 2степени.

В структуре показаний к плановому кесареву сечению превалировали: рубец на матке $20 \%$, анатомический узкий таз - $16 \%$, тазовое предлежание плода $-12 \%$, другие - 10 \% ( рубцовая деформация шейки матки после предыдущих родов, двукратное обвитие пуповиной вокруг шеи плода, разрывы шейки матки 3-степени). Показанием к экстренной операции кесарева сечения являлись: начало родовой деятельности,либо преждевременное излитие околоплодных водпри рубце на матке - $22 \%$, прогрессирующая илиострая гипоксия плода - 12 \%, сочетанные показания - в $16 \%$ случаев. 
Также нами было выявлено, что большинство женщин имело системной и местной инфекции иперед операцией (72\%), но не в стадии обострение. Только у 12 \% женщин имело место обострение герпес-вирусной инфекции во время беременности, у 56\%вагинальные инфекции(кандидозный вагинит, бактериальный вагиноз и др). Во всех случаях была проведена адекватная санациягенитального тракта. При анализе гинекологического анамнеза у 10 \% женщин имели место 2 и более медицинских аборта, у $12 \%$ - привычное невынашивание, у $18 \%$ - бесплодие, у $24 \%$ - оперативные вмешательства лапароскопическим доступом (миомэктомия у 4 женщин, резекция яичников у2, удаление придатков у2).Средняя длительность пребывания пациенток в стационаре дородоразрешения составила 4,2дня.Учитывая, что длительное пребывание женщины в стационаре является одним из важных факторов риска развития послеоперационной инфекционной заболеваемости, беременные были госпитализированы в стационар ближе к сроку родов (при отсутствие экстренных показаний к госпитализации или возникшими осложнениями течение данной беременности). У32\% женщин пребывание в стационаре дородоразрешения составило менее 24часов.

Анализ оперативного вмешательства показал, что средняя длительность операции составила30,1+2,4мин., объем кровопотери 550,5+44,7мл.

Расширение оперативного вмешательства былоуЗпациенток, производилась миомэктомия, при этомданные операции были запланированы. Длительность операции более 60минут отмечалась только в2случаях. Величина кровопотери-800мл была у 1 пациентки, данное кесарево сечение являлось повторным, плацента располагалась по передней стенке в области разреза на матке, имело место варикозное расширение вен нижнего маточного сегмента.

С целью профилактики ГСЗ в послеоперационном периоде из 50 больных 27 назначено АБ профилактика в течение 3 суток (цефалоспорины в терапевтических дозах). Если у больных отягощённый гинекологический и акушерский анамнез, обострение ИППП, обострение соматической патологии воспалительного характера мы отдавали предпочтение назначению цефалоспоринов 2-4 генерации, например Жиосеф (цефепим) (Shayanafarm, Индия) по 0,5-1г в сутки в/,м или в,/в.

Назначение АБ высокой генерации (Зили 4-поколения) в послеоперационном периоде было обосновано наличием хронической внутриматочной инфекции, состоянием органов(матки и придатков) и тканей интраоперационно. Также учитывалось характер околоплодных вод (зеленые, с запахом), расширение оперативного вмешательства при КС. Остальным 23 женщинам ограничились интраоперационным введением АБ, без продолжение в послеоперационном периоде его.

Группа женщин, где получали АБ течение послеоперационного периода протекала без эпизодов инфекционного возбуждение, сокращение матки соответствовало дню перенесенной операции, лохии имели обычную окраску и запах, физиологические отправление были в норме .Общее состояние пациенток данной группы оценивали на 
отлично или хорошо, спокойно кормили грудью, никакие дискомфортные явления не диагностированы.

УзИ критерии матки и придатков совпадало с данными литературы (2), где, положительная ультразвуковая динамика ко 5-му дню лечения наблюдалась у 66,7\% пациентов, получавших продленный курс антибактериальной терапии в послеродовом периоде, и лишь у 33,3\% больных без АБ терапии.

Критериями улучшение УзИ показателей явились: уменьшение передне-заднего размера матки, уменьшение гипоэхогенности матки, сужение полости матки (в случаях ее расширение из-за анэхогенного содержимого) и исчезновение гиперэхогенных образований в области лигатур с уменьшением скопления газа, линейных гиперэхогенных образований, свидетельствующие об устранение фибриновых наложений и с резким уменьшением или исчезновением локальной эхогенности в области швов.

Также быстрее регрессировали и острофазовые показатели крови: лейкоцитоз снизился в среднем до 7,5, лиИ до 1-1,5, концентрация ПкТ $\leq 0,5$.

В группе больных не получавших АБ у7родильниц в послеоперационном периоде отмечались гнойно-септические осложнения, которые потребовали назначения антибиотиков не менее двух видов , причем широкого спектра действие: в5случаях послеродовый период осложнился нарушением сократительной активности матки (субинволюция матки), при этом производилась вакуум-аспирация содержимого полости матки с одновременной антибактериальной терапией.

Таким образом, проведенный анализ оперативных родов показал, что антибиотикопрофилактика при кесарево сечение без манифестных форм инфекции способствует снижение гнойно-септических осложнений. Так как после перенесенной операционной агрессии для организма матери, защитно-приспособительные звенья претерпевают серьезные изменения, в сторону резкой иммуносупрессии, тем самым усугубляют процессы адаптации и восстановления.

Поэтому при правильной оценке инфекционного риска перед оперативным родоразрешением с обоснованным назначением адекватных доз антибиотиков: где отдаются предпочтение цефалоспоринам высокой генрации с продолжением в послеоперационном периоде в течение не менее 3-х суток с одновременной санацией генитальной инфекции при ИППП, способствует подавлению инфекционного агента с резким уменьшением частоты септических осложнений в послеродовом периоде. $(3,5,7,8)$.

\section{Список литературы.}

1. Абрамченко В.В. Гнойно-септическая инфекция в акушерстве и гинекологии.- СПб.: Спецлит, 2005.- С.459 
2. Белоцерковцева Н.Д., Мазуркевич В.В. Клиническое значение трансвагинальной эхографии и гистероскопии в диагностике послеродового эндометрита// Акушерство и гинекология.- 1996.- №4.- С.37-40.

3 Джураева Д.Л.Роль преморбидного фона вгенезе репродуктивных нарушений у девочек-подростков Новости дерматовенерологии и репродуктивного злоровья № 3-4(І) 2017 г. С.43-44

4.. Иванян А.И., Крюковский С.Б. Профилактика и лечение послеродовых гнойносептических заболеваний.- Смоленск, 2000.- С.47

5. Горожанкина К.В., Пашина И.В., Пономарёва Н.А. Динамика и территориальные различия заболеваемости осложнениями беременности, родов и послеродового периода в регионах России в 2010 - 2017 годах // Innova. - 2017. - №8 (3). - С. 21-24.

6. Орджоникидзе Н.В., Федорова Т.А.Эндометрит и раневая инфекция у родильниц. Проблемы и пути их решения// Акушерство и гинекология.- 2004.- №5.- С.15-7.

7. Левашова Н.И., Мареева Л.С. Проблемы кесарева сечения в современном акушерстве// Акушерство и гинекология.- 2004.- №2.- с.23

8. Abouzahr C, Aaahman E, Guidotti R. Puerperal sepsis and other puerperal infections. InHealth dimensions of sex and reproduction: the global burden of sexually transmitted diseases, maternal conditions, perinatal disorders, and congenital anomalies, eds.

CJLMurrayandADLopezWHO 1998

\section{РОЛЬ И ПРИМЕНЕНИЕ СОВРЕМЕННОЙ УЛЬТРАЗВУКОВОЙ ДИАГНОСТИКИ УЗЛОВЫХ ОБРАЗОВАНИЙ ЩИТОВИДНОЙ ЖЕЛЕЗЫ Мамадалиева Я.М., Хушназаров X. X.}

\section{Ташкентский институт усовершенствования врачей}

Актуальность. Заболевания щитовидной железы (ЩЖ) являются одним из важнейших проблем современности и в настоящее время занимают лидирующее положение среди эндокринологических проблем. По сводным данным частота встречаемости узловых образований щЖ за последние 30 лет увеличилась с 4-9\% до 5-22\%, а за последние 10 лет рак ЩЖ участился в 2 раза, являясь причиной смерти 1\% онкологических больных [4]. При этом. среди всех доброкачественных и злокачественных новообразований головы и шеи на долю патологии щитовидной железы приходится от 1,5 до 3,5\%. В связи с этим, на сегодняшний день актуальны вопросы ранней и дифференциальной диагностики узловых образований щитовидной железы. Таким образом вопросы ранней и дифференциальной 
диагностики всех узловых образований щитовидной железы остаются актуальными [1,3]. Особое место на современном этапе занимает высокая информативность эхографии, что позволяет применять ультразвуковую визуализацию для диагностики заболеваний на ранних и даже доклинических стадиий заболевания $[4,5,7]$. К сожалению даже при использовании новейших ультразвуковых технологий при попытках классифицировать эхографическую семиотику и систематизировать данные при дифференцировке ультразвкуовых признаков рака щитовидной железы и морфологических форм рака до настоящего времени вопрос считается открытым, а проблема актуальной [1,5]. Внедрение инновационных технологий открывают новые перспективы уточняющие диагностику узловых образований $[2,3,6]$. Однако, роль и место высоких технологий эхографии изучены недостаточно.

Цель исследования. Улучшение дифференциальной и уточняющей диагностики рака щитовидной железы путем применения современного ультразвукового исследования

Материалы и методы. Под наблюдением находились 120 пациентов, направленных на УзИ для уточнения характера узловых образований в щитовидной железе. Возраст пациентов варьировал от 20 до 68лет. Среди обследованных пациентов мужчины и женщины составили 42 (35\%) и 78 (65\%) соответственно. УзИ выполняли на современных ультразвуковых аппаратах «MINDRAY ДС-70» (Китай), Logiq S8 XD clear GE Healthcare (США), HI VISION Preirus (Hitachi Medical Corporation, Япония) и Samsung-Medison WS 80 AC ELITE (Южная Корея) с диапазоном частот линейного датчика 7,5-13 МГц, обеспечивающих визуализацию в реальном режиме серой шкалы, получение характеристик допплеровских исследований, эластографии. Ультразвуковое исследование выполняли по стандартной методике с проведением серошкального исследования, допплерографии (ЦДК, ЭДК, спектрального допплера), а также режима эластографии (компрессионной и сдвиговой волны) с помощью которого оценивалась жесткость очаговых образований щитовидной железы.

Пациенты были разделены на 4 группы:

В 1-ю группу (n=30) вошли пациенты, при обследовании которых были обнаружены очаговые образования щЖ диаметром до 10 мм.

2-ю группу (n=30) составили пациенты, при обследовании которых были обнаружены очаговые образования щж диаметром более 10 мм.

3-ю группу ( $n=30)$ вошли пациенты, которым было проведено оперативное вмешательство по поводу узловых образований щж.

4-ю группу ( $n=30)$ составили больные, которые получили предоперационную химиолучевую терапию по поводу различных форм РщЖ.

Результаты исследования и их обсуждение. У 62 (52 \%) обследованных пациентов были выявлены единичные, у 58 (48\%) множественные узловые образования щитовидной железы. У 30 (25\%) пациентов, с выявленными очаговыми изменениями, 
патоморфологически подтверждены:папиллярный рак у 23 (19,1 \%), фолликулярный рак у $5(4,2 \%)$, медуллярный рак у $2(1,6 \%)$,первичный очаг с поражением региональных лимфатических узлов у 1 (0,1\%) больного (рисунок1,2,3,4). Из 120 пациентов изменение размера, в сторону увеличения железы были у 82 (68,3\%), неровность контуров наблюдалось у 43 (35,8\%) пациентов, неравномерная эхогенность - у 57 (47,5\%), ободок «хало» - у 81 (67,5\%), увеличение объема щитовидной железы у 94 (78,3\%), кальцинаты у 41 (34,2\%), гиперваскуляризация у 103 (86\%) пациентов. Показатели эластичности ткани щитовидной железы были выше у $104(86,6 \%)$ пациентов. Среди них диапазон эластичности доброкачественных образований колебался от 25 до 68 кПа, а злокачественных образований от 70 до 169 кПа (норма 6,7-19,8 кПа). Характерными ультразвуковыми признаками наиболее часто встречаемого папиллярного рака $(\mathrm{n}=23)$ щЖ являлись: неправильная форма, неровные границы, нечеткие контуры, пониженная эхогенность, неоднородность эхоструктуры образования; сохранность капсулы щж; гиперваскулярность узла, асимметричность, хаотичность, дезорганизованность сосудистого рисунка в его структуре, патологическая трансформация сосудов. Фолликулярный рак ( $(\mathrm{=}=5)$ щЖ чаще, чем остальные формы, характеризовался гиперэхогенными и средней эхогенности узлами, структура которых также была чаще неоднородной; реже, чем при других формах, встречались кальцинаты, чаще - ободок отграничения. Также чаще встречались аваскулярная и гиповаскулярная формы. Медуллярный рак (n= 2) ЩЖ в отличие от других форм часто определялся как овальной формы гипоэхогенное образование, чаще по сравнению с другими формами эхоструктура узлов была однородной. Васкуляризация всегда была высокая.

Выводы. Таким образом, применения современном ультразвуковом исследовании очаговых образований щитовидной железы наиболее информативным ультразвуковым критерием явилось неровность контуров, увеличение объема, наличие кальцинатов, гиперваскуляризация и снижение эластичности пораженной ткани. Современной ультразвуковое исследование, включающее В-режим, ЦДК, ЭДК, спектрального допплер и эластографию, является высокоинформативным методом диагностики в раннем выявлении рака щитовидной железы. Современное ультразвуковое исследование с применением эластографии повышает чувствительность УзИ в диагностике рака щитовидной железы до - 93,2%, а специфичность до-91,6\%.

\section{Список литературы.}

1. Аденома - узловая форма заболевания щитовидной железы. /Островский К.А., Шмейс С.Н., Островский А.Г., и др.//Тенденции развития науки и образования. 2018. Т. 37. № -5. C. 39-44.

2. Диагностика злокачественных опухолей щитовидной железы / Федотов Ю.Н. и др.. // Фомина Н.Ю., Санкт-Петербургского университета. Серия 11.-Медицина.-Вып. 3.-2017.-С. 211-215. 
3. Митьков В.В., Митькова М.Д. Ультразвуковая эластография сдвиговой волной.//Уьтразвуковая и функциональна диагностика. - 2015. - № 2. - С. 94-108.

4. Матвеев Г.А., Копина М.Н. Ультразвуковое исследование щитовидной железы как скрининговый метод диагностики ее изменений.//Ученые записки Новгородского государственного университета. 2015. № 2 (2). С. 16.

5. Осипов Л.В. Технологии эластографии в ультразвуковой диагностике. Обзор //Диагностическая радиология и онкотерапия.2013 № 3-4. С.5-23.

6. Паршин В.С., Тарасова Г.П., Павлинова Е.С. Эластография сдвиговой волны в дифференциальной диагностике доброкачественной и злокачественной природы узловых образований щитовидной железы // Радиация и риск. - 2014. - Т. 23, № 2. - С. 72-84.

7. Analysis of post operative complications following total thyroidectomy / Atiq100. M.T.et al. // Mymensingh Med. J. 2011 - Vol. 20 (2). - P. 238-244.

\section{СРАВНЕНИЕ КАЧЕСТВА ЖИЗНИ ПАЦИЕНТОВ ПОСЛЕ ГЕМОРРОИДЭКТОМИИ С ИСПОЛЬЗОВАНИЕМ КЛАССИЧЕСКОГО МЕТОДА МИЛЛИГАНА-МОРГАНА И ГЕМОРРОИДЭКТОМИИ AППАРАTOM «LIGASURE»}

Гавриков А.К., Новиков Ф.В., Гаврикова Д.И., Старкова О.А. Курский государственный медицинский университет

В структуре колопроктологических заболеваний хронический геморрой занимает первое место и составляет порядка 40\% от их общего числа. Для пациентов, имеющих III-IV стадию заболевания единственным способом лечения является хирургический удаление всех геморроидальных узлов.

Методика операции по E. Milligan и G. Morgan, признанная классической, уже долгое время используется колопроктологами, однако ее травматичность приводит как к множеству осложнений в интраоперационном и постоперационном периодах, так и к ухудшению качества жизни пациентов, подвергшихся данному хирургическому вмешательству. Одной из альтернатив традиционной хирургической методики является электрокоагулирование с использованием аппарата «LigaSure» компании «Valleylab». Данная коммерческая организация запатентовала технологию Smart technology, позволяющую при наложении инструмента на ткань оказывать оптимальное компрессионное воздействие, так как при работе генератора "LigaSure» происходит измерение начального диагностического импульса и осуществляется им автоматический 
выбор необходимых параметров электрической энергии, воздействующей на ткани, что позволяет сократить продолжительность операции и количество послеоперационных осложнений.

Цель исследования - сравнение качества жизни пациентов, перенесших геморроидэктомию по методу E. Milligan и G. Morgan и ее модернизации с использованием аппарата «LigaSure».

Материалы и методы исследования. Клинический материал составил 90 пациентов с хроническим геморроем III - IV ст. Первую группу составили 50 пациентов, им проведены операции с использованием генератора «LigaSure», во второй группе - 40 пациентов, которые были прооперированы по Миллигану-Моргану. В выборочной совокупности мужчин было 47 (61,7\%), женщин 43 (38,3\%). Возраст колебался от 32 до 60 лет (в среднем $46,5 \pm 10,5$ лет). Для оценки качества жизни нами использовался опросник SF-36 (The Short Form-36). Полученные результаты были обработаны с применением методик математической статистики. Статистическая обработка результатов нами была проведена на персональном компьютере с использованием пакета прикладных программ Statsoft Statistica 6.0 (ППП Statistica), непараметрическими методами (метод Спирмена) с учетом имеющейся выборки. Рассчитывали средние арифметические значения и стандартное отклонение ( \pm \pm ). Значимыми считали различия при $\mathrm{p}<0,05$.

Результаты и их обсуждение. У пациентов 1 группы, которым были проведены операции с использованием генератора «LigaSure», были достоверно выше показатели физического и психического здоровья, по сравнению с другими группами. Оценив физический компонент в исследуемых группах, мы получили следующие результаты: в 1 группе физический компонент здоровья составил 75,7\%, во 2 группе $-52,8 \%(p<0,05)$. Психологический компонент в 1 группе составил - 70,6\%, во 2 группе 60,7\% (p<0,05). Данные результаты мы связываем с более щадящим воздействием генератора на оперируемую ткань, так как напряжение проводит энергию через ткань очень быстро, что позволяет коллагену в стенках сосудов и соединительной ткани быстро и равномерно плавиться, превращаясь в гомогенную субстанцию, образуя некоторое подобие пластиковой клипсы на сосуде. Это сокращает время лигирования, обеспечивает постоянный и воспроизводимый эффект. Несомненно, что оптимальная компрессия, оказываемая инструментом, обеспечивает плотность формируемой структуры. Также немаловажен тот факт, что ток на выходе генератора пульсирующий, что позволяет ткани охлаждаться между подачей энергии. Это поддерживает низкий уровень импеданса и позволяет большему количеству энергии пройти через ткань в короткое время, что обеспечивает максимальную эффективность генератора и уменьшает распространение тепла.

Заключение. Как мы видим из результатов исследования, физический компонент в группе пациентов, которым были проведены операции с использованием генератора «LigaSure», в 1,4 раза выше, чем в группе больных, которые были прооперированы по МиллигануМоргану. Психологический компонент в 1 группе в 1,2 выше, чем во 2 группе, соответственно. Это позволяет нам утверждать, что щадящие хирургические методики, 
используемые при лечении хронического геморроя, позволяют не только излечить пациента от данного страдания, но и улучшить качество его жизни.

\section{Список литературы.}

1. Тимербулатов, В.М. Электролигирование в лечении хронического геморроя / В.М. Тимербулатов, Д.И. Мехдиев, Р.Р. Фаязов, Р.Р. Ахмеров // Колопроктология. - 2015. №S1(51). - С. 47-47a.

2. Бичурин, Н.Р. Геморроидэктомия - оценка современных возможностей хирургического лечения / Н.P. Бичурин // Колопроктология. - 2016. - №S1(55). - С. 15-16.

3. Бичурин, Н.Р. Геморроидэктомия с использованием современных электрохирургических инструментов / Н.Р. Бичурин, А.В. Бичурина, А.А. Бичурина // Колопроктология. - 2019. - №S3(69). - С. 19.

4. Геморроидэктомия при хроническом геморрое: выбор оптимального способа / С.В. Аникин, В.В. Яновой, А.А. Симоненко, К.А. Литвинцева // Дальневосточный медицинский журнал. - 2015. - №1. - С. 20-23.

5. Мадаминов, А.М. К вопросу хирургического лечения тромбированного геморроя II-III степени / А.М. Мадаминов, М.М. Малькави, А.Ю. Айсаев // Вестник Кыргызскороссийского славянского университета. - 2017. - Т.17, №7. - С. 44-46.

6. К.В. Пучков, В.В. Иванов. Технология дозированного лигирующего электротермического воздействия на этапах лапароскопических операций: монография, - М.: ИД МЕДПРАКТИКА, 2005. - 176 с.

\section{СУДЬБА ВОЕННОГО ХИРУРГА ПРОФЕССОРА В.А.ЕМЕЛЬЯНОВА КАК ПРИМЕР СЛУЖЕНИЯ ЛЮДЯМ}

Теремов Д.Д., Нагорная С.В.

\section{Тверской государственный медицинский университет}

\section{Смоленский государственный медицинский университет}

Цель: изучить биографию профессора В.А.Емельянова и оценить его вклад в советскую военную медицину. 
Методы исследования. При выполнении работы были использованы историкогенетический и проблемно-хронологический методы исследования, изучены материалы Архива Смоленского государственного медицинского университета (СГМУ), фонды Музея СгМу.

Результаты. Владимир Афанасьевич Емельянов родился 28 августа 1913 г. в д.Старая Липовка Смоленской губернии. В 1931 г. поступил в Смоленский государственный медицинский институт (СГМИ), который окончил с отличием в 1936 г.. По окончании института был оставлен в ординатуре при кафедре госпитальной хирургии СГМИ. В 19381939 гг. работал ассистентом кафедры общей хирургии, а в 1939 г. перешел на кафедру госпитальной хирургии СгМИ, где работал до начала Великой Отечественной войны.

23 июня 1941 г. В.А.Емельянов был призван в ряды РККА и назначен главным хирургом 417-го медсанбата 331-ой стрелковой дивизии Западного фронта. Сам Владимир Афанасьевич вспоминал о суровых годах войны так: «С первого дня я был на передовой в боях. Сначала в медсанбате, участвовал в сражениях под Минском, под Москвой и Волоколамском, Ржевом и Вязьмой, Смоленском и Оршей. Дважды контузило. Однажды в бою под Сычевкой случилось такое, что запомнилось на всю жизнь. Шел большой наступательный бой. Я много часов был на ногах, оперировал почти непрерывно и боялся, что вот-вот от усталости свалюсь с ног. А тут как раз принесли раненого на носилках и както осторожно занесли в палату. Я сбросил с раненого солдата шинель и оторопел: в сильно опухшей ноге, глубоко врезавшись в икру и застряв в кости, торчала неразорвавшаяся минометная мина. Усталость, как ветром, сняло с меня. Оперировал я тогда, выставив из палаты весь персонал и раненых, за исключением помогавшей мне сестры. После боев под Оршей в начале 1944 г. я был направлен на выполнение особого задания - оказывать помощь Югославской народно-освободительной армии в развертывании и налаживании работы военно-полевой медицинской службы. Самолетом с группой товарищей был заброшен в глухой горный район Югославии, сразу попав в необычные для меня условия партизанской войны, где фронт возникал неожиданно и зачастую там, где его не ждали. Сначала меня назначили главным хирургом партизанского корпуса, а затем на ту же должность во 2-ю Югославскую армию, которая объединяла армейские и партизанские части. Нужно было и самому оперировать раненых, порой со сложными ранениями, в условиях непрекращающегося кругового боя. Помогали югославские врачи. Однажды удалось спасти жизнь и вернуть в строй одного из видных деятелей Коммунистической Партии Югославии, сподвижника Иосипа Броз Тито, совсем еще молодого Цвиетина Миятовича». В 1942 г. вступил в ВКП(б). За образцовый труд при выполнении заданий Родины В.А.Емельянов был награжден двумя орденами Красной Звезды (1942,1943), орденами Отечественной войны І-ой (1986) II-ой (1944) степени и медалями СССР, а также орденом «За заслуги перед народом Югославии» II-ой степени.

В сентябре 1945 г. Владимир Афанасьевич Емельянов был демобилизован из армии в звании майора медицинской службы и приступил к исполнению обязанностей ассистента кафедры госпитальной хирургии СгМИ, одновременно работал главным врачом 2-ой 
Советской больницы г.Смоленска. В феврале 1948 г. защитил диссертацию на соискание ученой степени кандидата медицинских наук на тему «Оперативное лечение абдоминальных огнестрельных ранений». В 1951-1968 гг. работал доцентом кафедры. В 1952-1954 гг. был командирован в Китайскую Народную Республику на должности главного хирурга правительственной больницы в Пекине. В 1968-1984 гг. возглавлял кафедру травматологии и ортопедии с курсом военно-полевой хирургии. В 1969 г. защитил диссертацию на соискание ученой степени доктора медицинских наук на тему «Резекция легких при туберкулезе». В 1970 г. доцент В.А.Емельянов был награжден знаком «Отличник здравоохранения» и утвержден в звании профессора. Был основателем и на протяжении многих лет (1968-1985 гг.) бессменным председателем Смоленского областного научного общества ортопедов и травматологов. В 1984-1986 гг. работал профессором-консультантом кафедры травматологии и ортопедии с курсом военно-полевой хирургии Смоленского государственного медицинского института.

Владимир Афанасьевич Емельянов ушел из жизни 8 ноября 1997 г., оставив добрую память в сердцах коллег, учеников и благодарных пациентов.

Известный полководец, маршал Советского Союза Иван Христофорович Баграмян, после завершения войны писал: «То, что сделано советской военной медициной в годы минувшей войны, по всей справедливости может быть названо подвигом. Для нас, ветеранов Великой Отечественной войны, образ военного медика останется олицетворением высокого гуманизма и мужества». Неоценим вклад медиков в дело Победы. Небывалый по своим масштабам повседневный массовый героизм, беззаветная преданность Родине, лучшие человеческие и профессиональные качества были проявлены ими в дни суровых испытаний. Самоотверженный, благородный труд их возвращал жизнь и здоровье раненым и больным, помогал вновь занять свое место в боевом строю, восполнял потери, помогал сохранять на должном уровне численность Советской армии. Владимир Афанасьевич Емельянов своим трудом в годы войны вернул в строй сотни раненых солдат и офицеров, а в послевоенные годы - сохранил и возвратил здоровье многим нашим соотечественникам. Жизненный путь профессора, доктора медицинских наук В.А. Емельянова является примером стойкости и гуманизма для многих поколений как молодых врачей, так и состоявшихся специалистов.

\section{Список литературы.}

1. Архив СГМУ. - Ф.3284. - Оп.1с. - Д. 172. - С.1-152. - Личное дело Емельянова В.А.

2. Музей СГМУ. Фонд профессора, доктора медицинских наук Емельянова В.А.

3. Стариков Г.М. Смоленский государственный медицинский институт (1920-1967). Смоленск, 1967. - 158 с. 


\section{ТОПОГРАФО-АНАТОМИЧЕСКИЕ ПРЕДПОСЫЛКИ К РАЗРАБОТКЕ СПОСОБОВ ГЕМОСТАЗА НА СЕЛЕЗЁНКЕ}

Рагимов Г.С., Рагимова Р.И.

\section{Дагестанский государственный медицинский университет}

Актуальность. В абдоминальной хирургии открытые и закрытые травмы селезёнки отличаются тяжелой кровопотерей и занимают одно из ведущих мест среди повреждений органов брюшной полости $[1,2,6,8]$. По данным различных авторов, частота повреждений селезёнки составляет от 12 до 50\% [3,4,7]. Для разработки органосохраняющих операций на селезёнке необходимо изучение закономерностей внутриорганных разветвлений сосудов, толщину и прочность капсулы органа $[4,5,9]$. Толщина капсулы паренхиматозных органов является одним из важных факторов, обеспечивающих прочность наложенных швов при резекциях и ушиваниях повреждений. Цель: изучить топографо-анатомические особенности селезёнки для разработки органосохраняющих операций.

Материал и методы исследования. Исследования выполнены на 50 препаратах селезёнки, взятых от трупов людей обоего пола в возрасте от 25 до 65 лет. Изучали закономерности внутриорганных разветвлений сосудов селезёнки, гистотопографию и прочностные характеристики капсуллярного аппарата органа. Архитектонику внутриорганных сосудов селезёнки исследо-вали методом рентгеновазографии. В качестве контрастной массы использо-вали раствор свинцового сурика на скипидаре, который готовили перед заполнением сосудов. Рентгеновские снимки делались с помощью рентгенов-ского аппарата РУМ-4.Толщину капсулы селезёнки исследовали методом мор-фометрии по 10 свежих нефиксированных препаратов селезёнки. Брали кусоч-ки ткани селезёнки с различных участков органа. Изготовленные срезы изучали под микроскопом МБС-10 со специальной шкалой - сетки для определения толщины отдельных структур органа. Прочность капсулы органов исследовали с помощью специально разработанного устройства. Суть способа заключается в следующем: прокалывая фиброзную капсулу органа на одинаковых расстояниях на 0,5 см; 1,0 см; 1,5 cм; 2,0 см от края раны (продольные, поперечные) на диафрагмальной и висцеральной поверхностях с помощью съёмной конструкции, осуществляли тягу перпендикулярно к ране. Показатель прочности капсулы (в у.е.) определяли по фиксированному значению на шкале в момент начала прорезывания.

Результаты исследований. Исследования

внутриорганной артериальной сети селезёнки показали, что внутриорганные сосуды селезёнки в 85\% случаев имеют поперечное направление к длинной оси органа. Межзональные и межсегментарные границы органа в виде хорошо выраженных борозд на его диафрагмальной поверхности идут под острыми углами по отношению к длинной оси органа в пределах от 55 до 80 градусов. По нашим данным, между зонами имеются «малососудистые» участки, которые соответствуют внешним ориентирам - вырезкам органа, что встречаются у людей в 69,7\%. Вырезки органа во 
всех случаях соответствовали началу «малососудистых» участков. Они ориентированы преимущественно поперечно к длинной оси органа. Морфометрические данные по изучению толщины капсулы селезёнки человека показали, что она неодинакова на разных участках. Так, на диафраг-мальной поверхности у нижнего полюса селезёнки она

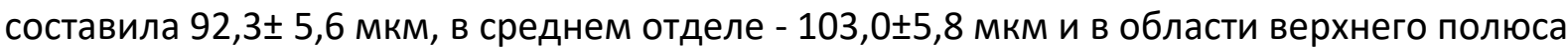
составила 99,8 7,6 мкм. На висцеральной поверхности селезёнки наибольшую толщину

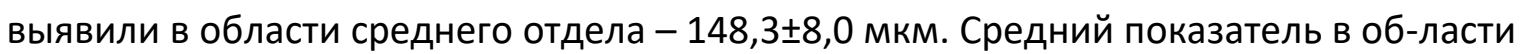

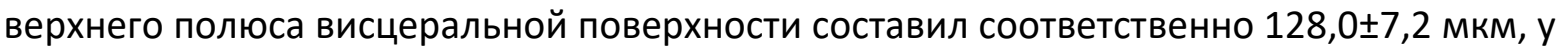
нижнего - 125,4ะ6,4 мкм.

Таким образом, толщина капсулы на диафрагмальной поверхности селезёнки человека достоверно меньше, чем на висцеральной, у верхнего полюса толще, чем у нижнего, но тоньше, чем у среднего отдела, и наибольшую толщину имеет средний отдел.

Изучение прочности капсулы селезёнки человека при продольных ранах диафрагмальной поверхности в области верхнего полюса выявило следующие данные: при захватывании

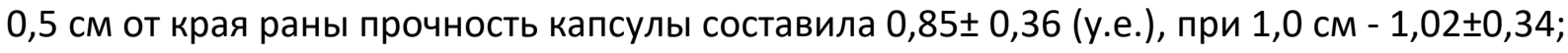

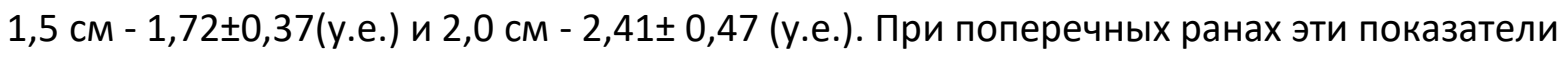

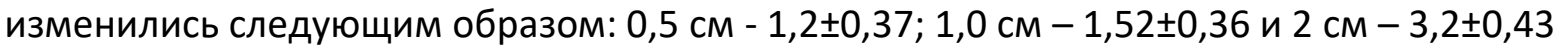
(у.е.). На висце-ральной поверхности в области верхнего полюса селезёнки прочность

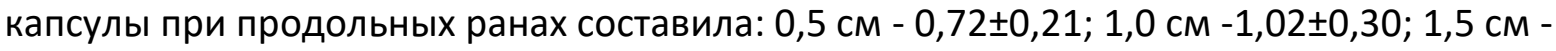

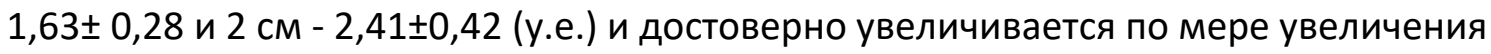
расстояния захватываемой капсулы от края раны органа, кроме в случае захватывания 0,5 cм $(p \geq 0,05)$. Те же исследования при поперечных ранах на висцеральной поверхности соответствовали $0,5 \mathrm{~cm}-1,21 \pm 0,38 ; 1,0 \mathrm{~cm}-1,75 \pm 0,41 ; 1,5 \mathrm{~cm}-2,51 \pm 0,28 ;$ и $2 \mathrm{~cm}-3,38 \pm 0,35$ (y.e.).

Те же исследования на диафрагмальной поверхности в области среднего отдела селезёнки при продольных ранах соответствовали: 0,5 cм - 0,81 +0,23 (у.е), а наибольшую

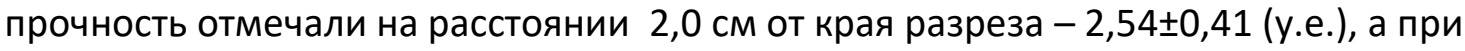

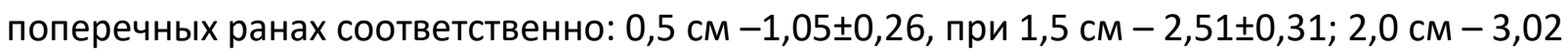
$\pm 0,28$ (у.е.). Выявили значимое увеличение $(p \leq 0,05)$ прочности капсулы, по мере увеличения расстояния захватываемой капсу-лы от края раны. Прочность капсулы при продольных и поперечных ранах увеличивается статистически значимо по мере увеличения расстояния захваты-ваемой капсулы $(1,0 ; 1,5 ; 2,0$ см) от края раны. А при поперечных ранах в области средней трети селезёнки прочность капсулы составила: 0,5

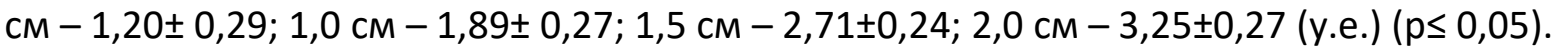

И так, при поперечных ранах прочность капсулы на диафрагмальной и вис-церальной поверхности средней трети селезёнки значительно и статистически значимо выше в случаях захвата капсулы на расстоянии от края раны $(1,0 \mathrm{~cm}, 1,5 \mathrm{~cm}, 2,0 \mathrm{~cm})$ и более чем при ранах имеющих продольное направление.

При исследовании прочность в области нижнего полюса органа выявили аналогичные данные. Прочность капсулы при поперечных ранах на диафраг-мальной и висцеральной 
поверхностях селезёнки значительно выше при захватывании от края раны 1,0 cм и больше ( $\leq 0,05)$,чем при ранах, имеющих продольное направление, как следствие, более устойчива к прорезыванию, что следует учесть при ушивании ран.

Заключение. Изучением хирургической анатомии капсулы селезёнки установлено, что толщина капсулы селезёнки на диафрагмальной поверхности меньше, чем на висцеральной поверхности; у верхнего полюса толще, чем у нижнего, но тоньше, чем у среднего отдела. Прочность капсулы при поперечных ранах на диафрагмальной и висцеральной поверхностях селезёнки значительно выше при захватывании от края раны на 1,0 см и более чем при ранах, имеющих продольное направление. Раны селезёнки, расположенные поперечно, более устойчивы к прорезыванию по сравнению с продольными ранами. В связи с этим при секторальной резекции селезёнки разрез следует проводить в поперечном направлении, что обеспечивает надежность её ушивания. Учет выявленных особенностей строения капсул селезёнки позволяет исключить прорезывание швов и тем самым улучшить результаты органосохраняющих операций на селезёнке.

\section{Список литературы.}

1. Алексеев, В.С. Клинико-анатомическое обоснование органосохраняющих операций при повреждениях селезенки (клинико-экспериментальное исследова-ние):автореф. дисс... канд. мед.наук.- Саранск, 1997.- 18с.

2. Бежин А.И. Юбилей кружка кафедры оперативной хирургии и топографической анатомии // Innova. - 2017. - №8 (3). - С. 6-8.

3. Гланц, Р.М. Сберегательная хирургия поврежденной селезенки / Р.М. Гланц,

М.М. Рожинский.- М.:Медицина, 1973. - 103 с.

4. Липатов В.А., Северинов Д.А., Саакян А.Р. Локальные гемостатики в хирургии ххі века (обзор литературы)// 2019.- №1 (14).- С.16-22

5. Орлов, М.Н. Топографо-анатомические ориентиры для резекции травмиро-ванной селезенки у детей / М.Н. Орлов //Теория и практика прикладных анатоми-

ческих исследований в хирургии. Материалы Всероссийской научной конферен-ции (12-13 октября). - СПб, 2001.- С.103-104.

6. Рагимов, Г.С. Резекция селезенки (экспериментальное исследование): дисс. ...канд. мед.наук. - Махачкала, 1994. - 153 с.

7. Сорокина, А.П. Клиническая морфология селезёнки / А.П. Сорокина, Н.Я. Полянкин, Я.И. Федонюк. - М.: Медицина, 1989. -155с. 
8. Guillon F., Borie F., Millat B. Spleen trauma //J. Chir. (Paris). - 2000. - Vol. 137. - N 4. - P. 205213.

8. McIntyre L.K., Schiff M., Jurkovich G.J. Failure of nonoperative management of splenic injures: causes and conseguences //Arch. Surg. - 2005. - Vol. 140. - N 6. - P. 565 - 568; discussion 568-589.

9. Mahon P.A., Sutton J.E. Nonoperative management of adults splenic injury due to blunt trauma. A warning //Amer. J. Surg. - 1985. - Vol. 149. - N 6. - P. 716-721.

\section{ТРУДНЫЕ ВОПРОСЫ МОДЕРНИЗАЦИИ НЕПРЕРЫВНОГО МЕДИЦИНСКОГО ОБРАЗОВАНИЯ ХИРУРГИЧЕСКИХ СПЕЦИАЛЬНОСТЕЙ}

Григорьев Н.Н., Бондарев Г.А., Бобровская Е.А., Кононенко К.В.

Курский государственный медицинский университет

В настоящее время отчетливо прослеживаются изменения подготовки врачей-хирургов, их постдипломного обучения, что вызывает неоднозначные тенденции.

Обучение хирургическому мастерству имеет многовековую историю. Российские национальные программы преподавания хирургии во многом обязана великому ученому, мыслителю и педагогу Н.И. Пирогову, который ратовал за создание хирургических клиник, акцентировал внимание на практической подготовке специалистов.

Основополагающий принцип преподавания хирургии «у постели больного», заложенный Н.И. Пироговым, был сохранен и стал основой русской системы обучения врачеванию, которая предусматривает три ступени: «общая хирургия», «факультетская хирургия» и «госпитальная хирургия». Мировое признание российской высшей медицинской школы до недавнего времени было связано, прежде всего, с хорошей практической подготовкой специалистов благодаря многоуровнему обучению [2].

Однако исключение из программы образования врачей хирургических специальностей субординатуры, интернатуры начало проявляться сужением возможностей совершенствования практической подготовки, как на этапе обучения, так и в последипломном образовании.

Трудно не согласиться с суждением академика М.А. Пальцева о том, что основной недостаток подготовки врачей связан с неадекватностью полученных знаний, навыков и умений к реальным потребностям практического здравоохранения. 
Современные медицинские технологии, с одной стороны, увеличивают возможности диагностики и лечения больного, а с другой стороны - способствуют снижению практического опыта врачей, возникновению их некоммуникабельности, дистанциируют врачей от больного [1].

Настоящие программы обучения в медицинских вузах часто акцентированы на пополнение теоретических знаний, достижений современных инструментальных технологий, а не на улучшение умений грамотного физикального обследования больного, критическое осмысление собранной информации, создание рационального плана лечения. Все это ослабляет связь пациента с врачом.

Также в последние годы наблюдается снижение притока молодых кадров в такую сферу медицины, как хирургия, требующая длительного и напряженного обучения и не всегда гарантирующая молодым специалистам достойное материальное вознаграждение.

Одной из особенностей подготовки специалистов по хирургии является тот факт, что обучение оперативному мастерству подразумевает индивидуальную передачу мануальных навыков и хирургических технологий, т.е. подготовка и усовершенствование специалистов хирургического профиля - это «штучная работа». Роль педагогов - хирургов с большим практическим стажем, уважаемых в медицинской среде специалистов, является одним из главных мотивов, следуя которому молодые врачи стремятся быть похожими на своих наставников [3, 4].

Таким образом, обучение хирургии должно иметь максимальную практическую направленность и проводиться в крупных многопрактических клиниках.

Дистанционное обучение, как новая технология, со временем займет свою нишу в программе обучения хирургией, но оно не должно довлеть над практической составляющей подготовки врача-хирурга.

Рациональное сочетание практических и мануальных технологий, научно-технического прогресса, применительно к обучению врачей хирургических специальностей должно стать актуальной задачей современного этапа модернизации медицинского образования.

\section{Список литературы.}

1. Григорьев Н.Н., Бобровская Е.А., Григорьев С.Н. Актуальные вопросы технологии обучения хирургии // Современные проблемы науки и образования. - 2016. - № 4.; URL: http://science-education.ru/ru/article/view?id=24912 (дата обращения: 19.09.2019).

2. Совцов С.А., Федоров А.В., Таривердиев М.Л. Непрерывное медицинское образование врачей хирургических специальностей // Хирургия. - 2014. - № 2. - С. 42-49. 
3. Ходжаян А.Б., Агранович Н.В. Особенности организации эффективной самообразовательной деятельности студентов в медицинском вузе // Фундаментальные исследования. - 2011. - № 11.- 1. - С.149-153.

4. Шпаковская Л.Л. Политика высшего образования в Европе и России. - СПб.: Норма, 2007. -328 c.

\title{
ЭКСПЕРИМЕНТАЛЬНОЕ ОБОСНОВАНИЕ ВЫБОРА ШОВНОГО МАТЕРИАЛА ДЛЯ ОПЕРАЦИЙ НА ПЕЧЕНИ С УЧЕТОМ ЕГО ФИЗИКО- МЕХАНИЧЕСКИХ СВОЙСТВ
}

\author{
Липатов В.А., Денисов А.А., Трофимов И.В.
}

\section{Курский государственный медицинский университет Минздрава РФ, Курск, Россия}

Травма печени - одно из наиболее опасных для жизни пациента абдоминальных повреждений, сопровождающееся массивным кровотечением. В настоящее время наиболее популярным методом остановки кровотечения является лигирование кровоточащих сосудов, при этом выбор шовного материала несет эмпирический характер [1-3]. Цель работы: провести оценку физико-механических характеристик шовного материала в зависимости от его структуры. Материалы и методы. Исследование проведено в лаборатории экспериментальной хирургии и онкологии НИИ экспериментальной медицины КГМУ. Объектом исследования являлись участки диафрагмальной поверхности правой доли печени трупов мужского пола в возрасте 35-40 лет, изъятых в ОБУЗ «Бюро СМЭ» г. Курска, не имеющих макроскопических патологических изменений и заболеваний печени в катамнезе. Выделяли участок паренхимы органа размерами 7,5×7×4 cм. Затем, на нем наносилась рана длиной $3 \mathrm{~cm} \mathrm{и}$ глубиной 2 см, которую ушивали узловым швом, но не затягивали, а накладывали один простой полуузел. Для лигирования использовали отрезки шовного материала длиной 50 см и равной толщины (3/0 по USP). При этом использовали монофиламентные (Кетгут), крученые (Капрон) и плетеные (ПГА) нити. После лигирования раны исследуемый участок органа помещали на устройство для исследования физико-механических характеристик швов и шовного материала, степени деформации паренхимы органа (патент №184617) [4], которое размещали на РЭМ-0,2-1. При этом обращали внимание на максимальное усилие (Fmax) до прорезывания паренхимы органа, а также степень вытяжения нити (Lu). Были сформированы 3 группы согласно структуре используемого шовного материала по 60 образцов. Затем вычислялись M (выборочное среднее) Fmax и Lu. B результате проведенного исследования были получены следующие результаты: Монофиламентный шовный материал M Fmax (H) = 51,2; M Lu (Mм) = 54,31; Крученый шовный материал M $F \max (H)=88,68 ; M ~ L u(M M)=73,13 ;$ Плетеный шовный материал M Fmax $(H)=84,01 ; M ~ L u$ $($ мм $)=70,56$. Заключение. Таким образом, в результате исследования стало очевидно, что 
монофиламентный шовный материал нецелесообразно применять при операциях на печени, поскольку Fmax при прорезывании паренхимы равен 51,2 H, когда как крученые и плетеные хирургические нити показали значимые результаты 88,68 H и 84,01 H.

\section{Список литературы.}

1. Пахвелян В.Г. Гемостаз в хирургии паренхиматозных органов брюшной полости. Обзор литературы / В.Г. Пахвелян, С.А. Колесников // Вестник хирургической гастроэнтерологии.- 2015.- №1-2.- С. 50-56.

2. Северинов Д.А. Швы паренхиматозных органов: преимущества и недостатки/ Д.А. Северинов [и др.]// В сборнике: Проблемы гемостаза в хирургии XXI века. Сборник трудов университетской конференции студентов и молодых ученых. Лазаренко В.А., Липатов В.А., Лазаренко С.В.- 2017.- С. 17-20.

3. Семичев Е.В. Особенности печени после гемостаза классическим швом на ранние сроки (экспериментальная работа) / Е.В. Семичев [и др.]// Сибирский медицинский журнал. - 2014.- Том 130. - №7. - С. 32-36.

4. Патент РФ 2018124409, 03.07.2018. Устройство для исследования физико-механических характеристик швов и шовного материала, степени деформации паренхимы органов// Патент России № 184617U1. 2018. / Лазаренко В.А., Липатов В.А., Лазаренко С.В. и др.

\section{ЭКСПРЕССИЯ PGRMС1 И GALECTIN-1 ПАРЕНХИМАТОЗНЫМ КОМПОНЕНТОМ ЭНДОМЕТРИОИДНОЙ АДЕНОКАРЦИНОМОЙ ЭНДОМЕТРИЯ ПРИ ВОЗДЕЙСТВИИ ПРЕДОПЕРАЦИОННОЙ ГАММА- ЛУЧЕВОЙ ТЕРАПИЕЙ \\ Дмитрий Александрович Зиновкин \\ УО "Гомельский государственный медицинский университет", г. Гомель, Республика Беларусь}

Актуальность. Мембранный компонент 1 рецептора прогестерона (сокращенно PGRMC1) представляет собой белок, который соединяется с белками, связывающими прогестерон, в печени и яичнике. У людей белок PGRMC1 кодируется геном PGRMC1. Экспрессия PGRMC1 резко увеличивается в опухолях молочной железы и в линиях клеток рака толстой кишки, щитовидной железы, яичника, легкого и шейки матки. [1]

Galectin-1 - белок, кодируемый геном LGALS1, обычно чрезмерно экспрессируется при агрессивном течении злокачественных новообразований различных локализаций, опосредовано регулирует клеточные процессы при прогрессии рака. Galectin-1 регулирует 
клеточную агрегацию, миграцию и инвазию, опухолевый ангиогенез и апоптоз Т-клеток. [2]

На сегодняшний день модуляция опухолевого микроокружения ионизирующим излучением открывает новые перспективы в изучении биологии рака.

Целью данного исследования было выявление особенностей экспрессии PGRMC1 и Galectin-1 паренхимой эндометриоидной аденокарциномы тела матки подвергшегося воздействию предоперационому гамма-облучению в дозе 13,5 Гр.

Материалы и методы. Собранный и проанализированный архивный гистологический материал 80 пациенток для исследования был разделен на две группы: пациентки, подвергшиеся лучевой терапии (42 случая) и группа пациенток без лучевой терапии (38 случаев). Иммуногистохимическое окрашивание производилось по стандартной методике, визуализация антител производилось с использованием DAB, контрокрашивание производилось гематоксилином Майера. Измерения производились в 10 неперекрывающихся полях зрения при увеличении $\times 400$. Экспрессия оценивалась отдельно в паренхиме. Для статистического анализа использовался тест Манна-Уитни, Анализ проводился с использованием пакета программ Statistica 9.0 За уровень статистической значимости принимался $p<0,05$

Результаты. Экспрессия PGRMC1 в паренхиматозном компоненте у пациенток облученной группы составила 30,1\% (18,6-40,3\%), в группе без облучения - 59,9\% (47,7-69,8\%). При сравнении групп по представленному показателю были выявлены статистически значимые различия ( $<<0,001)$. Исследования показывают, что PGRMC1 экспрессируется при ранней стадии рака яичников, и его экспрессия увеличивается на более поздних стадиях. Кроме того, PGRMC1 обнаруживается практически в каждой раковой клетке яичника, независимо от стадии опухоли. [3]

Медиана паренхиматозной экспрессии Galectin-1 в случаях ЭА с облучением составила 49,5\% (43,5-65,6\%). В группе без облучения-67,8\% (56,7-80,7\%). При сравнении групп по данному показателю отмечались статистически значимые различия $(p<0,001)$. Экспрессия Galectin-1 увеличивается в различных типах злокачественных новообразований, включающих меланому, рак яичников, легких, простаты, мочевого пузыря, щитовидной и поджелудочную железы, шейки матки, в ряде случаев за счет паренхиматозного компонента. [2]

Таким образом, статистически значимое снижение экспрессии Galectin-1 и PGRMC1 при воздействии на эндометриоидную аденокарциному тела матки позволяет предположить дополнительные, не связанные с непосредственным разрывом нитей ДНК, механизмы воздействия лучевой терапии на опухоль.

Заключение. Полученные данные указывают на подавление секреции PGRMC1 и Galectin1 в паренхиматозном компоненте опухоли при действии гамма-облучения, что может являться проявления специфического модифицирующего эффекта на опухолевое микроокружение эндометриоидной аденокарциномы тела матки. 


\section{Список литературы.}

1. Crudden G. Overexpression of the cytochrome $\mathrm{p} 450$ activator hpr6 (heme-1 domain protein/human progesterone receptor) in tumors. / Crudden G, Loesel R, Craven RJ // Tumour Biology. - 2005. - 26 (3). - 142-6.

2. Cousin JM. The Role of Galectin-1 in Cancer Progression, and Synthetic Multivalent Systems for the Study of Galectin-1. / Cousin JM, Cloninger MJ // International Journal of Molecular Sciences. - 2016. - 17(9). - 1566.

3. John J. Peluso. Regulation of Ovarian Cancer Cell Viability and Sensitivity to Cisplatin by Progesterone Receptor Membrane Component-1 / John J. Peluso, Xiufang Liu, M. Melinda Saunders // The Journal of Clinical Endocrinology \& Metabolism. - 2008. - 93 (5). - 1592-1599. 
ФОТОМАТЕРИАЛЫ

Кузнецов Д.А.
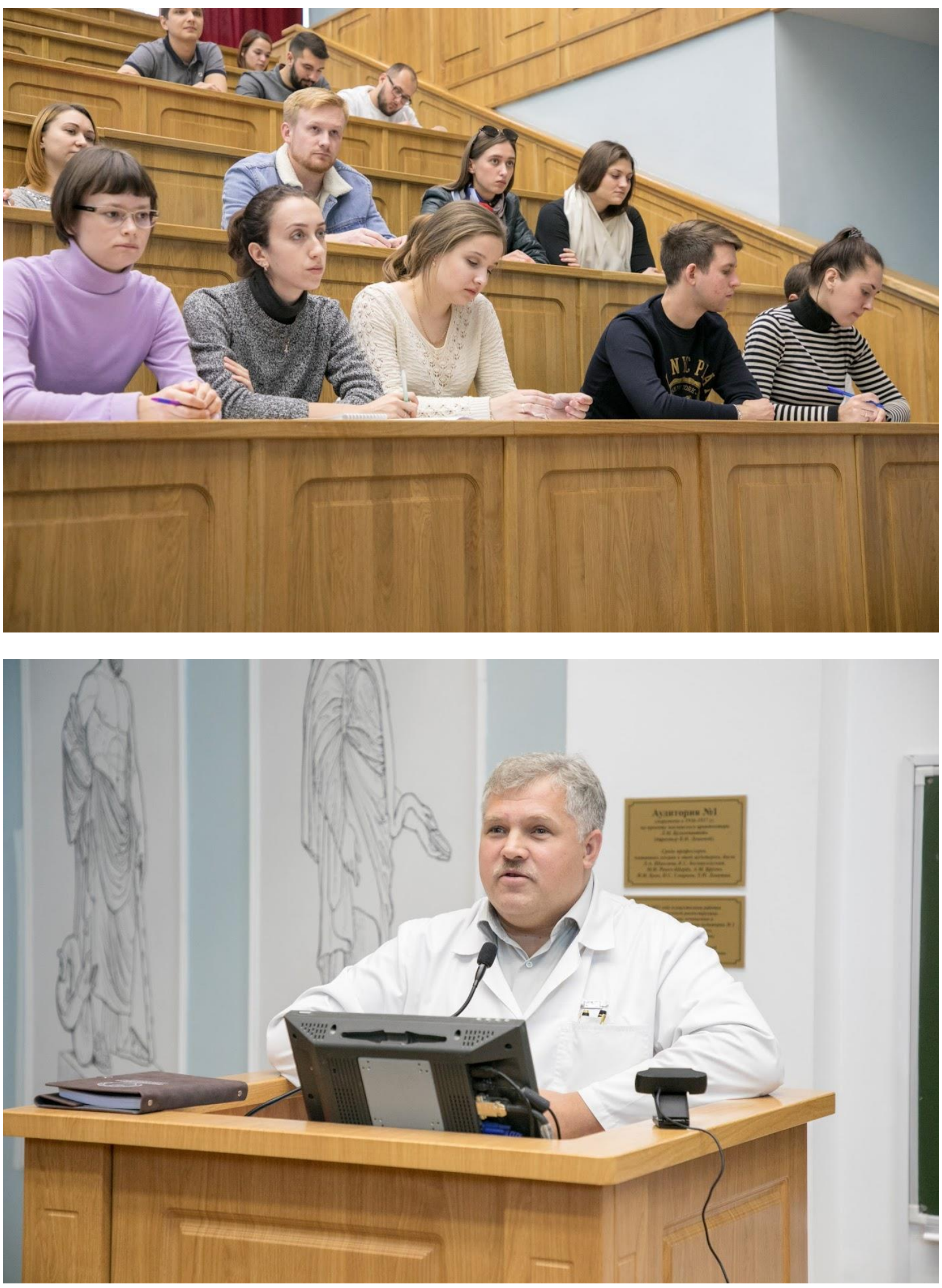

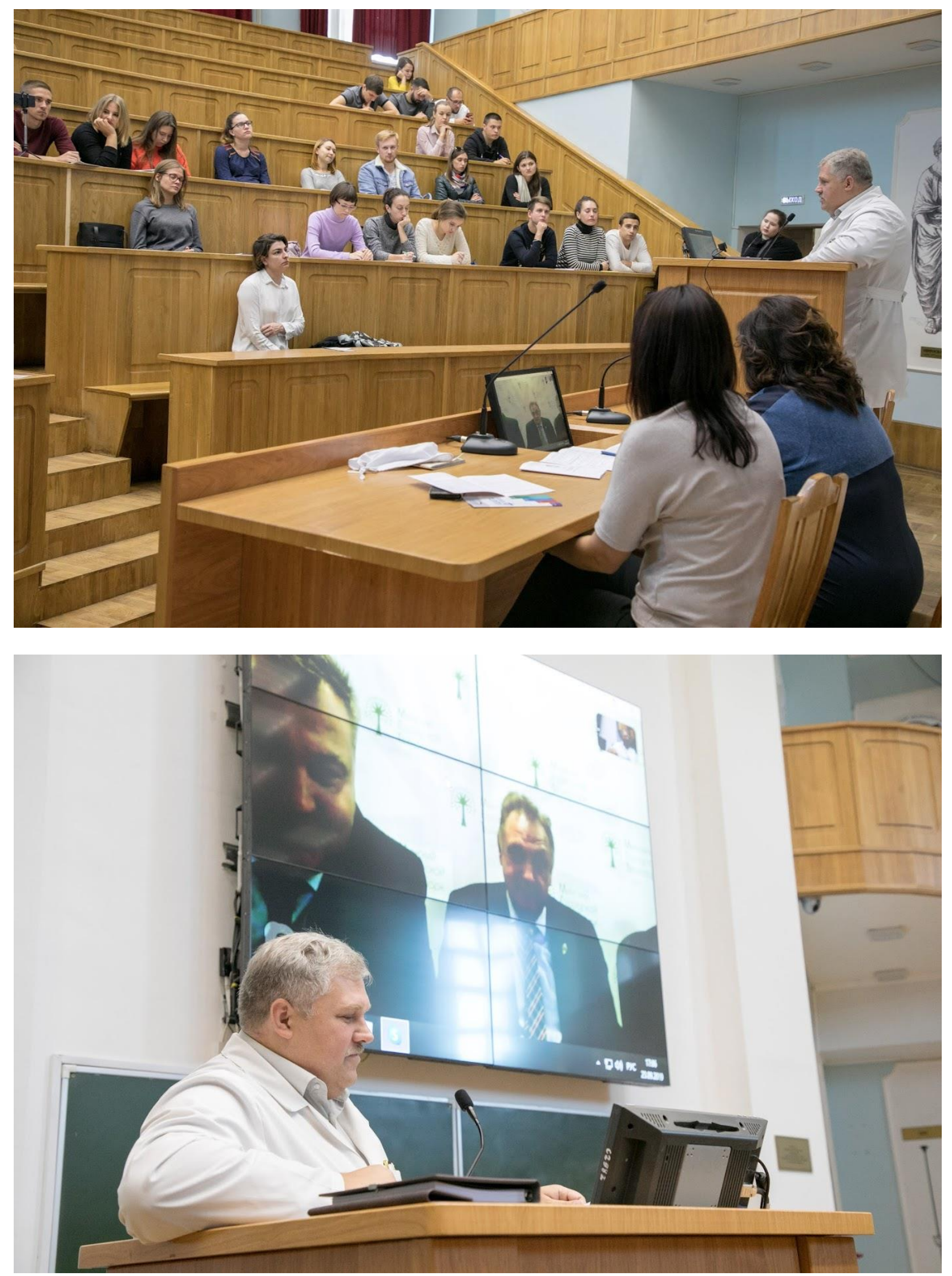

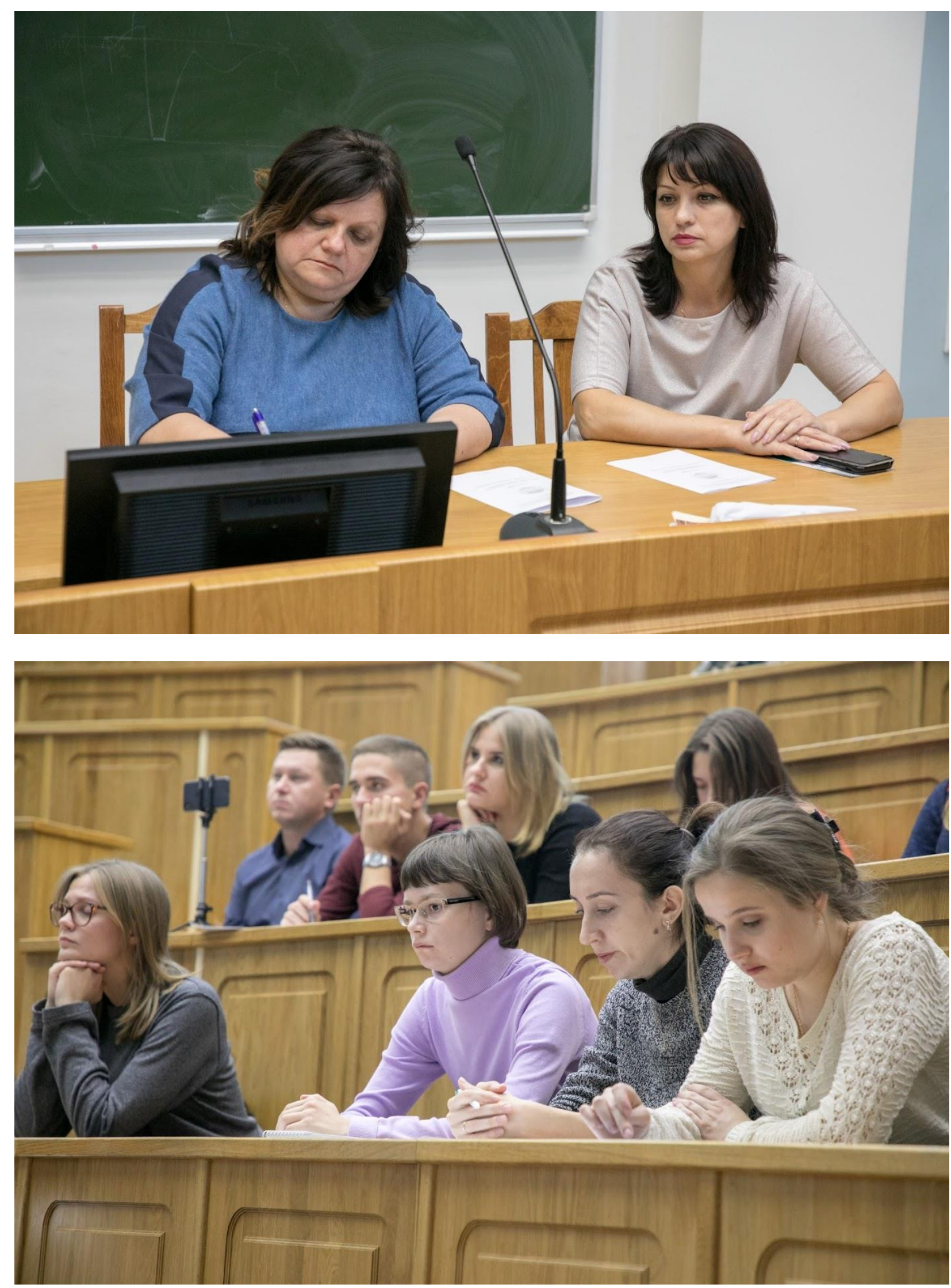

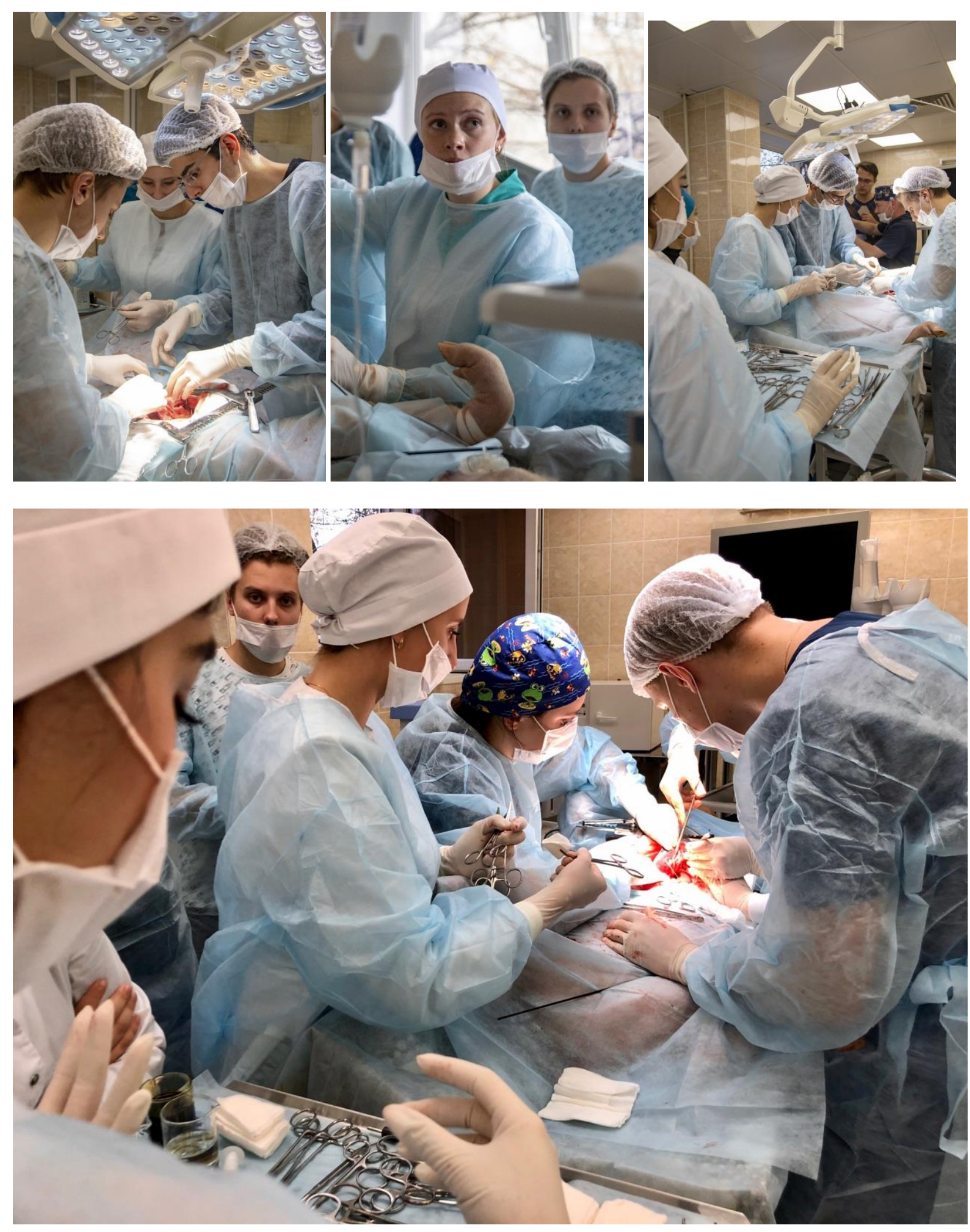


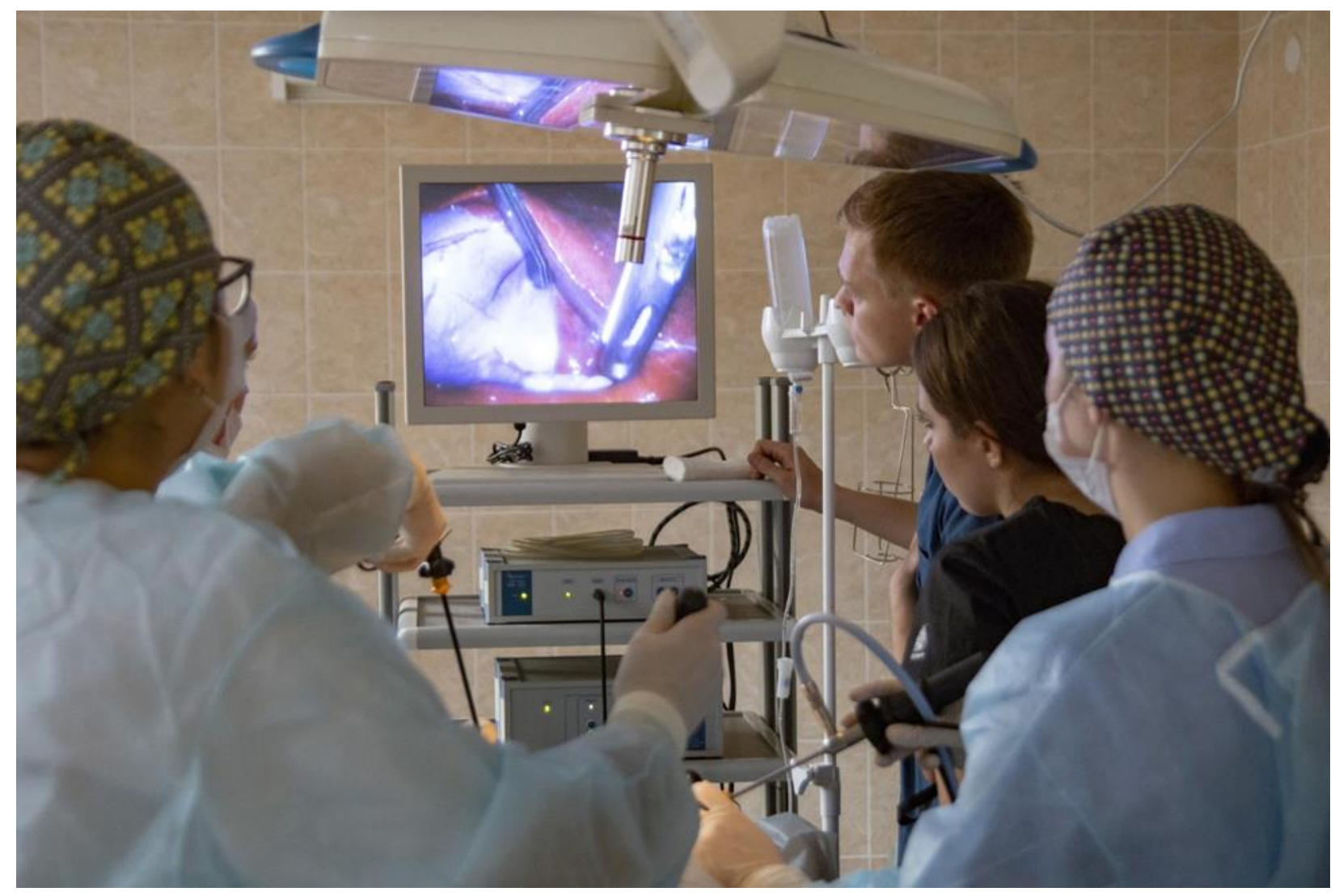




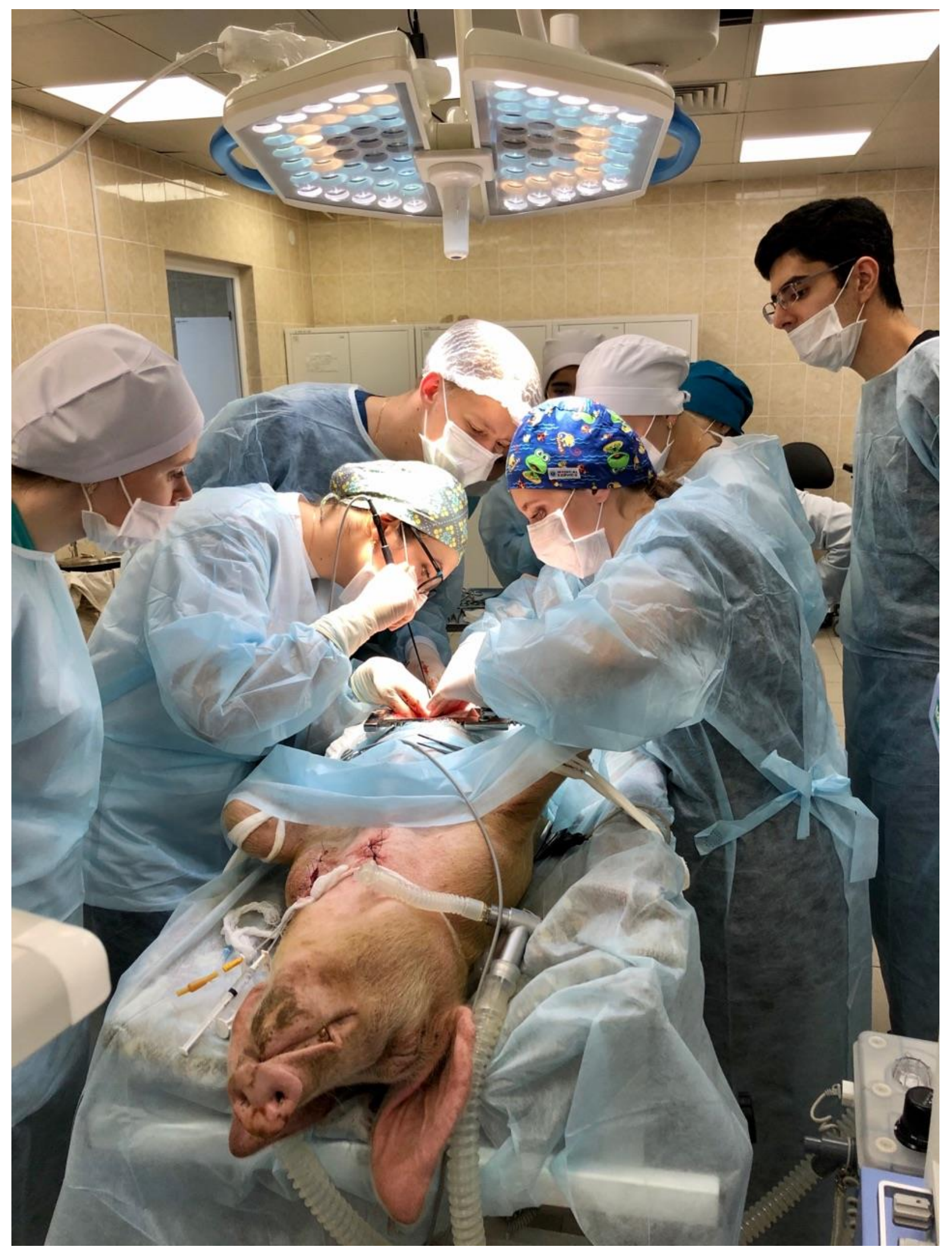

